\title{
LETTERS TO JMG
}

\section{Alterations of the Birt-Hogg-Dubé gene $(B H D)$ in sporadic colorectal tumours}

\author{
K Kahnoski, S K Khoo, N T Nassif, J Chen, G P Lobo, E Segelov, B T Teh
}

J Med Genet 2003;40:511-515

C olorectal cancer (CRC) is the third most common cancer diagnosed in both men and women, and the second most common cause of cancer deaths in the United States. There were approximately 150000 new cases resulting in 57000 deaths in $2002 .{ }^{1}$ CRC is one of the most studied cancer types and its underlying aetiology best elucidated. Colorectal tumorigenesis involves a multistep process including genetic and epigenetic alterations of numerous CRC related genes that may act as either oncogenes or tumour suppressor genes. ${ }^{2-5}$ The majority of sporadic CRCs are characterised by deletions of large chromosomal segments, which are thought to represent the loss of wild type tumour suppressor genes. ${ }^{67}$ About $15 \%$ of sporadic CRCs, on the other hand, show microsatellite instability (MSI), characterised by the insertion and/or deletion of simple repeat sequences and indicative of the involvement of defective mismatch repair. ${ }^{89}$

Birt-Hogg-Dubé syndrome (BHD, OMIM 135150) is an inherited autosomal dominant syndrome characterised by a triad of cutaneous lesions consisting of fibrofolliculomas,

\section{Key points}

- A high incidence of colorectal tumours was recently reported in patients with Birt-Hogg-Dubé syndrome (BHD), implicating a potential role for the $B H D$ gene in colorectal tumorigenesis.

- We have screened the BHD gene for genetic (mutations and loss of heterozygosity $(\mathrm{LOH})$ ) and epigenetic (altered promoter methylation status) alterations in 47 unselected primary sporadic colorectal tumours (10 polyps and 37 carcinomas). One polyp and seven carcinomas showed microsatellite instability (MSI) while all other tumours were microsatellite stable (MSS).

- We identified two novel missense mutations, S79W and A445T, in two MSS carcinomas. Methylation status, examined by methylation specific PCR (MSP) analysis of 23 matched normal/carcinoma tissues, showed an absence of any BHD promoter methylation differences.

- Genotyping of microsatellite markers encompassing the BHD gene showed $\mathrm{LOH}$ in four of $10(40 \%)$ polyps and 29 of $36(81 \%)$ carcinomas. All four colon polyps showing $\mathrm{LOH}$ showed chromosomal loss in the corresponding carcinomas from the same patients. However, $\mathrm{LOH}$ was also present in the corresponding carcinomas of six other polyps that did not show $\mathrm{LOH}$, suggesting the involvement of $\mathrm{LOH}$ in colorectal tumour progression.

- Our results suggest that the BHD gene is involved in the tumorigenesis of a subset of MSS sporadic colorectal carcinomas, and that allelic loss in the region close to the $B H D$ gene may play a role in colorectal tumour progression. trichodiscomas, and acrochordons. ${ }^{10}$ A wide spectrum of neoplastic and non-neoplastic features has been described in BHD patients, ${ }^{11}$ including diverse types of kidney tumours ${ }^{12-17}$ and spontaneous pneumothorax..$^{12-16}{ }^{18}$ BHD has also been reported to be associated with colonic polyposis and colorectal neoplasia, ${ }^{13} 19-22$ although a large study of 223 patients from 33 BHD families could not establish such a relation. ${ }^{23}$ We recently reported a high incidence of colorectal polyps and carcinomas in patients with confirmed $B H D$ germline mutations, indicating that the $B H D$ gene may be involved in colorectal tumorigenesis. ${ }^{13}$ The BHD gene has been mapped to chromosome subband $17 \mathrm{pl} 1.2^{12} 14$ and recently identified to encode a novel protein named follicullin. ${ }^{15}$ Based on the presence of inactivating $B H D$ mutations in BHD patients, and the detection of $\mathrm{LOH}$ in a significant proportion of BHD related tumours, the BHD gene was considered to be a tumour suppressor gene. A $44 \%$ frequency of frameshift mutations within a mononucleotide $(\mathrm{C})_{8}$ tract (nt 1733-1740) has been detected in BHD patients, ${ }^{15}$ and this repeat tract represents a $B H D$ mutational hot spot. ${ }^{13}{ }^{15}$ Other studies have reported the presence of frameshift mutations within intragenic mononucleotide tracts of the TGFBR2 and BAX genes in CRC cell lines and tumours with high level MSI. ${ }^{24}{ }^{25}$ The poly $C$ tract of the $B H D$ gene may therefore be a potential site of mutation in CRC characterised by MSI.

We have evaluated the role of the BHD gene in 47 unselected colorectal tumours ( 10 polyps and 37 carcinomas) by screening all coding exons of the BHD gene for mutations and analysing 46 of the tumours for $\mathrm{LOH}$ in the chromosome region surrounding the BHD locus. Furthermore, alterations in $B H D$ promoter methylation profiles were determined in 23 cases of matched normal/carcinoma tissues where a sufficient quantity of DNA was available. We report the detection of two novel somatic missense mutations of the BHD gene and $\mathrm{LOH}$ in $81 \%$ of primary sporadic colorectal tumours with no change in promoter methylation profile. All mutations were detected in MSS tumours.

\section{MATERIALS AND METHODS}

\section{Tissue samples and DNA extraction}

Forty-seven matched samples (from 37 patients), of which 10 were colonic polyps with their matched carcinomas from the same patients, and 37 colorectal carcinomas, were obtained from the South Western Sydney Colorectal Tumour Bank (Liverpool Hospital, Australia). All tissue samples were collected prospectively with the informed consent of patients who underwent surgery in the South Western Sydney Area Health Service during the period 2000-2002. The lack of a family history of colorectal cancer or other familial cancer syndrome was ascertained by detailed questionnaire. This study was approved by the Institutional Review Board of the Van Andel Research Institute. Frozen sections $(15 \mu \mathrm{m})$ were prepared from stored tumour specimens. The first, middle, and last slides $(5 \mu \mathrm{m})$ were stained as reference slides. Manual microdissection was carried out on the unstained slides under low 


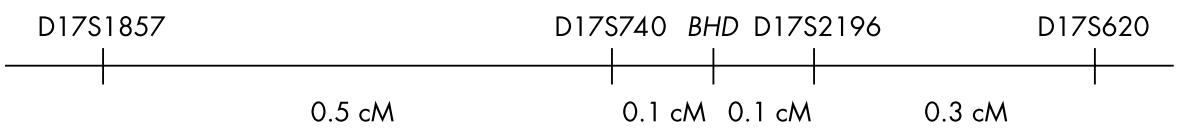

Figure 1 Schematic map of microsatellite markers encompassing the BHD gene. The relative distances (in $c M$ ) between each marker and their relationship to the $B H D$ locus are indicated.

power light microscopy $(20-40 \times)$ by scraping of individual cell populations with a 28 gauge needle. DNA was isolated from microdissected tumour cells and specimens of normal colonic mucosa using the Qiagen DNeasy Mini system (Qiagen, Valencia, CA), according to the manufacturer's instructions. DNA was extracted from peripheral blood leucocytes using the DNA isolation kit for mammalian blood (Roche Molecular Biochemicals).

\section{Analysis of microsatellite instability (MSI) status}

Paired colorectal carcinoma, polyp, and constitutional DNA samples $(n=47)$ were analysed using a panel of 10 microsatellite markers comprising mononucleotide (BAT25, BAT26), dinucleotide (D2S123, D5S346, D18S34, D3S1611), and tetranucleotide (D1S518, D7S1808, D3S2432, D10S1426) repeats. Amplification was performed in a final volume of $10 \mu \mathrm{l}$ containing $25 \mathrm{ng}$ DNA, $20 \mathrm{pmol}$ each primer, $16 \mu \mathrm{mol} / \mathrm{l} \mathrm{dATP}$, $0.2 \mathrm{mmol} / \mathrm{l}$ remaining dNTPs, $0.4 \mu \mathrm{Ci}$ of $\alpha{ }^{33} \mathrm{P}$ [dATP], 50 mmol/l KCl, 10 mmol/l Tris- $\mathrm{HCl}(\mathrm{pH} 8.3), 1.5$ mmol/l $\mathrm{MgCl}_{2}$, and $0.5 \mathrm{U}$ Taq polymerase (Amersham-Pharmacia Biotech). PCR was initiated by a five minute denaturation $\left(94^{\circ} \mathrm{C}\right)$ followed by 34 cycles of denaturation $\left(94^{\circ} \mathrm{C}\right.$, 45 seconds), primer annealing $\left(55-65^{\circ} \mathrm{C}, 45\right.$ seconds $)$, and extension $\left(72^{\circ} \mathrm{C}\right.$, 45 seconds). PCR cycling was ended with a 10 minute extension $\left(72^{\circ} \mathrm{C}\right)$ step. Radioisotope labelled PCR products were electrophoresed on $6 \%$ sequencing gels and visualised by autoradiography. Samples were classified as MSI-L (low level microsatellite instability) if instability was observed at 20-40\% of loci assayed or MSI-H (high level microsatellite instability) if instability was observed at over $40 \%$ of loci assayed. ${ }^{26}$

\section{Mutation analysis}

Mutation screening was performed on all 47 matched samples. The entire coding region of the BHD gene (exons 4-14) was screened. Primer sequences and PCR conditions were according to Nickerson et al. ${ }^{14}$ PCR was performed using a DNA Engine Tetrad (MJ Research, Waltham, MA). PCR products were analysed on standard $1.5 \%$ agarose gels stained with ethidium bromide $(0.5 \mu \mathrm{g} / \mathrm{ml})$ before purification with Multiscreen PCR cleanup plates (Millipore, Molsheim, France). Sequencing reactions were performed using the Big Dye Terminator system (Applied Biosystems, Foster City, CA), purified through Sephadex G-50 (Amersham Biosciences, Uppsala, Sweden) and analysed on an ABI 3700 genetic analyser (Applied Biosystems). We aligned and analysed all sequences by Blast 2 analysis ${ }^{27}$ and manually verified all sequences again. All sequence changes were verified by reamplification of the corresponding $B H D$ fragment and sequencing of both DNA strands.

\section{Analysis of loss of heterozygosity (LOH) status}

$\mathrm{LOH}$ was performed on 36 matched normal/tumour tissue pairs, as well as 10 matched normal/polyp pairs. Allelic deletions of the chromosome $17 \mathrm{p}$ region flanking the $B H D$ gene were assessed using microsatellite markers D17S1857, D17S740, D17S2196, and D17S620. The relative distances between each marker and their relationship to the BHD gene were calculated using the UCSC Genomic Bioinformatics site (fig 1). PCR conditions were according to Khoo et al. ${ }^{13}$ One $\mu \mathrm{l}$ of each PCR product was added to a cocktail containing $5 \mu \mathrm{l}$ of DNAse free, RNAse free distilled water, $10 \mu \mathrm{l}$ of Hi-Di formamide and $0.2 \mu \mathrm{l}$ of ROX 400HD size standard. The mixture was denatured at $95^{\circ} \mathrm{C}$ for five minutes before loading into an $\mathrm{ABI}$ Prism 3700 Genetic Analyzer (Applied Biosystems). Analysis of raw data and assessment of LOH were carried out using
Genescan v 3.7 and Genotyper v 3.7 software (Applied Biosystems). $\mathrm{LOH}$ was defined according to the following formula: $\mathrm{LOH}$ index $=(\mathrm{T} 2 / \mathrm{Tl}) /(\mathrm{N} 2 / \mathrm{Nl})$, where $\mathrm{T}$ was the tumour sample, $\mathrm{N}$ was the matched normal sample, and 1 and 2 were the intensities of smaller and larger alleles, respectively. ${ }^{28}$ If the ratio was $<0.67$ or $>1.3$, the result was determined to be $\mathrm{LOH}$. Initially, the two closest markers (D17S740 and D17S2196) were analysed for LOH. A designation of LOH was given when at least one of the markers had a ratio that was $<0.67$ or $>1.3$. If the $\mathrm{LOH}$ value was close to these thresholds $(0.67+0.1 ; 1.3$ - 0.1), a further two markers, D17S1857 and D17S620, were examined to confirm the $\mathrm{LOH}$ status.

\section{Analysis of BHD promoter methylation profile}

We examined the promoter methylation status of the $B H D$ gene in 23 matched normal/carcinoma sample sets. DNA methylation status was determined by a methylation specific PCR approach (MSP). ${ }^{29}{ }^{30}$ DNA was treated with sodium bisulphite, which converts all unmethylated cytosines to uracils, leaving methylated cytosines unchanged. Briefly, $2 \mu \mathrm{g}$ of DNA was denatured by incubation in $0.2 \mathrm{~mol} / \mathrm{l} \mathrm{NaOH}\left(37^{\circ} \mathrm{C}, 10\right.$ minutes). Cytosines were then modified in $3 \mathrm{~mol} / \mathrm{l}$ sodium bisulphite (adjusted to pH 5.0; Sigma Chemical Co, St Louis, $\mathrm{MO}$ ) and $10 \mathrm{mmol} / \mathrm{l}$ hydroquinone (Sigma) at $50^{\circ} \mathrm{C}$ for 16 hours. DNA samples were then purified through columns (Microcon YM-100, Millipore, Bedford, MA), treated again in $0.3 \mathrm{~mol} / \mathrm{l} \mathrm{NaOH}$, precipitated with ethanol using glycogen as a carrier, and resuspended in $20 \mu \mathrm{l}$ DNAse free, RNAse free distilled water before storing at $-20^{\circ} \mathrm{C}$. The specific primers for methylated sequences were designed as follows: BHDBISF-OF ( $5^{\prime}$-ATGTGGATAGGAAGTTTTAGGTTGGTTATATTT-3') as the forward primer, and BHD-BISF-OR (5'ACAAAATCACACCCAAAACCCCC-3') as the reverse primer. An aliquot of the bisulphite treated product $(2 \mu \mathrm{l})$ was amplified in a $25 \mu \mathrm{l}$ reaction containing $2 \mathrm{mmol} / \mathrm{l} \mathrm{MgCl}_{2}, 0.24 \mathrm{mmol} / \mathrm{l}$ each dNTP (Invitrogen), 0.02 U Taq DNA polymerase (Invitrogen), and $0.1 \mu \mathrm{mol} / \mathrm{l}$ of each primer. PCR conditions were $95^{\circ} \mathrm{C}$ for five minutes followed by 35 cycles of $94^{\circ} \mathrm{C}$ ( 30 seconds), $60^{\circ} \mathrm{C}$ (30 seconds), and $72^{\circ} \mathrm{C}$ ( 45 seconds). PCR was ended with a seven minute extension $\left(72^{\circ} \mathrm{C}\right)$. A nested PCR was then performed using $1 \mu \mathrm{l}$ of the initial amplification reaction. The primers used were BHD-BISF-IF: 5'-GAAATGGTTTTTTTTAGT ATTTTTAGTTGGTG-3' and BHD-BISF-IR: 5'-CCCAAAACCCCC AAACCCA-3', with conditions similar to those described for the preceding PCR amplification, with the exception that 40 amplification cycles were carried out. The PCR products were purified using Microcon YM-100 columns (Millipore). After amplification, $20 \mu \mathrm{l}$ of the $414 \mathrm{bp}$ PCR product was incubated with $0.3 \mathrm{U}$ of RsaI (New England BioLabs Inc, Beverly, MA) for two hours at $37^{\circ} \mathrm{C}$. $\lambda$ DNA $(0.3 \mu \mathrm{g})$ and distilled water were used respectively as positive and negative controls. Products of restriction digestion $(20 \mu \mathrm{l})$ were electrophoresed on $2 \%$ agarose gels containing ethidium bromide, and visualised under UV illumination. The sizes of the RsaI digestion products were 160 and $254 \mathrm{bp}$.

\section{RESULTS}

\section{Tumour MSI status}

Analysis of MSI status showed that eight of 47 tumours tested showed MSI (table 1). This represents approximately 17\% of the sporadic colorectal tumour cases evaluated in this study. Five carcinomas (CRC-7, CRC-17, CRC-18, CRC-46, and CRC52 ) showed a high frequency of MSI (MSI-H), while two carcinomas (CRC-23 and CRC-42) exhibited a low frequency of 
Table $1 \mathrm{MSI}$ and inactivation profiles of the BHD gene in sporadic colorectal carcinomas and polyps

\begin{tabular}{|c|c|c|c|c|c|}
\hline Sample ID & MSI status & $\begin{array}{l}\text { BHD } \\
\text { mutation }\end{array}$ & $\mathrm{LOH}$ & Methylation & \\
\hline CRC-1 & - & - & + & ND & \\
\hline CRC-2 & - & - & + & ND & \\
\hline CRC-3 & - & - & - & ND & \\
\hline CRC-4 & - & - & ND & ND & \\
\hline CRC-6 & - & - & + & - & \\
\hline CRC-7 & $+(H)$ & - & + & ND & \\
\hline CRC-9 & - & - & + & - & \\
\hline CRC-12 & - & - & + & ND & \\
\hline CRC-13 & - & - & - & - & \\
\hline CRC-14 & - & - & + & ND & C. $691 \mathrm{C}>\mathrm{G}$ \\
\hline CRC-17 & $+(H)$ & - & + & - & [579W] \\
\hline CRC-18 & $+(H)$ & - & - & ND & \\
\hline CRC-19 & - & - & + & ND & \\
\hline CRC-20 & - & - & + & ND & \\
\hline CRC-22 & - & - & + & ND & \\
\hline CRC-23 & $+(L)$ & - & + & ND & \\
\hline $23 P$ & - & - & - & ND & \\
\hline CRC-28 & - & s79W & + & - & \\
\hline CRC-30 & - & - & + & - & \\
\hline CRC-31 & - & - & + & - & \\
\hline CRC-34 & - & - & + & ND & \\
\hline $34 \mathrm{P}$ & - & - & + & ND & \\
\hline
\end{tabular}

$34 \mathrm{P}$

CRC-35

$35 \mathrm{P}$

CRC-37

$37 \mathrm{P}$

CRC-38

CRC-42

$42 \mathrm{P}$

CRC-43

$43 \mathrm{P}$

CRC-44

$44 \mathrm{P}$

CRC-45

CRC-46

CRC-48

CRC-49

CRC-50

$50 \mathrm{P}$

CRC-52

CRC-54

CRC-55

CRC-56

$56 \mathrm{P}$

CRC-59

$59 \mathrm{P}$

CRC-60

-

-
-
-
-
-
+
+

$+($ L)

$-$

$-$

$+(\mathrm{H})$

-

$-$

$+(\mathrm{H})$

$-$

$-$

$-$

-

$-$

$\mathrm{P}=$ polyp, - = absent + + = present; $\mathrm{H}=$ high level $M S I ; L=$ low level MSI; ND = not determined.

MSI (MSI-L). CRC-42 also showed a low level of MSI in its corresponding polyp (42P). All other tumours (39 of 47) were microsatellite stable (MSS).

\section{BHD mutations}

Screening of the BHD coding region identified two novel somatic mutations in exon 4 (c.69lC $>G$ ) and exon 12 (c.1788G $>$ A) of CRC-28 and CRC-54, respectively (table 1, fig 2). Both are missense mutations (S79W and A445T), leading to non-conservative amino acid changes. In both cases the carcinomas were MSS and tumours with BHD mutations represented approximately $7 \%$ of the MSS colorectal carcinomas tested $(n=30)$. No mutations were detected in the $(C)_{8}$ repeat tract (nt 1733-1740), known to be a mutational hot spot within the BHD gene, in either the MSI or MSS tumours. BHD mutations were absent in all colon polyps.

\section{LOH status}

$\mathrm{LOH}$ at the chromosomal region surrounding the BHD locus was identified in $81 \%$ (29 of 36$)$ of the sporadic colorectal carcinomas, and $40 \%$ (four of 10) of colon polyps (table 1). The
A
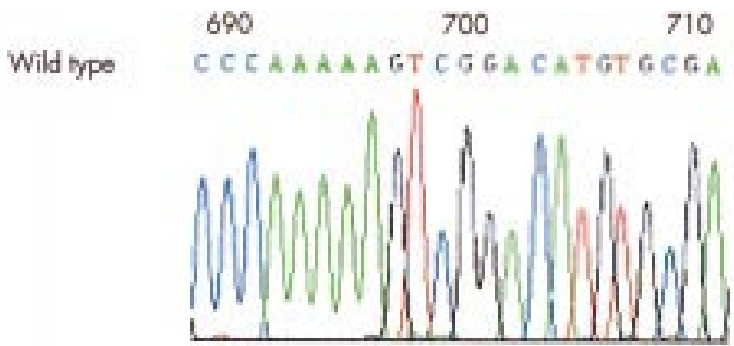

720

730

740

CC CAAAAAGTHGGA CATGTGCGA

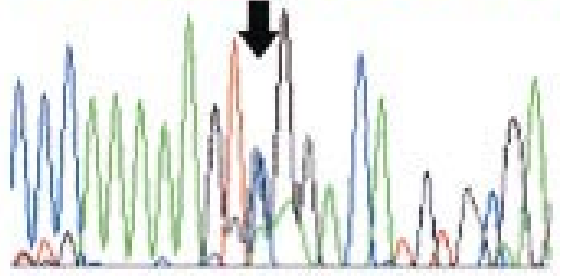

Wild type

CCACGCAGCSGCACOTTCCACCS

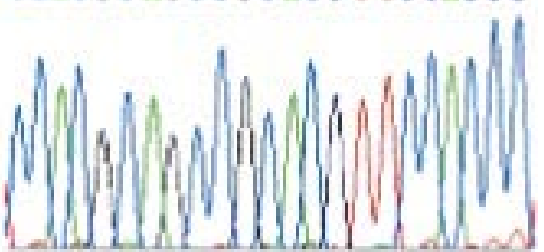

c. $1789 G>A$

90

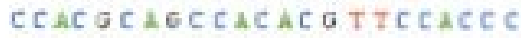

(A445T)

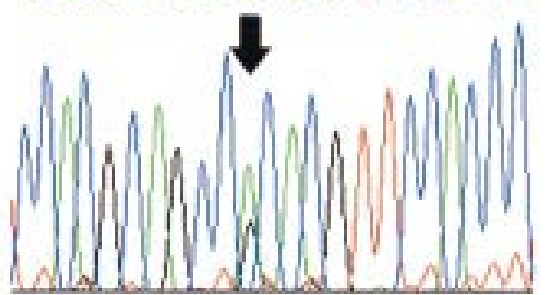

Figure 2 Detection of mutations within the $B H D$ gene in sporadic colorectal cancer. Two novel somatic mutations of the BHD gene were detected in two MSS colorectal carcinomas. Each of the mutations is not present in the matched normal tissues. (A) c.691C>G (S79W) in CRC-28 and (B) c. 1788G>A (A445T) in CRC-54.

four colon polyps with $\mathrm{LOH}$ were from the same people who showed LOH in their colorectal carcinomas (CRC-34, 34P; CRC-42, 42P; CRC-56, 56P; and CRC-59, 59P). CRC-28 showed $\mathrm{LOH}$, along with somatic mutation S79W.

\section{BHD promoter methylation}

Methylation specific PCR analysis of the BHD promoter did not detect any promoter methylation profile differences in the 23 matched sets tested (table 1). Unfortunately, methylation profiles for the rest of the samples could not be determined owing to insufficient DNA being available.

\section{DISCUSSION}

Early studies have reported several cases of colorectal neoplasia in patients with BHD. ${ }^{19-22}$ However, one recent study ${ }^{23}$ showed a lack of statistical significance when comparing the incidence of colon cancer in 111 BHD affected and 112 BHD unaffected subjects, as well as the occurrence of colon polyps 
in 45 BHD affected and 38 BHD unaffected subjects, thus excluding any association between colonic neoplasia and BHD. Nevertheless, we recently reported six cases of colonic polyps and two cases of possible colon cancer in a BHD family with confirmed $B H D$ germline mutations, ${ }^{13}$ indicating that the $B H D$ gene is involved in the tumorigenesis of these BHD related colorectal tumours. In this study, we show that the $B H D$ gene is also involved in a subset of sporadic colorectal cancers. Two cases of MSS colorectal cancer were found to harbour two novel somatic missense mutations, S79W and A445T, in exons 4 and 12, respectively. Interestingly, no frameshift mutation was identified in the hypermutable poly $\mathrm{C}$ tract, particularly in the MSI carcinomas, as this region is a potential site for insertion or deletion in cancers with defective mismatch repair. These results suggest that the $B H D$ gene may be involved in a pathway of colorectal tumorigenesis that is distinct from the pathway of mismatch repair deficiency. However, the sample size of the MSI tumours is small in this series and further investigation is warranted.

The missense mutations detected were non-conservative amino acid substitutions ( $\mathrm{S} 79 \mathrm{~W}$ and $\mathrm{A} 445 \mathrm{~T}$ ) in the BHD gene product which could cause conformational changes in the structure of the protein, leading to dysfunction. ${ }^{31-35}$ Protein phosphorylation, a modulator of protein function and stability, can occur at Ser, Thr, or Tyr residues and is mediated by specific protein kinases. In CRC-28, the change from Ser to Trp leads to the loss of a potential site of phosphorylation whereas the Ala to Thr change in CRC-54 leads to the gain of a potential phosphorylation site. These amino acid changes could lead to altered protein phosphorylation status with consequent functional changes.

LOH, which indicates the loss of one functional copy of a gene, has been used as a marker for diagnosis and prognosis of cancer. In this study, we identified LOH at microsatellite loci flanking the BHD gene in $40 \%$ of colon polyps and $81 \%$ of colorectal carcinomas. Together with the finding of LOH in matched normal/carcinoma samples of LOH negative polyps, we propose that $\mathrm{LOH}$ surrounding the $B H D$ locus may be involved in colorectal cancer progression, although other tumour suppressor genes located on chromosome $17 \mathrm{p}$, such as $p 53$, should not be excluded. The $p 53$ gene is located approximately $9 \mathrm{cM}$ telomeric to the $B H D$ gene. Studies have shown that $\mathrm{LOH}$ at $17 \mathrm{p}$ may be essential for the malignant transformation of benign lesions in colorectal neoplasms. ${ }^{36}{ }^{37}$ Therefore, the effects of $\mathrm{LOH}$ on BHD gene expression and regulation in colorectal tumours merits further investigation.

Sample CRC-28 was found to harbour a mutation in the $B H D$ gene as well as $\mathrm{LOH}$ around the $B H D$ region, which could represent two hits of the $B H D$ gene in accordance with Knudson's classical two hit theory. Apparent biallelic alteration of the BHD gene appears to be uncommon and the high frequency of $\mathrm{LOH}$ in the rest of the tumours without mutations suggests several possibilities. First, loss of a single allele may be the preferred mode of inactivation of the $B H D$ gene and that haploinsufficiency contributes to tumorigenesis. Second, there may be mutations present in the regulatory region of the $B H D$ gene which were not tested in this study. Finally, there may be loss of other tumour suppressor genes in the vicinity of the $B H D$ gene.

DNA methylation is an epigenetic alteration that interferes with transcriptional initiation. In general, methylation of $\mathrm{CpG}$ dinucleotides in the promoter regions of tumour suppressor genes leads to loss of tumour suppressor gene expression (silencing) and consequent function. Hypermethylation of tumour suppressor genes has been frequently reported in many tumour types. We recently identified the involvement of the $B H D$ gene in sporadic renal tumours by showing frequent methylation of the $B H D$ promoter in a wide spectrum of sporadic renal tumours. ${ }^{38}$ In the present study, we did not detect any $B H D$ promoter methylation profile differences in the 23 colorectal carcinoma cases where a sufficient amount of DNA was available for the MSP assay. We conclude that epigenetic alteration of the $B H D$ gene is not a common event in colorectal cancer.

In summary, we have shown that the $B H D$ gene is mutated in a subset of MSS sporadic colorectal carcinomas, and allelic loss around the region of the gene may play a role in the progression of colorectal tumours.

\section{ACKNOWLEDGEMENTS}

The first two authors contributed equally to this work. This study was supported by the Van Andel Foundation.

\section{Authors' affiliations}

K Kahnoski, S K Khoo, J Chen, B T Teh, Laboratory of Cancer Genetics, Van Andel Research Institute, Grand Rapids, Ml-49503, USA N T Nassif, G P Lobo, E Segelov, Cancer Research Laboratories, South West Sydney Clinical School, University of New South Wales, Liverpool Hospital, Liverpool, NSW 2170 , Australia

Correspondence to: Dr N T Nassif, Department of Medicine, University of New South Wales, Level 4, Health Services Building, Cnr Goulburn \& Campbell Streets, Liverpool, NSW 2170, Australia;

n.nassif@unsw.edu.au or Dr B T Teh, Laboratory of Cancer Genetics, Van Andel Research Institute, Grand Rapids, MI-49301, USA; bin.teh@vai.org

\section{REFERENCES}

1 Jemal A, Thomas A, Murray T, Thun M. Cancer Statistics, 2002. Ca Cancer J Clin 2002;52:23-47

2 Bos JL, Fearon ER, Hamilton SR, Verlaan-de Vries M, van Boom JH, van $\operatorname{der} \mathrm{Eb} \mathrm{AJ}$, Vogelstein B. Prevalence of ras gene mutations in human colorectal cancers. Nature 1987;327:293-7

3 Baker SJ, Fearon ER, Nigro JM, Hamilton SR, Preisinger AC, Jessup JM, van Tuinen $P$, Ledbetter DH, Barker DF, Nakamura Y, White R, Vogelstein B. Chromosome 17 deletions and p53 gene mutations in colorectal carcinomas. Science 1989;244:217-21

4 Fearon ER, Cho KR, Nigro JM, Kern SE, Simons JW, Ruppert JM, Hamilton SR, Preisinger AC, Thomas G, Kinzler KW, Vogelstein B. Identification of a chromosome $18 \mathrm{q}$ gene that is altered in colorectal cancers. Science 1990;247:49-56.

5 Kinzler KW, Nilbert MC, Vogelstein B, Bryan TM, Levy DB, Smith KJ, Preisinger AC, Hamilton SR, Hedge P, Markham A, Carlson M, Joslyn G, Groden J, White R, Miki Y, Miyoshi Y, Nishisho I, Nakamura Y. Science 1991;251:1366-70.

6 Lengaver C, Kinzler KW, Vogelstein B. Genetic instabilities in human cancers. Nature 1998;396:643-9.

7 Martin L, Assem M, Piard F. Are there several types of colorectal carcinomas? Correlations with genetic data. Eur J Cancer Prev 1999:8:S13-20.

8 Thibodeau SN, Bren G, Schaid D. Microsatellite instability in cancer of the proximal colon. Science 1993;260:816-19.

9 Ionov Y, Peinado MA, Malkhosyan S, Shibata D, Perucho M. Ubiquitous somatic mutations in simple repeated sequences reveal a new mechanism for colonic carcinogenesis. Nature 1993;363:558-61.

10 Birt AR, Hogg GR, Dubé WJ. Hereditary multiple fibrofolliculomas with trichodiscomas and acrochordons. Arch Dermatol 1977;113:1674-7.

11 Schulz T, Hartschuh W. Birt-Hogg-Dubé syndrome and Hornstein-Knickenberg-syndrome are the same. Different sectioning techniques as the cause of different histology. J Cutan Pathol 1999:26:55-61.

12 Khoo SK, Bradley M, Wong FK, Hedblad MA, Nordenskjöld M, Teh BT. Birt-Hogg-Dubé syndrome: mapping of a novel hereditary neoplasia gene to chromosome 17p12-q11.2. Oncogene 2001;20:5239-42.

13 Khoo SK, Giraud S, Kahnoski K, Chen J, Motorna O, Nickolov R, Binet $O$, Lambert D, Friedel J, Lévy R, Ferlicot S, Wolkenstein P, Hammel P, Bergerheim U, Hedblad MA, Bradley M, Teh BT, Nordenskjöld M, Richard S. Clinical and genetic studies of Birt-Hogg-Dubé syndrome. J Med Genet 2002;39:906-12.

14 Schmidt LS, Warren MB, Nickerson ML, Weirich G, Matrosova V, Toro JR, Turner ML, Duray P, Merino M, Hewitt S, Pavlovich CP, Glenn G, Greenberg CR, Linehan WM, Zbar B. Birt-Hogg-Dubé syndrome, a genodermatosis associated with spontaneous pneumothorax and kidney neoplasia, maps to chromosome 17p1 1.2. Am J Hum Genet 2001;69:876-82

15 Nickerson ML, Warren MB, Toro JR, Matrosova V, Glenn G, Turner ML, Duray P, Merino M, Choyke P, Pavlovich CP, Sharma N, Walther M, Munroe D, Hill R, Maher E, Greenberg C, Lerman MI, Linehan WM, Zbar B, Schmidt LS. Mutations in a novel gene lead to kidney tumors, lung wall defects, and benign tumors of the hair follicle in patients with the Birt-Hogg-Dubé syndrome. Cancer Cell 2002;2:157-64.

16 Roth JS, Rabinowitz AD, Benson M, Grossman ME. Bilateral renal cell carcinoma in the Birt-Hogg-Dubé syndrome. J Am Acad Dermatol 1993;29: 1055-6.

17 Toro J, Glenn G, Duray P, Darling T, Weirich G, Zbar B, Linehan M, Turner M. Birt-Hogg-Dubé syndrome: a novel marker of kidney neoplasia. Arch Dermatol 1999;135: 1195-202. 
18 Chung JY, Ramos-Caro FA, Beers B, Ford MJ, Flowers F. Multiple lipomas, angiolipomas and parathyroid adenomas in a patient with Birt-Hogg-Dubé syndrome. Int J Dermatol 1996;35:365-7

19 Hornstein OP. Generalized dermal perifollicular fibromas with polyps of the colon. Hum Genet 1976:33:193-7.

20 Binet O, Robin J, Vicart M, Ventura G, Beltzer-Garelly E. Fibromes périfolliculaires, polypose colique familiale, pneumothorax spontanés familiaux. Ann Dermatol Venereol 1986;1 13:928-30.

21 Rongioletti F, Hazini R, Gianotti G, Rebora A. Fibrofolliculomas, tricodiscomas and acrochordons (Birt-Hogg-Dubé) associated with intestinal polyposis. Clin Exp Dermatol 1989;14:72-4

22 Sasai S, Takahashi K, Tagami H. Coexistence of multiple perifollicular fibromas and colonic polyp and cancer. Dermatology 1996;192:262-3

23 Zbar B, Alvord WG, Glenn G, Turner M, Pavlovich CP, Schmidt L, Walther M, Choyke P, Weirich G, Hewitt SM, Duray P, Gabril F, Greenberg C, Merino M, Toro J, Linehan WM. Risk of renal and colonic neoplasms and spontaneous pneumothorax in the Birt-Hogg-Dubé syndrome. Cancer Epidemiol Biomarkers Prev 2002;11:393-400.

24 Markowitz S, Wang J, Myeroff L, Parsons R, Sun L, Lutterbaugh J, Fan RS, Zborowska E, Kinzler KW, Vogelstein B, Brattain M, Willson JKV. Inactivation of the type II TGF-beta receptor in colon cancer cells with microsatellite instability. Science 1995;268:1336-8

25 Rampino N, Yamamoto H, lonov Y, Li Y, Sawai H, Reed JC, Perucho M. Somatic frameshift mutations in the BAX gene in colon cancers of the microsatellite mutator phenotype. Science 1997;275:967-9.

26 Boland CR, Thibodeau SN, Hamilton SR, Sidransky D, Eshleman JR, Burt RW, Meltzer SJ, Rodriguez-Bigas MA, Fodde R, Ranzani GN, Srivastava SA. National Cancer Institute Workshop on Microsatellite Instability for cancer detection and familial predisposition: development of international criteria for the determination of microsatellite instability in colorectal cancer. Cancer Res 1998:58:5248-57.

27 Tatusova TA, Madden TL. Blast 2 sequences - a new tool for comparing protein and nucleotide sequences. FEMS Microbial Lett 1999; 174:247-50.

28 Giraud S, Choplin H, Teh BT, Lespinasse J, Lenoir G, Hamon P, Calender A. A large MEN1 family with clinical expression suggestive of anticipation. J Clin Endocrinol Metab 1997;82:3487-92.
29 Herman JG, Graff JR, Myohanen S, Nelkin BD, Baylin SB. Methylation-specific PCR: a novel PCR assay for methylation status of CpG islands. Proc Natl Acad Sci USA 1996;93:9821-6.

30 Esteller $\mathbf{M}$, Herman JG. Cancer as an epigenetic disease: DNA methylation and chromatin alterations in human tumours. J Pathol 2002;196:1-7.

31 Brennan SO, Maghzal G, Shneider BL, Gordon R, Magid MS, George PM. Novel fibrinogen gamma 375 Arg Trp mutation (fibrinogen aguadilla) causes hepatic endoplasmic reticulum storage and hypofibrinogemia. Hepatology 2002;36:652-8

32 Topalian SL, Gonzales MI, Ward Y, Wang X, Wang RF. Revelation of a cryptic major histocompatibility complex class II-restricted tumor epitope in a novel RNA-processing enzyme. Cancer Res 2002;62:5505-9.

33 Tsukaguchi H, Sudhakar A, Le TC, Nguyen T, Yao J, Schwimmer JA, Schachter AD, Poch E, Abreu PF, Appel GB, Pereira AB, Kalluri R, Pollak MR. NPHS2 mutations in late-onset focal segmental glomerulosclerosis: $\mathrm{R} 229 \mathrm{Q}$ is a common disease-associated allele. J Clin Invest 2002; 110:1659-66.

34 Asada-Senju M, Maeda T, Sakata T, Hayashi A, Suzuki T. Molecular analysis of the transferring gene in a patient with hereditary hypotransferrinemia. J Hum Genet 2002;47:355-9.

35 Dhitavat J, Marfarlane S, Dode L, Leslie N, Sakuntabhai A, MacSween $R$, Saihan E, Hovnanian A. Acrokeratosis verruciformis of Hopf is caused by mutation in ATP2A2: evidence that it is allelic to Darier's disease. J Invest Dermatol 2003;120:229-32.

36 Boland CR, Sato J, Appelman HD, Bresalier RS, Feinberg AP. Microallelotyping defines the sequences and tempo of allelic losses at tumor suppressor gene loci during colorectal cancer progression. Nat Med 1995; 1:902-9.

37 Yashiro $M$, Carethers JM, Laghi L, Saito K, Slezak P, Jaramillo E, Rubio C, Koizumi K, Hirakawa K, Boland CR. Genetic pathways in the evolution of morphologically distinct colorectal neoplasms. Cancer Res 2001;61:2676-83.

38 Khoo SK, Kahnoski K, Sugimura J, Petillo D, Chen J, Shockley K, Ludlow J, Knapp R, Giraud S, Richard S, Nordenskiöld M, Teh BT. Inactivation of $B H D$ in sporadic renal tumors. Cancer Res (in press).

\title{
A gene locus for branchio-otic syndrome maps to chromosome 14q21.3-q24.3
}

\author{
R G Ruf, J Berkman, M T F Wolf, P Nurnberg, M Gattas, E-M Ruf, V Hyland, \\ J Kromberg, I Glass, J Macmillan, E Otto, G Nurnberg, B Lucke, H C Hennies, \\ F Hildebrandt
}

B anchio-oto-renal syndrome (BOR, OMIM 113650) is an autosomal dominant disorder characterised by the association of hearing loss (HL), structural ear anomalies, branchial arch defects, and renal anomalies. ${ }^{1}$ The prevalence approximates 1:40 000 in the general population, and has been reported in about $2 \%$ of deaf children. ${ }^{2}$ Age of onset for deafness varies from childhood to early adulthood. ${ }^{3}$ The clinical expression of BOR exhibits wide intra- and interfamilial variability. In addition, reduced penetrance for BOR has been assumed. ${ }^{4}$ The major feature of BOR, which occurs in $93 \%$ of patients, is HL, which can be conductive, sensorineural, or mixed. Besides the classical ear, kidney, and branchial arch anomalies, different developmental manifestations of BOR in other organ systems have been described. Among these, dysfunction of the lacrimal duct system is a common association. ${ }^{5-10}$ Thus, BOR represents a clinically and genetically heterogeneous disease complex that manifests predominantly during organogenesis. A gene locus for autosomal dominant BOR had been localised on chromosome 8q13. ${ }^{112}$ Subsequently, mutations in the human homologue of the Drosophila eyes absent gene (EYAl) have been shown to be causative for BOR (OMIM 601653). ${ }^{13}$ Branchio-otic syndrome (BOS) (OMIM 602588) was initially described as a disorder distinct from BOR, featuring the same clinical symptoms as BOR with

\section{Key points}

- Branchio-oto-renal syndrome (BOR) is an autosoma dominant developmental disorder characterised by the association of hearing loss, branchial arch defects, and renal anomalies. Branchio-otic syndrome (BOS) represents a related disorder presenting with the same clinical features without renal anomalies.

- Recessive mutations in the human homologue of the Drosophila eyes absent gene (EYA 1) have been shown to cause BOR and BOS. A locus (BOS2) for autosomal dominant BOS has been localised to chromosome lq31.

- We performed a genome wide search for linkage in a large pedigree with BOS with more than 40 affected subjects and mapped a new gene locus (BOS3) to chromosome 14q21.3-q24.3. The highest multipoint lod score was $Z \max =4.81$ ( $\theta=$ ) for marker D14S980.

- Identification of the gene causing branchio-otic syndrome type 3 will offer new insights into the development and molecular mechanisms of hearing. 
Table 1 Clinical data of affected subjects from the BOS kindred

\begin{tabular}{|c|c|c|c|c|c|c|c|c|}
\hline \multirow[b]{3}{*}{ Subject } & \multirow[b]{3}{*}{$\mathrm{AO}$} & \multicolumn{4}{|l|}{$\mathrm{HL}$} & \multirow[b]{3}{*}{ EP } & \multirow[b]{3}{*}{$B C$} & \multirow[b]{3}{*}{ LD } \\
\hline & & \multicolumn{2}{|l|}{ SND } & \multicolumn{2}{|l|}{$C D$} & & & \\
\hline & & $\mathrm{R}$ & L & $\mathrm{R}$ & L & & & \\
\hline II.2 & ND & ND & ND & ND & ND & - & - & - \\
\hline 11.3 & ND & ND & ND & ND & ND & + & - & - \\
\hline III.3 & ND & ND & ND & ND & ND & - & - & - \\
\hline III.5 & ND & ND & ND & ND & ND & - & - & - \\
\hline III.9 & $\sim 18$ & $\mathrm{H}+$ to $+++^{*}$ & $\mathrm{H}+$ to $++++++^{*}$ & - & - & - & - & + \\
\hline III. 10 & $\sim 10$ & $\mathrm{H}+$ to $++++^{*}$ & $\mathrm{H}+$ to $++++{ }^{*}$ & - & - & + & - & + \\
\hline III. 12 & $\sim 18$ & ND & ND & ND & ND & - & - & - \\
\hline III. 14 & $\sim 6$ & ND & ND & ND & ND & + & - & - \\
\hline IV. 2 & $\sim 20$ & $\mathrm{H}+$ to $++^{*}$ & $\mathrm{H}+$ to $+++^{*}$ & - & - & - & - & - \\
\hline IV.5 & ND & ND & ND & ND & ND & - & - & - \\
\hline IV. 8 & ND & ND & ND & ND & ND & + & - & - \\
\hline IV.9 & $\sim 3$ & $\mathrm{H}+$ to $+++^{*}$ & $\mathrm{H}+$ to $+++^{*}$ & - & - & - & - & + \\
\hline IV. 12 & $\sim 1$ & A +++++ & A +++ & - & - & - & - & - \\
\hline IV. 13 & $\sim 10$ & +++ & +++ & - & - & - & - & - \\
\hline IV. 14 & ND & + & +++++ & - & - & - & - & - \\
\hline IV.16 & $\sim 20$ & $\mathrm{H}+$ to $++++^{*}$ & $\mathrm{H}+$ to $++++^{*}$ & ND & ND & - & - & - \\
\hline IV. 17 & $\sim 22$ & ++++ & ++++ & - & t+++ & - & - & - \\
\hline IV. 18 & $\sim 13$ & $\mathrm{H}+$ to $+++++^{*}$ & $\mathrm{H}+$ to $+++++{ }^{*}$ & - & - & - & - & - \\
\hline IV. 19 & ND & ND & ND & ND & ND & - & - & - \\
\hline IV. 20 & $\sim 10$ & ND & ND & ND & ND & - & - & - \\
\hline IV.21 & ND & ND & ND & ND & ND & - & - & - \\
\hline V.2 & $\sim 7$ & $\mathrm{H}+$ to ++ & $L+$ & - & - & - & - & - \\
\hline V. 3 & ND & ND & ND & ND & ND & + & - & - \\
\hline V.4 & ND & ND & ND & ND & ND & - & - & - \\
\hline V.5 & ND & ND & ND & ND & ND & - & + & - \\
\hline V.6 & -3 & $\mathrm{H}+$ & $\mathrm{H}+$ & - & - & - & - & - \\
\hline V.7 & ND & $\mathrm{H}++$ & $\mathrm{H}++$ & $\mathrm{L}+$ & $L+$ & - & - & - \\
\hline V. 8 & ND & + & + & - & - & - & + & - \\
\hline V. 10 & ND & ND & ND & ND & ND & - & - & - \\
\hline VI. 1 & 1 & $\mathrm{H}+$ to +++ & $\mathrm{H}+$ to +++ & + & + & - & - & - \\
\hline VI. 2 & $<1$ & $A++++^{\star}$ & A +++++ & - & - & + & + & - \\
\hline VI.3 & 3 weeks & $\mathrm{H}+$ to +++ & $\mathrm{H}+$ to +++ & - & - & - & - & - \\
\hline VI. 4 & 7 & $\mathrm{H}+$ & - & - & - & - & - & - \\
\hline
\end{tabular}

the exception of renal anomalies. ${ }^{1}$ The large variety of clinical phenotypes and the description of mutations in the EYAl gene for BOR and BOS patients ${ }^{13-15}$ show that BOR and BOS can represent allelic defects of the EYAl gene. The identification of a second gene locus in a large BOS pedigree on chromosome lq31 established the presence of genetic locus heterogeneity for BOS. ${ }^{4}$ No linkage to this locus has been published for BOR families and the gene defect is still to be identified. The issue of genotype/phenotype relationships regarding clinical features of BOR or BOS remains unsolved. We describe here a genome wide search for linkage in a large pedigree with BOS, in which linkage to the EYAl locus on chromosome 8q13 had been excluded, resulting in a new locus (BOS3) on chromosome 14q.

\section{METHODS}

Blood samples and clinical data for a large multigeneration family with over 40 affected subjects with BOS were obtained after informed consent was given by patients and unaffected relatives. The ethnic origin of the family was Anglo-Saxon Australian. Clinical examinations and renal ultrasound were performed in 32 affected family members. Twenty blood samples were collected ( 14 from affected subjects, six from unaffected relatives or partners) and DNA was extracted for molecular analysis. All 32 affected subjects had deafness $(100 \%)$. In 17 affected family members, precise audiometric data were available. Diagnosis was sensorineural HL in 14 of them $(82 \%)$ and mixed HL in three of them $(18 \%)$. The affected frequencies varied from low to high frequencies as well as the presence of HL in all frequencies. Severity varied from mild to severe HL being still progressive in six cases. Among subjects IV.14, IV.17, and V.2 differences in the HL between the right and left ear were found. In IV.14 sensorineural HL was mild in the right ear whereas it was moderate to severe in the left ear. In IV.17, in addition to moderate to severe sensorineural HL on both sides, moderate to severe conductive HL was present only on the left side. In V.2 high frequency HL in the right ear differed from low frequency in the left ear. Age of onset was very variable with an average of 9.5 years, ranging from 3 weeks to 22 years. Eight subjects $(25 \%)$ had branchial arch defects, three with branchial cysts, and six with ear pits as external ear manifestation (table 1 ).

Figure 1 Haplotypes on chromosome 14q12-q23 of the BO family. Haplotypes are shown for the subjects where DNA was available (indicated by an arrow) or haplotypes could be inferred. Thirteen microsatellite markers are shown on the left from cen to qter (top to bottom). Filled upper right quadrant indicates diagnosis of hearing loss, filled lower right quadrant ear pits, filled upper left quadrant lacrimal duct stenosis, and filled lower left quadrant branchial cysts. Haplotypes are interpreted as differently coloured bars. Paternal haplotypes are drawn to the left, maternal ones to the right. Segments of haplotypes which could not unambiguously be assigned to the paternal or maternal haplotype are represented by a thin line. Inferred haplotypes are indicated in parentheses. The black haplotype cosegregates with the affected status. Note that marker D14S1013 is flanking the BOS3 locus on its centromeric borders, as defined through a recombination in II.2, and that marker D14S53 is flanking the BOS3 locus at its q terminal border as defined by a recombination in V.5. Flanking markers are underlined. 


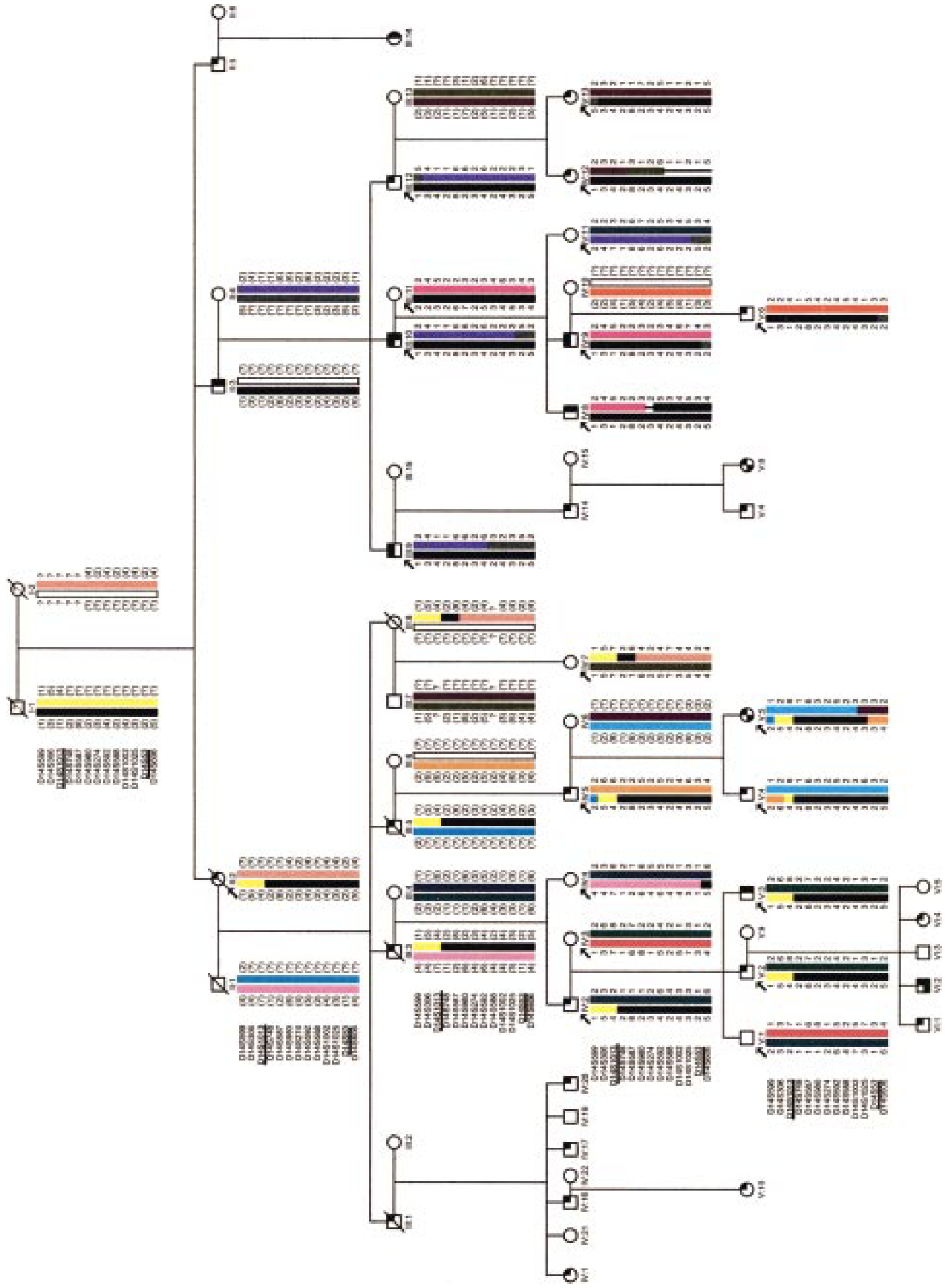




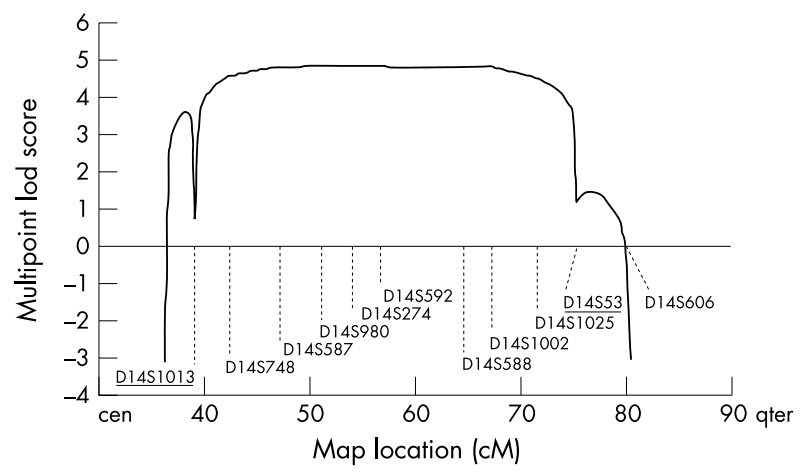

Figure 2 Multipoint lod scores for the BOS3 locus on chromosome $14 q 21.3-q 24.3$ versus the 13 markers shown in fig 1. Relative position is given in $\mathrm{cM}$ according to the Genethon map. ${ }^{18}$ The two markers D14S1013 and D14S53 flanking the BOS3 region (fig 1) are underlined. cen, centromeric orientation; qter, q terminal orientation.

In three affected subjects (9\%) lacrimal duct stenosis was diagnosed as a common feature associated with BOR/BOS. No congenital renal anomalies were found, although two adult affected sibs had renal carcinomas, which most likely was coincidental. The absence of congenital renal anomalies suggests a diagnosis of BOS rather than BOR in this family. Genomic DNA was isolated, by standard methods, ${ }^{16}$ either directly from blood samples or after Epstein-Barr-virus transformation of peripheral blood lymphocytes. ${ }^{17}$ DNA was available for haplotype analysis in 14 affected and six unaffected subjects for the genome wide search for linkage. In the other subjects haplotypes were inferred if possible (fig 1). A total of 380 microsatellite markers from the Genethon final linkage map ${ }^{18}$ with an average spacing of $11 \mathrm{cM}$ were used. For further fine mapping on chromosome 14q21.3-q24.3, six additional markers, with an average distance of $3.5 \mathrm{cM}$, were used. Order and sex averaged distances (in parentheses) between these markers from centromeric to q telomeric are as follows: D14S599 (2.9 cM), D14S306 (2.8 cM), D14S1013 (3.2 cM), D14S748 (4.5 cM), D14S587 (4.1 cM), D14S980 (2.9 cM), Dl4S274 (3.9 cM), Dl4S592 (8.0 cM), D14S588 (2.9 cM), D14S1002 (4.5 cM), D14S1025 (3.7 cM), D14S53 (5.1 cM), and D14S606. ${ }^{18}$ Semiautomated genotyping was performed with a MegaBACE-1000 analysis system. Data were analysed by Genetic Profiler Software, version 1.1. Two point lod score calculations were performed by the LINKAGE program package, ${ }^{19}$ with the help of the LINKRUN computer program ( $\mathrm{T}$ F Wienker, unpublished data), using an autosomal dominant model with $100 \%$ penetrance and a gene frequency for BOS of 0.0001 . The "lodmax - 1 support interval" was defined as the genetic map positions intersecting the lod score curve at $\mathrm{Zmax}=1 .{ }^{20}$ For haplotyping and computation of multipoint lod scores, the program SIMWALK ${ }^{21}$ was used, assuming equal allele frequencies. Because of the reduced penetrance described in BOR/BOS, the calculations were performed on basis of an "affecteds only" strategy.

\section{RESULTS}

Before starting the genome wide search for linkage, the EYAl gene locus was excluded by linkage and mutational analysis. By evaluating the results of the genome wide search, the locus for BOS on chromosome lq31 was also excluded for this kindred (data not shown). From the total genome search for linkage, only for one locus was cosegregation of the haplotype pattern in all affected subjects found for markers D14S587, D14S592, and D14S588 on chromosome 14q21.3-q24.3, yielding a maximum two point lod score of $\mathrm{Zmax}=3.27(\theta=0)$ for marker D14S587 (table 1). Further fine mapping with an additional six markers confirmed the locus. Haplotype analysis showed clear evidence that the disease allele cosegregated with all affected subjects and was absent from unaffected subjects (fig 1). A recombination event in II.2 defined marker D14S1013 as proximally flanking, and a recombination in V.5 identified marker DI4S53 as distally flanking the critical genetic region within a $37.7 \mathrm{cM}$ interval on chromosome 14q21.3-q24.3. Multipoint analysis of the 11 markers resulted in a $\mathrm{Zmax}=4.81$ at marker DI4S980 at relative position 50.9 (fig 2). The $95 \%$ confidence interval at $\mathrm{Zmax}=\mathrm{I}^{20}$ extends over a 33.9 cM interval between the markers DioS1013 and Dl0S53 within the set of 11 microsatellites. Marker D14S980 also showed the highest two point lod score value $\mathrm{Zmax}=4.1 \mathrm{l}$ $(\theta=0)$ (table 2$)$.

\section{DISCUSSION}

Here we have reported a third gene locus for BOS, BOS3, which maps to chromosome 14q21.3-q24.3. According to the UCSC Genome Browser, the interval between markers D14S1013 and D14S53 spans a physical distance of approximately 33 $\mathrm{Mb}$, relative marker positions are 41383995 and 74328 130, respectively. A recombination in the healthy subject III.8 could define marker Dl4S587 as proximally flanking. As reduced penetrance for BOS is known, this does not represent a secure border. Further fine mapping with more affected members of this pedigree and examination of other familial cases with BOS will help to refine this region. In contrast to the pedigree

\begin{tabular}{|c|c|c|c|c|c|c|c|c|c|}
\hline \multirow[b]{2}{*}{ Marker } & \multicolumn{8}{|c|}{ Two point lod scores at recombination fraction $\theta=$} & \multirow[b]{2}{*}{$Z \max (\theta)$} \\
\hline & 0 & 0.001 & 0.01 & 0.05 & 0.1 & 0.2 & 0.3 & 0.4 & \\
\hline D14S599 & -4.991 & -3.645 & -1.891 & -0.659 & -0.237 & 0.02 & 0.053 & 0.028 & $0.053(0.3)$ \\
\hline D14S306 & -4.220 & -2.777 & -0.984 & 0.192 & 0.529 & 0.585 & 0.381 & 0.127 & $0.585(0.2)$ \\
\hline D14S1013 & -0.135 & 0.624 & 1.494 & 1.926 & 1.892 & 1.492 & 0.953 & 0.419 & $1.926(0.05)$ \\
\hline D14S748 & 1.902 & 1.898 & 1.853 & 1.656 & 1.410 & 0.934 & 0.508 & 0.182 & $1.902(0.0)$ \\
\hline D14S587 & 3.268 & 3.261 & 3.202 & 2.933 & 2.590 & 1.881 & 1.170 & 0.518 & $3.268(0.0)$ \\
\hline D14S980 & 4.114 & 4.107 & 4.038 & 3.726 & 3.321 & 2.461 & 1.544 & 0.638 & $4.114(0.0)$ \\
\hline D14S274 & 2.163 & 2.157 & 2.097 & 1.830 & 1.492 & 0.831 & 0.286 & 0.005 & $2.163(0.0)$ \\
\hline D14S592 & 2.672 & 2.666 & 2.612 & 2.371 & 2.067 & 1.459 & 0.876 & 0.368 & $2.672(0.0)$ \\
\hline D14S588 & 1.962 & 1.958 & 1.922 & 1.756 & 1.544 & 1.108 & 0.679 & 0.298 & $1.962(0.0)$ \\
\hline D14S1002 & 3.359 & 3.353 & 3.295 & 3.033 & 2.696 & 1.995 & 1.275 & 0.583 & $3.359(0.0)$ \\
\hline D14S1025 & 2.254 & 2.249 & 2.201 & 1.988 & 1.717 & 1.166 & 0.634 & 0.214 & $2.254(0.0)$ \\
\hline D14S53 & 0.324 & 1.064 & 1.925 & 2.335 & 2.272 & 1.816 & 1.208 & 0.568 & $2.335(0.05)$ \\
\hline D14S606 & -4.205 & -2.769 & -0.981 & 0.188 & 0.517 & 0.568 & 0.388 & 0.173 & $0.568(0.2)$ \\
\hline
\end{tabular}


described by Kumar et al linked to chromosome 1q31, where HL was diagnosed in $50 \%$ of the affected subjects, deafness seems to be a major feature in this pedigree. As $25 \%$ of the patients show an association with branchial arch defects, a non-syndromic form of deafness is unlikely. The diagnosis of lacrimal duct stenosis, a common association of BOR and $\mathrm{BOS}$, further confirms the diagnosis of BOS. The HL varied in form, severity, frequency, and the age of onset among the different family members and even between the ears of one patient, a characteristic feature of BOR and BOS. The low percentage of branchial arch defects compared to previously described families with BOS and BOR can be explained either by the known variable expressivity or by the genetic heterogeneity of BOS.

Genes encoding proteins involved in renal and otic morphogenesis and organogenesis are good candidates. EYAl deficient mice have been shown to lack ears and kidneys and show abnormal apoptosis of organ primordia. ${ }^{22}$ Another member of the EYA gene family, EYA4, is responsible for late onset deafness. ${ }^{23}$ EYA2 and EYA3 are excluded from the BOS 3 locus on chromosome 14, as they are localised on chromosomes 20 and 1, respectively. Gene loci for non-syndromic forms of autosomal dominant ${ }^{24}$ and autosomal recessive deafness ${ }^{25}$ were mapped to the critical interval on chromosome 14q21.3-q24.3. Whether the autosomal dominant form is an allelic variant of BOS requires the identification of the causative gene. Identification of the gene causing BOS3 in this pedigree and other patients with BOS will lead to new insights into the pathophysiology and development of auditory function.

\section{ACKNOWLEDGEMENTS}

We thank all the patients, their family members, and their physicians for their participation in this study. FH was supported by a grant from the German Research Foundation (SFB 592).

Data access. URL for data in this article are as follows: Genethon map: http://www.cephb.fr/ceph-genethon-map.html. Online Mendelian Inheritance in Man (OMIM): http://www.ncbi.nlm.nih.gov/Omim UCSC Genome Browser: http://genome.ucsc.edu/.

\section{Authors' affiliations}

R G Ruf, M T F Wolf, E Otto, F Hildebrandt, Departments of Pediatrics and Human Genetics, University of Michigan, Ann Arbor, USA

J Berkman, M Gattas, J Kromberg, J Macmillan, Queensland Clinical Genetics Service, Royal Children's Hospital, Brisbane, Queensland, Australia

P Nurnberg, G Nurnberg, Gene Mapping Centre and Department of Molecular Genetics, Max-Delbrueck Centre for Molecular Medicine, Berlin-Buch, Germany

P Nurnberg, Institute of Medical Genetics, Charité University Hospital, Humboldt University, Berlin, Germany

E-M Ruf, University Children's Hospital, Freiburg, Germany

V Hyland, Molecular Genetics Laboratory, Queensland Health Pathology Service, Queensland, Australia

I Glass, Departments of Pediatrics and Medicine, University of Washington School of Medicine, Seattle, USA

Correspondence to: Dr F Hildebrandt, University of Michigan Health System, 8220C MSRB III, 1150 West Medical Center Drive, Ann Arbor, Ml 48109,USA; fhilde@umich.edu

\section{REFERENCES}

1 Melnick M, Bixler D, Nance WE, Silk K, Yune H. Familial branchio-oto-renal dysplasia: a new addition to the branchial arch syndromes. Clin Genet 1976;9:25-34
2 Fraser FC, Sproule JR, Halal F. Frequency of the branchio-oto-renal (BOR) syndrome in children with profound hearing loss. Am J Med Genet 1980;7:341-9.

3 Hone SW, Smith RJ. Genetics of hearing impairment. Semin Neonatol $2001 ; 6: 531-41$

4 Kumar S, Deffenbacher K, Marres HA, Cremers CW, Kimberling WJ. Genome wide search and genetic localization of a second gene associated with autosomal dominant branchio-oto-renal syndrome: clinical and genetic implications. Am J Hum Genet 2000;66:1715-20.

5 Fitch N, Srolovitz H. Severe renal dysplasia produced by a dominant gene. Am J Dis Child 1976;130:1356-7.

6 Cremers CW, Fikkers-van Noord M. The earpits-deafness syndrome: clinical and genetic aspects. Int J Pediatr Otorhinolaryngol 1980;2:309-22

7 Preisch JW, Bixler D, Ellis FD. Gustatory lacrimation in association with the branchio-oto-renal syndrome. Clin Genet 1985;27:506-9.

8 Heimler A, Lieber E. Branchio-oto-renal syndrome: reduced penetrance and variable expressivity in four generations of a large kindred. Am J Med Genet 1986;25:15-27

9 Pennie BH, Marres HA. Shoulder abnormalities in association with branchio-oto-renal dysplasia in a patient who also has familial joint laxity. Int J Pediatr Otorhinolaryngol 1992;23:269-73.

10 Weber KM, Kousseff BG. New manifestations of BOR syndrome. Clin Genet 1999;56:306-12

11 Haan EA, Hull YJ, White S, Cockington R, Charlton P, Callen DF. Tricho-rhino-phalangeal and branchio-oto syndromes in a family with an inherited rearrangement of chromosome 8q. Am J Med Genet 1989; 32:490-4

12 Ni L, Wagner M, Kimberling WJ, Pembrey ME, Grundfast KM, Kumar S, Daiger SP, Wells DE, Johnson K, Smith RJH. Refined localization of the branchiootorenal syndrome gene by linkage and haplotype analysis. Am J Med Genet 1994;51:176-84.

13 Abdelhak S, Kalatzis V, Heilig R, Compain S, Samson D, Vincent C, Weil D, Cruaud C, Sahly I, Leibovici M, Bitner-Glindzicz M, Francis $M$, Lacombe D, Vigneron J, Charachon R, Boven K, Bedbeder P, Van Regemorter N, Weissenbach J, Petit C. A human homologue of the Drosophila eyes absent gene underlies branchio-oto-renal (BOR) syndrome and identifies a novel gene family. Nat Genet 1997:15:157-64.

14 Vincent C, Kalatzis V, Abdelhak S, Chaib H, Compain S, Helia J, Vaneecloo FM, Petit C. BOR and BO syndromes are allelic defects of EYA1. Eur J Hum Genet 1997:5:242-6.

15 Fukuda S, Kuroda T, Chida E, Shimizu R, Usami S, Koda E, Abe S, Namba A, Kitamura K, Inuyama Y. A family affected by branchio-oto syndrome with EYA1 mutations. Auris Nasus Larynx 2001;28:7-1 1.

16 Maniatis T, Fritsch EF, Sambrook J. Molecular cloning. A laboratory manual. 2nd ed. Cold Spring Harbour, NY: Cold Spring Harbour Laboratory Press, 1987.

17 Steel CM, Philipson J, Arthur E, Gardiner SE, Newton MS, McIntosh RV Possibility of $E B$ virus preferentially transforming a subpopulation of human B lymphocytes. Nature 1979;270:729-30.

18 Dib C, Faure S, Fizames C, Samson D, Drouot N, Vignal A, Millasseau $\mathrm{P}$, et al. A comprehensive genetic map of the human genome based on 5,264 microsatellites. Nature 1996;380:152-4.

19 Lathrop GM, Lalouel JM. Easy calculations of lod scores and genetic risks on small computers. Am J Hum Genet 1984;36:460-5.

20 Conneally PM, Edwards JH, Kidd KK, Lalouel JM, Morton NE, Ott J, White R. Report of the Committee on Methods of Linkage Analysis and Reporting. Cytogenet Cell Genet 1985;40:356-9.

21 Sobel E, Lange K. Descent graphs in pedigree analysis: Applications to haplotyping location scores, and marker sharing statistics. Am J Hum Genet 1996;58:1323-37.

22 Xu PX, Adams J, Peters H, Brown MC, Heaney S, Maas R. Eya l-deficient mice lack ears and kidneys and show abnormal apoptosis of organ primordial. Nat Genet 1999;23:1 13-17.

23 Wayne S, Robertson NG, DeClau F, Chen N, Verhoeven K, Prasad S, Tranebjarg L, Morton CC, Ryan AF, Van Camp G, Smith RJ. Mutations in the transcriptional activator EYA4 cause late-onset deafness at the DFNA10 locus. Hum Mol Genet 2001:10:195-200.

24 Salam AA, Hafner FM, Linder TE, Spillmann T, Schinzel AA, Leal SM. A novel locus (DFNA23) for prelingual autosomal dominant nonsyndromic $\mathrm{HL}$ maps to $14 \mathrm{q} 21-\mathrm{q} 22$ in a Swiss German kindred. Am J Hum Genet 2000;66:1984-8

25 Ansar M, Din MA, Arshad M, Sohail M, Faiyaz-Ul-Haque M, Haque S, Ahmad W, Leal SM. A novel autosomal recessive non-syndromic deafness locus (DFNB35) maps to 14q24.1-14q24.3 in large consanguineous kindred from Pakistan. Eur J Hum Genet 2003;11:77-80. 


\title{
Mitotic recombination mediated by the JJAZF 1 (KIAAO 160) gene causing somatic mosaicism and a new type of constitutional NF1 microdeletion in two children of a mosaic female with only few manifestations
}

\author{
E Petek, D E Jenne, J Smolle, B Binder, W Lasinger, C Windpassinger, K Wagner, \\ P M Kroisel, H Kehrer-Sawatzki
}

J Med Genet 2003;0:520-525

$\mathrm{N}$ eurofibromatosis type 1 (NF1) is an autosomal dominant disorder with an estimated birth incidence of 1 in 2500 and marked variability of expression. The hallmark symptoms of the fully manifested disease encountered in nearly all patients are cutaneous neurofibromas, café au lait spots, axillary freckling, and Lisch nodules. Other common manifestations are bone dysplasias, scoliosis, vasculopathy, and learning disabilities. NFl patients also suffer from an increased risk of specific tumour types like plexiform neurofibromas, neurofibrosarcomas, optic gliomas, other CNS tumours, phaeochromocytomas, juvenile xanthogranuloma, and juvenile myeloid leukaemia. Mutations of the NFI gene at $17 q 11.2$ encoding neurofibromin are the molecular basis of the disease. Neurofibromin contains a GTPase activating domain and is a negative regulator of Ras GTPases. Homozygous inactivation of neurofibromin is associated with a dysregulation of Ras mediated signalling pathways and tumorigenesis in NFl patients. ${ }^{1}$ More than $70 \%$ of the germline mutations are protein truncating and are distributed throughout the coding region. ${ }^{2-4}$ No distinct genotypephenotype correlation concerning type and position of the mutations has been established, apart from patients with microdeletions of the NF1 gene region, which are associated with a more severe clinical phenotype and facial dysmorphism. This was recognised very early and confirmed by several studies. ${ }^{5-9}$ Molecular characterisation of the deletion boundaries showed that non-allelic recombination between two highly homologous sequences separated by $\sim 1.5 \mathrm{Mb}$ eliminates 14 genes together with the NF1 gene during germ cell development. ${ }^{10-14}$ These $60-85 \mathrm{~kb}$ spanning low copy repeats are derived from segments of the WI-12393 gene and contain sequences with homology to chromosome 19. The structure of the NF1 gene region at $17 \mathrm{q} 11.2$ is further complicated by other duplicated sequences, such as pseudogene exons of the SMURF2 and the KIAA0160 genes. ${ }^{10}{ }^{15}$ Up to now, homologous recombination between these duplicated sequences during mitotic cell divisions has not been reported. Here, we describe two brothers with severe NF1. Their mother, who does not fulfil the diagnostic criteria for NF1, only has a few inconspicuous café au lait spots and lacks any neurofibromas and other tumours. She shows somatic mosaicism for a large deletion of the NFI gene region in peripheral blood leucocytes and skin fibroblasts. We determined the mechanism underlying the deletion and the size of the deleted interval at the cytogenetic and molecular level with respect to the duplicated sequences in the NFI region.

\section{MATERIAL AND METHODS}

\section{Patients}

The 60 year old female investigated in this study (II.2, fig 1) has four café au lait spots on her thighs and forearms. Some minor freckling was found in the left axilla, but she did not have dermal neurofibromas or Lisch nodules. Her two sons, however, suffer from a severe form of NFl (patients III.l and III.2). In early childhood, they had multiple café au lait spots distributed all over the body and noticeably large hands and feet. In the younger brother, retarded psychomotor development was documented. Later in life, coarse facial features with hypertelorism were noticed, in addition to macrocephaly, axillary freckling, mild scoliosis, and multiple neurofibromas, which were too numerous to count. Multiple melanocytic naevi and low set nipples were additional features. The intelligence quotient of the sons was judged by their mother as normal, but was specifically tested only in her oldest son and was found to be in the normal range. Both attended regular school. Patient III.l suffered from a malignant glandular schwannoma in the left gluteus which metastasised. At the age of 29 years, he died from intracranial bleeding before genetic investigations were started. His younger brother, patient III.2, who

\section{Key points}

- Large deletions of the NF1 gene region at $17 q 11.2$ have been observed in $5-20 \%$ of all NFI patients and are most frequently about $1.5 \mathrm{Mb}$ in size. In the majority of these NFI patients, a segment of a similar size carrying 14 functional genes is eliminated during meiosis by homologous recombination between low copy repeats (LCRs) of the WI-12393 gene and sequences with homology to chromosome 19.

- Here we report on two brothers suffering from a severe form of NFl and their mother, who does not fulfil the general diagnostic criteria for NF1. Marker and FISH analyses showed mosaicism for a large microdeletion of the NFl gene region in the mother. The microdeletion was transmitted to her younger son and probably to her older son as well, who died from complications of the disease some years ago.

- By contrast to previously characterised microdeletions, we located the breaks in another duplicated segment of the NFI region, the KIAA0160 gene and its pseudogene. The disrupted KIA0160 gene is closely flanked by the WI-12393 gene, which is retained, and by WI-12393 related LCR sequences on the distal and proximal side, which have been shown to be involved in homologous recombination in other patients with NFI microdeletions.

- We conclude that somatic recombination between the KIAA0160 gene, which has also been called JJAZFI, and its pseudogene caused gonadosomatic mosaicism of the large deletion in the mother. Furthermore, marker analysis showed that mitotic intrachromosomal recombination is the mechanism underlying this deletion. 


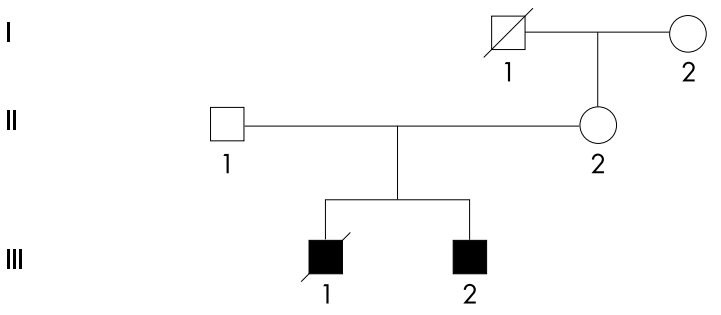

\begin{tabular}{|c|c|c|c|c|c|c|c|c|}
\hline & & & $\begin{array}{c}\text { Hybric } \\
8,17\end{array}$ & $\begin{array}{c}\text { Hybrid } \\
4,15\end{array}$ & & & & \\
\hline D17S1873 & 140 & 120 & 120 & 152 & 136 & 152 & 144 & 152 \\
\hline D17S1841 & 275 & 267 & 267 & 267 & 265 & 267 & 275 & 267 \\
\hline D17S975 & 255 & 255 & 255 & 263 & 259 & 263 & 259 & 263 \\
\hline D17S1863 & 259 & 257 & 257 & 259 & 259 & 259 & 253 & 259 \\
\hline D17S635 & 94 & 102 & 102 & - & 98 & (98) & 98 & 98 \\
\hline D17S1849 & 211 & 235 & 235 & - & 211 & (211) & 237 & 211 \\
\hline D17S1166 & 203 & 195 & 195 & - & 195 & (195) & 203 & 195 \\
\hline D17S 1800 & 268 & 276 & 276 & - & 276 & (276) & 268 & 276 \\
\hline D17S1880 & 194 & 178 & 178 & 196 & 186 & 196 & 196 & 196 \\
\hline D17S907 & 289 & 334 & 334 & 314 & 330 & 314 & 318 & 314 \\
\hline D17S1833 & 160 & 158 & 158 & 158 & 146 & 158 & 156 & 158 \\
\hline D17S1788 & 155 & 155 & 155 & 155 & 159 & 155 & 153 & 155 \\
\hline D17S1867 & 97 & 93 & 93 & 95 & 95 & 95 & 95 & 95 \\
\hline
\end{tabular}

Figure 1 Genotype analysis of 11 polymorphic markers flanking the NFl gene region and two markers within the NFl gene (D17S1849, D17S1 166) in the family of the index patient III.2. The haplotypes of patient III. 2 were determined by analysing two hybrids, Nos 4 and 15, carrying only the deleted chromosome 17 and two hybrids, Nos 8 and 17, with the normal chromosome 17 Patient III. 2 is hemizygous for markers D17S635, D17S1849, DI7S1 166, and D17S1800. Markers in parentheses located within the deleted interval of proband II.2 are present as single copies in the majority of peripheral blood leucocytes.

is still alive, had sphenoid wing dysplasia. At the age of 11 years, progressive dislocation of his hips and genu valgum were diagnosed, which had to be surgically corrected several times.

\section{FISH analysis}

Chromosome spreads were prepared from peripheral blood lymphocytes and skin fibroblasts of proband II.2 and blood lymphocytes of her son (the index patient III.2) according to standard methods. Skin fibroblasts of the mother were obtained by a punch biopsy of the left axillary region. BAC clones used as FISH probes were purchased from the BAC/PAC Resource Center (www.chori.org/bacpac) and have previously been characterised..$^{111} 15$ PCR products used as FISH probes, DJ1686/1863, DJHK10/11, and DJ1576/1578, were amplified with primers listed in table 1 using the Expand Long Template PCR System (Roche Molecular Biochemicals). The respective products were cloned with the TOPO TA Cloning System (Invitrogen) and labelled for FISH analysis. Two colour FISH was performed using BAC-DNA or the cloned PCR products labelled either with biotin-16-dUTP or digoxygenin-11-dUTP (Roche-Diagnostics, Mannheim, Germany). Hybridisation signals were visualised by FITC-avidin and biotinylated anti-avidin (Vector, Burlingame, USA) or with antidigoxygenin antibodies and in a second step with anti-mouse antibodies conjugated to Texas-Red (Dianova, Hamburg, Germany). Slides were counterstained with diamidinophenylindole (DAPI) and mounted with Vectashield antifade solution (Vector, Burlingame, USA).

\section{Genotyping and generation of hybrid cell lines}

Markers analysed were D17S1873, Dl7S1841, D17S975, D17S1863, and D17S635 proximal to the NF1 gene and markers D17S1800, D17S1880, D17S907, D17S1833, D17S1788, and D17S1867 distal to the NF1 gene. Markers D17S1849 and D17S1 166 within the NFI gene were also investigated. Genotyping was performed with 6FAM labelled primers and capillary electrophoresis on an ABI PRISM 3100 Genetic Analyzer (Applied Biosystems). For PCR experiments, we used DNA isolated from blood lymphocytes and hybrid cell lines carrying the deleted chromosome of patient III.2 (hybrid line Nos 4 and 15) and from hybrids with the normal chromosome 17 of III.2 (Nos 8 and 17) to identify the haplotypes. The hybrid cell lines were generated by PEG mediated fusion of a mouse cell line with peripheral blood lymphocytes of patient III.2 (GMP Genetics, Suffolk, UK). Hybrid cell lines were genotyped with the standard set of markers routinely used by GMP Genetics. Marker analysis in all other members of the family was performed using genomic DNA from peripheral blood.

\section{Analysis of markers within the genomic interval between the KIAA0160 gene and its pseudogene}

Dinucleotide repeat marker IVS27AC28.4 in intron 27b of the NF1 gene was amplified with Cy5 labelled PCR primers as described by Lazaro et $a l^{16}$ and analysed on an ALF-Express Sequencer (Amersham Pharmacia). The single nucleotide polymorphism SNP2 located in the KIAA1821 gene was amplified with primers described by Eisenbarth et al. ${ }^{17}$ Resulting PCR products were digested with the restriction enzyme MboI and analysed by agarose gel electrophoresis.

\section{Fine mapping of the deletion breakpoints}

The region of the deleted interval and the adjacent segments were analysed by PCR using polymorphic and nonpolymorphic STS markers and DNA from a hybrid cell line carrying only the deleted chromosome 17 of patient III.2. PCR products flanking the deletion boundaries, DJ1911/1910, DJ1561/1562, and DJ1948/1936, were amplified with primers DJ1911 (5' CTGCACATGGCATTGTTTGATT 3') and DJ1910 (5' AAACCCTCCTTGTGCCCTACTC 3'), DJ1561 (5' GTCCAATAAG CAAGAAAAGAGCAA 3') and DJI562 (5' TGGGGAAGAAAACATCAGTCAA 3'), DJ1948 (5' GAGAAAATGAAAGGAGAGCAAGAA 3') and DJ1936 (5' TCTTAGTGCCTCTGGGAGCAA $\left.3^{\prime}\right)$. PCR products were directly sequenced by cycle sequencing on an ABI 377 sequencer (Applied Biosystems) and analysed using the GCG software (Genetics Computer Group) to determine their origin and to evaluate whether sequences are derived from one or two distinct loci.

\begin{tabular}{|c|c|c|c|c|}
\hline Primer & Sequence $\left(5^{\prime} \rightarrow 3^{\prime}\right)$ & $\begin{array}{l}\text { Amplified from } \\
\text { BAC (Acc No) }\end{array}$ & $\begin{array}{l}\text { Position on } \\
\text { BAC }\end{array}$ & $\begin{array}{l}\text { Size of PCR } \\
\text { product (bp) }\end{array}$ \\
\hline $\begin{array}{l}\text { DJ1576 } \\
\text { DJ1578 }\end{array}$ & $\begin{array}{l}\text { GACTGAATTGTATGATTTTGTCC } \\
\text { AATTACTGGG GGCTTCAGGAT }\end{array}$ & $\begin{array}{l}\text { 640N20 } \\
\text { (AC090616) }\end{array}$ & $\begin{array}{l}67241 \\
79694\end{array}$ & 12453 \\
\hline $\begin{array}{l}\text { DJ1686 } \\
\text { DJ1863 }\end{array}$ & $\begin{array}{l}\text { CAGGTTATAGGGAAGGAGGAC } \\
\text { AGCAGCGGTTAAGCAATGATG }\end{array}$ & $\begin{array}{l}\text { 640N20 } \\
(\mathrm{ACO} 090616)\end{array}$ & $\begin{array}{l}98021 \\
104095\end{array}$ & 6074 \\
\hline $\begin{array}{l}\text { DJHK10 } \\
\text { DJHK11 }\end{array}$ & $\begin{array}{l}\text { CATGGGGCTTCTAAACCAGA } \\
\text { GCCTCTGGAGAGGGAGAAGA }\end{array}$ & $\begin{array}{l}307 \mathrm{~A} 16 \\
(\mathrm{AC} 003041)\end{array}$ & $\begin{array}{l}4242 \\
8373\end{array}$ & 4131 \\
\hline
\end{tabular}


A

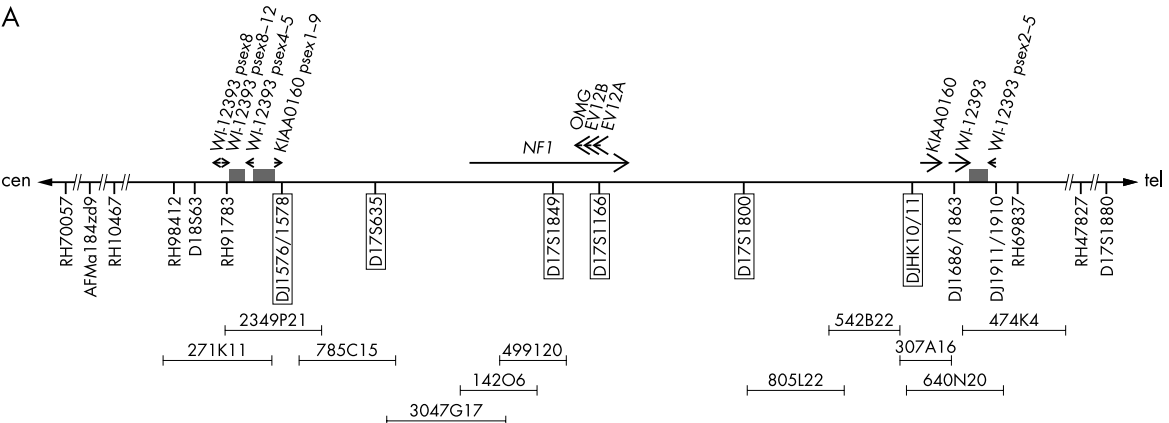

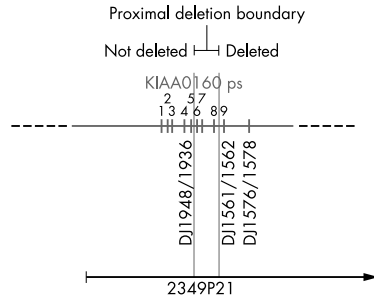

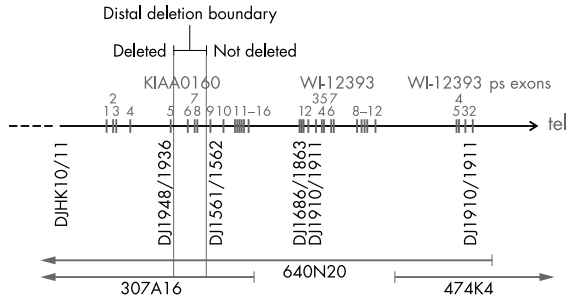

$丁$

Deleted interval

Figure 2 (A) Schematic presentation of the NFl gene region at $17 q 11.2$ and the localisation of STS markers as well as FISH probes. The deletion extent was determined by STS analysis of hybrid cell lines carrying only the deleted chromosome 17 from patient III.2 and by FISH on metaphase chromosomes prepared from the index patient (III.2) and his mother (II.2). The horizontal bar represents chromosome 17. The position of the NFl gene, the functional KIAAO160 gene, the functional WI-12393 gene, and their pseudogene exons (psex) is indicated by arrows. STS markers and FISH probes (DJ1576/1578, DJHK10/11) are indicated by marks below the horizontal line. Deleted markers and probes are highlighted by a frame. BAC clones used for FISH are depicted by horizontal bars. The low copy repeats flanking the NF1 gene region consist of fragments of the Wl-12393 gene and segments with high homology to chromosome 19 sequences, which are indicated by the grey rectangles. (B) Fine mapping of the deletion boundaries within the KIAAOI60 sequences. The exons of the functional KIAAOI60 and WI-12393 genes and their pseudogenes are shown by vertical rectangles with numbers based on the functional genes. The position of segments amplified with primers DJ1948/1936, DJ1561/1562, and DJ1910/1911 as well as the location of the FISH probes DJ1576/1578 and DJ1686/1863 are indicated beneath the horizontal line representing chromosome 17. As determined by FISH, PCR analysis, and sequencing of these products, the proximal deletion breakpoint maps between exons 5 and 9 of the KIAAO160 pseudogene. The distal deletion boundary is located between exons 5 and 9 of the functional KIAAO 160 gene.

\section{RESULTS}

\section{Deletion detection by haplotype analysis and FISH}

Analysis of polymorphic markers showed a large deletion of the NFl gene region in the index patient III.2, as hemizygosity for markers D17S635, D17S1849, D17S1166, D17S1800 was observed in the DNA of peripheral blood lymphocytes (fig 1). To confirm these findings, FISH was performed with BAC $142 \mathrm{O} 6$ (AC079915), which covers the proximal region of the NFl gene. ${ }^{15}$ A deletion of the corresponding region on one chromosome 17 was observed in all blood lymphocytes of patient III.2 $(n=50)$. Upon this finding, the mother (patient II.2) of the index patient was also investigated by FISH. In her blood lymphocytes, the deletion was detected in $70 \%$ of the metaphases analysed $(n=50)$, whereas in fibroblast cultures, the deletion of BAC 14206 was noted only in $15 \%$ of all metaphases $(n=20)$ (data not shown).

\section{Delineation of the deletion boundaries by FISH}

To determine the extent of the deletion, we performed FISH with further BACs that have previously been mapped to the NF1 gene region (figs 2 and 3). ${ }^{10-15}$ On metaphase chromosome spreads of the index patient III.2 and his mother, BACs 785C15, 3047G17, 499I20, 805L22, and 542B22 are deleted on one chromosome 17. Using BACs 2349P21 and 307Al6 as FISH probe ( fig $3 \mathrm{~A}, \mathrm{~B}$ ), a reduced signal was observed on one chromosome 17 homologue suggesting that these BACs span the deletion breakpoints on the affected chromosome. Convincing reduction of signal intensities was not observed using BACs $271 \mathrm{~K} 1 \mathrm{l}$ and $474 \mathrm{~K} 4$ as FISH probes, which span the WI-12393 gene derived LCRs ( fig 2A). To confine the dele- tion boundaries more precisely, FISH was performed with the cloned PCR products DJ1576/1578 amplified from BAC 2349P21 and DJHK10/11 amplified from BAC 307Al6 (fig 2, fig 3C, D). Both probes are deleted on one chromosome 17 homologue. FISH probe DJ1686/1863, spanning exon 1 of the functional WI-12393 gene, hybridised to both chromosomes $17 q 11.2$ and is therefore not deleted. These findings strongly suggest that the proximal deletion breakpoint maps to the region of the KIAA0160 pseudogene and the distal breakpoint to the functional KIAA0160 gene (fig 2B).

\section{Identification of the deletion boundaries by PCR}

PCR analysis of several STS using DNA from hybrid cell lines that carry only one chromosome 17 homologue of the index patient III.2 allowed us to confirm the presence of a large deletion (fig 2A). The markers that are framed in fig 2A were absent in the hybrid lines 4 and 15, but could be amplified from DNA of hybrids 8 and 17. To narrow down the boundaries more precisely, PCR products located within duplicated KIAA0160 and WI-12393 regions were amplified from the hybrid cell lines carrying the deleted chromosome 17 homologue and were sequenced. The location of these three primer pairs, DJ1948/1936, DJ1561/1562, and DJ1910/1911, is indicated in fig 2B. Sequence analysis of amplified products and comparison with the known sequences for 2349P2l (AC127024), 778K9 (AC023266), 307Al6 (AC003041), and 640 N20 (AC090616) enabled us to determine the presence or absence of the functional WI-12393 gene and the distally located WI-12393 pseudogene fragment, as well as the functional KIAA0160 gene and its pseudogene sequences. The 

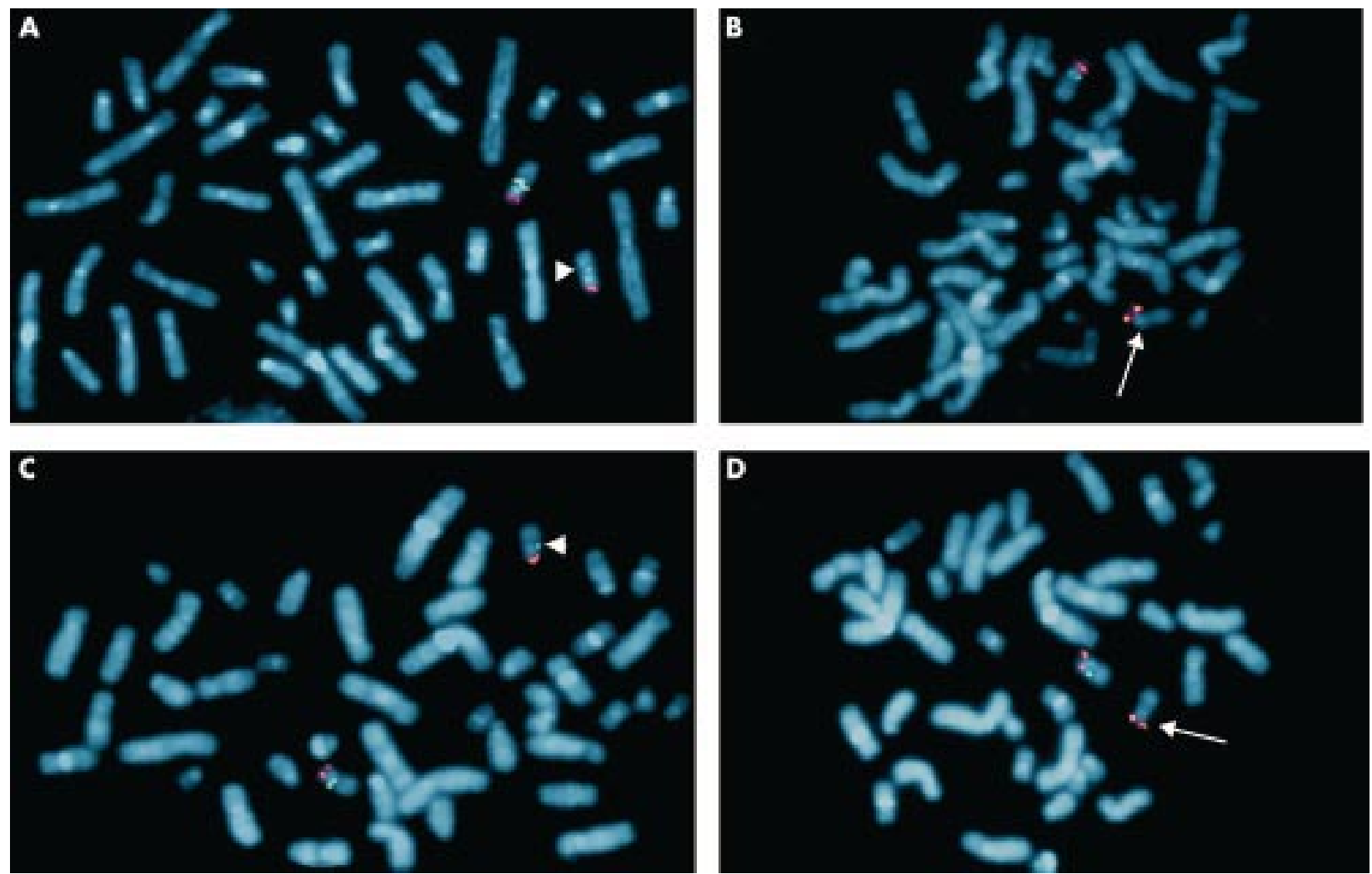

Figure $3 \mathrm{FISH}$ analysis to investigate the deletion boundaries on metaphase chromosomes in the index patient III.2. BAC and PCR probes from the 17q11.2 region labelled with biotin and detected by FITC (green) were cohybridised with BAC 1D5 (red) as reference, which maps to 17p13. The BACs 2349P21 (A) and 307A16 (B) showed a reduced signal on one chromosome 17 (arrowhead) and thus cover the proximal and distal deletion boundaries, respectively. FISH analysis of probe DJ1576/1578 (C) and DJHK10/11 (D) showed the complete absence of the corresponding sequences on one chromosome 17 homologue marked by an arrow.

PCR product DJ1910/1911 amplified from total DNA of the hybrid cell line 4 carrying only the deleted chromosome 17 contained sequences from both the functional WI-12393 gene and its distally located pseudogene. This result clearly indicates that the deletion does not include these regions and that the breakpoint lies centromeric to intron 2 of the WI-12393 gene. The DJ1910/1911 segment occurs only within the LCR sequence on the distal side of the NFI gene and is not present in the proximal LCR. ${ }^{15}$ Examination of the PCR fragment DJ1948/1936, however, showed that this product was exclusively derived from the KIAA0160 pseudogene fragment located on BAC 2349P21. The sequence of the DJ1948/1936 product was unique and did not contain the functional KIAA0160 gene which on the other hand could be coamplified from the hybrids with the normal chromosome 17. By contrast, analyses of the PCR product DJ1561/1562 showed sequences that were solely amplified from the functional KIAA0160 gene, which is located on BAC 640N20 and 307Al6, whereas the PCR product from the normal chromosome was mixed up with sequences from the pseudogene. Therefore, we conclude that the distal and proximal breaks are located within a duplicated segment between exons 5 and 9 of the KIAA0160 gene and its pseudogene, respectively.

\section{Mechanism underlying the deletion}

To determine the recombination mechanism resulting in the deletion, polymorphic markers were also analysed in the grandmother, I.2, of the index patient. Haplotypes were determined in patient III.2 using the hybrid cell lines 4,15 and 8,17 carrying only the deleted or normal chromosome of the index patient III.2. The phases of the haplotypes of the grandmother I.2 were inferred on the most parsimonious assumption that the haplotype of II.2 is not the result of a recombination event between grandmaternal haplotypes within the interval analysed (fig 1). According to our findings, intrachromosomal recombination between highly homologous KIAA0160 sequences was associated with the deletion.

To show that the deletion occurred somatically in proband II.2, we investigated further markers in the genomic interval between the KIAA0160 pseudogene and the functional KIAA0160 gene and observed heterozygosity of proband II.2 in fibroblast cultures for the dinucleotide repeat marker IVS27AC28.4 in intron 27b of the NF1 gene and for the single nucleotide polymorphism SNP2 located in the KIAA1821 gene, flanking the NF1 gene in the 3' direction (fig 4). The heterozygosity of these markers in normal cells of proband II.2 excludes the possibility that the germline deletion occurred during meiosis in the grandmother, and was partially corrected by mitotic recombination or segmental conversion of the deleted chromosome during early embryogenesis in somatic cells of proband II.2.

\section{DISCUSSION}

The NFl gene has one of the highest mutation rates in humans $\left(\sim 1 \times 10^{4} /\right.$ gamete/generation $)$ and about $50 \%$ of all $\mathrm{NFl}$ patients have no family history of the disease. This high mutation rate cannot be simply explained by the enormous size of the NFl gene which spans $350 \mathrm{~kb}$. It has been suggested that the high proportion of sporadic NFl patients mirrors not only new mutations in the germline of a parent but also postzygotic NFl gene mutations associated with gonadosomatic mosaicism in the transmitting unaffected parent (fig 5). ${ }^{18}$ Somatic mosaicism is clearly implicated in the pathogenesis of segmental neurofibromatosis, ${ }^{19}$ but only documented at the cytogenetic level for one patient. ${ }^{20}$ With regard to point mutations, somatic mosaicism of the NFI gene is difficult to 
A

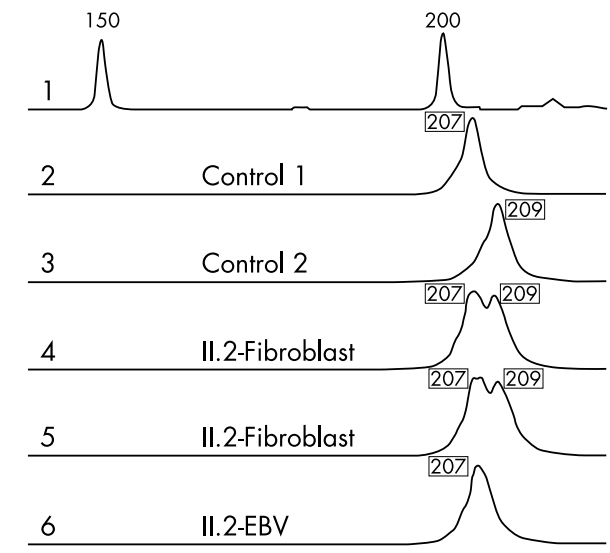

B
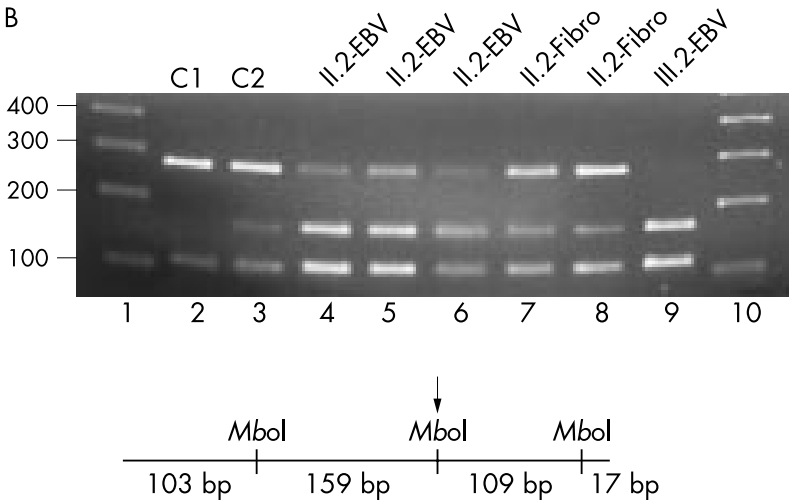

Figure 4 (A) Heterozygosity of the dinucleotide repeat marker IVS27AC28.4 located in intron 27b of the NFI gene was observed in DNA isolated from primary fibroblast cultures. These cultures contained only a minor population of about $15 \%$ cells with del(17)(q1 1.2) (lanes 4 and 5, alleles of 207 and 209 bp). By contrast, the EBV cell line of patient II.2 mainly consists of cells $(85-90 \%)$ carrying the deletion and thus only one allele of $207 \mathrm{bp}$ was detected by this method (lane 6). In lane 1, an external size standard is given. (B) Heterozygosity of the single nucleotide polymorphism SNP2 in patient II.2. SNP2 is located in the KIAA1821 gene, which directly flanks the NFl gene in the 3' direction. The $388 \mathrm{bp}$ spanning PCR product was digested with $\mathrm{Mbol}$ before gel electrophoresis. As indicated in the diagram, the PCR fragment contains two constitutional Mbol sites and one polymorphic Mbol site (arrow). In lanes 1 and 10, standards are loaded with the band sizes given in base pairs on the left. Control DNA from $\mathrm{Cl}$ (lane 2) is homozygous for the allele lacking the Mbol restriction site, the control C2 (lane 3) is heterozygous. In lanes 4 to 6 the Mbol digested PCR fragments from patient II.2 were analysed and the results for different DNA preparations of the EBV cell line are shown. The percentage of cells carrying the deletion varied between $80-90 \%$ in different subcultures. Despite this high percentage of hemizygous cells present in the cultures, heterozygosity is observed at a disproportionate level. Most probably, single stranded DNA molecules without the Mbol restriction site that are not extended during the final PCR cycles form uncleavable heteroduplexes with alleles containing the $\mathrm{Mbol}$ site. These heteroduplexes presumably increase the amount of the uncleaved 268 bp band artificially. In conclusion, the fibroblasts of patient II.2 (lanes 7 and 8) are heterozygous, although they only contain $15 \%$ of cells with the deletion, whereas lymphocytes of the index patient III. 2 are hemizygous for the marker SNP2.

detect and to analyse in tissues, but may be one of the factors contributing to the relatively high number of sporadic cases and to the considerable variability of clinical signs and symptoms in NFl patients.

Interstitial microdeletions, however, can be approached by FISH more easily and thus somatic mosaicism has been detected in a few NFl patients at the cytogenetic level. ${ }^{80-26}$ Large deletions of the NF1 region have been reported in six

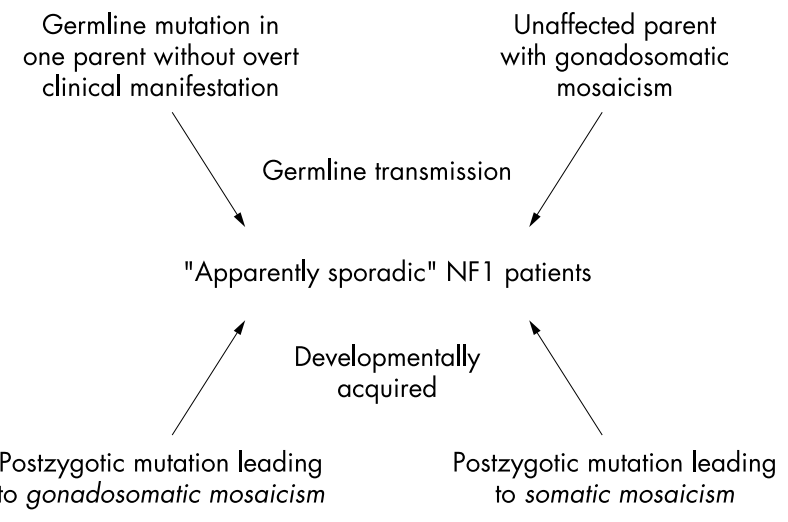

Figure 5 The different origins of sporadic forms of NF1.

patients who all showed generalised NFl symptoms not restricted to a particular body region. Four patients had deletions of the whole NFI gene as shown by FISH analysis ${ }^{23-26}$ and two were ascertained by marker analysis. ${ }^{21} 22$ Moreover, Tinschert $e a^{20}$ described a patient with segmental NFl who is mosaic for an interstitial NF1 deletion. Breakpoint boundaries in all these seven cases have not been analysed so far and thus the underlying mechanism of mitotic rearrangements remains unclear.

Here, we describe a female with minor signs of the disease, who, however, is mosaic for a large deletion of the NF1 gene region. She transmitted this deletion to her son, who developed a severe microdeletion syndrome. The deletion encompasses a segment of $\sim 1.3 \mathrm{Mb}$ and is the result of non-allelic recombination between the KIAA0160 pseudogene on the proximal side and the functional KIAA0160 gene located distally to the NFI gene (fig 2). This is the first published case of an NF1 microdeletion mediated by recombination within the KIAA0160 gene. In 29 of $60 \mathrm{NF} 1$ patients with constitutional microdeletions characterised so far with respect to the deletion boundaries, the breakpoints were identified in highly homologous segments of the WI-12393 gene derived duplicons which flank the NFI gene region. ${ }^{12-14}$ The KIAA0160 gene and its pseudogene are also duplicated segments, which are located in close proximity to the WI-12393 gene derived low copy repeats (fig 2A). The KIAA0160 gene, recently termed JJAZl (Joined to Juxtaposed with Another Zinc Finger gene) has been shown to be disrupted by somatically acquired translocations $t(7 ; 17)(\mathrm{pl} 5 ; \mathrm{q} 21)$ in endometrial stromal sarcomas. This type of translocation not only fuses the promoter and 5' end of the JAZFI gene on chromosome 7 to the coding portion of the KIAA0160 (JJAZI) gene on chromosome $17,{ }^{27}$ but may also reduce the physiological activity of the KIAA0160 product as a result of hemizygosity at the KIAA0160 locus. While it seems premature to construct a link between hemizygosity of the KIAA0160 locus and tumour progression, it might be suspected that the triple event, loss of one $J A Z F 1$ allele, creation of a new fusion transcript between $J A Z F 1$ and KIAA0160, as well as the loss of one KIAA0160 copy triggers the development of endometrial sarcomas as a whole. Similarly, haploinsufficiency of KIAA0160 (JJAZ) may contribute to the outgrowth and progression of neurofibromas in microdeletion patients. Our speculation that KIAA0160 (JJAZF1) serves some tumour suppressive function, which may also be disturbed in endometrial stromal tumours, is consistent with the high risk and early development of tumours observed in patients carrying constitutional microdeletions.

The present study shows that the KIAA0160 gene in conjunction with its pseudogene represents a second recombinational pitfall in the NFI gene region, besides the WI-12393 gene derived duplicons. Genotype analyses clearly indicate that the deletion occurred somatically in proband II.2 by an intrachromosomal (sister chromatid based) mechanism (figs 1 and 3). 
According to previous studies, low copy repeat mediated de novo deletions are believed to be triggered by meiotic recombination during germ cell development. ${ }^{1428}$ This notion was based on PCR experiments that failed to identify the patient specific junction product in the blood of their healthy parents. ${ }^{14}$ López Correa et $\mathrm{l}^{28}$ observed a strong maternal bias for $17 \mathrm{q} 11.2$ microdeletions and found that the $1.5 \mathrm{Mb}$ spanning deletions occurred predominantly during maternal germ cell development. In five of the six informative families, interchromosomal recombination (non-sister chromatid exchange) was the underlying mechanism that caused the rearrangements.

Our study implies that somatic recombination between duplicated sequences at $17 \mathrm{q} 11.2$ during early embryonic development can lead to gonadosomal and tissue mosaicism with only mild signs of NF1, which do not meet the diagnostic criteria. Subsequent germline transmission of such a microdeletion, however, can generate a very severe form of NFl in the offspring with developmental retardation and high tumour load. The risk of somatic mosaicism in patients with very mild or ambiguous signs of NFI who do not fulfil the usual diagnostic criteria is widely ignored or underestimated, but can have dramatic consequences, as in our family.

\section{ACKNOWLEDGEMENTS}

We thank Helene Spöri and Antje Kollak for expert technical assistance. The Institute of Medical Biology and Human Genetics at the University of Graz is a member of the IBMS and was supported by the infrastructure programme UGP4 by the Austria Ministry of Education, Science and Culture. This research was supported by grants of the Oesterreichische Nationalbank (No 9522/EP), by the FÖF (No S7403/PMK), and by the Deutsche Forschungsgemeinschaft (HA1082 and KE-724 2-1/HK-S) and (KFO 113-1/DEJ).

\section{Authors' affiliations}

E Petek, C Windpassinger, K Wagner, P M Kroisel, Institute of Medical Biology and Human Genetics, University of Graz, Austria D E Jenne, W Lasinger, Max-Planck-Institute of Neurobiology, Department of Neuroimmunology, Martinsried, Germany

J Smolle, B Binder, Department of Dermatology, University of Graz, Austria

H Kehrer-Sawatzki, Department of Human Genetics, University of Ulm, Ulm, Germany

Correspondence to: Dr H Kehrer-Sawatzki, Department of Human Genetics, University of Ulm, Albert-Einstein-Allee 11,89081 Ulm, Germany; hildegard.kehrer-sawatzki@medizin.uni-ulm.de

\section{REFERENCES}

1 Huson SM. Neurofibromatosis 1: a clinical and genetic overview. In: Huson SM, Hughes RAC, eds. The neurofibromatoses. pathogenetic and clinical overview. London, Chapman \& Hall 1994, 160-201.

2 Heim RA, Kam-Morgan LN, Binnie CG, Corns DD, Cayouette MC, Farber RA, Aylsworth AS, Silverman LM, Luce MC. Distribution of 13 truncating mutations in the neurofibromatosis 1 gene. Hum Mol Genet 1994:4:975-81.

3 Park VM, Pivnick EK. Neurofibromatosis type 1 (NF1): a protein truncation assay yielding identification of mutations in $73 \%$ of patients. $J$ Med Genet 1998;35:813-20.

4 Fahsold R, Hoffmeyer S, Mischung C, Gille C, Ehlers C, Kucukceylan N, Abdel-Nour M, Gewies A, Peters H, Kaufmann D, Buske A, Tinschert S, Nuernberg P. Minor lesion mutational spectrum of the entire NFl gene does not explain its high mutability but points to a functional domain upstream of the GAP-related domain. Am J Hum Genet 2000;66:790-818

5 Kayes LM, Burke W, Riccardi VM, Bennett R, Ehrlich P, Rubenstein A, Stephens K. Deletions spanning the neurofibromatosis 1 gene: identification and phenotype of five patients. Am J Hum Genet 1994;54:424-36

6 Cnossen $M H$, van der Est MN, Breuning MH, van Asperen CJ, Breslau-Siderius EJ, van der Ploeg AT, de Goede-Bolder A, van den Ouweland AM, Halley DJ, Niermeijer MF. Deletions spanning the neurofibromatosis type 1 gene: implications for genotype-phenotype correlations in neurofibromatosis type 1? Hum Mutat 1997;9:458-64.

7 Valero MC, Pascual-Castroviejo I, Velasco E, Moreno F, Hernandez-Chico C. Identification of de novo deletions at the NFI gene: no preferential paternal origin and phenotypic analysis of patients. Hum Genet 1997;99:720-6.

8 Rasmussen SA, Colman SD, Ho VT, Abernathy CR, Arn PH, Weiss L, Schwartz C, Saul RA, Wallace MR. Constitutional and mosaic large NFI gene deletions in neurofibromatosis type 1. J Med Genet 1998;35:468-71.

9 Upadhyaya M, Ruggieri M, Maynard J, Osborn M, Hartog C, Mudd S, Penttinen M, Cordeiro I, Ponder M, Ponder BA, Krawczak M, Cooper DN. Gross deletions of the neurofibromatosis type 1 (NF1) gene are predominantly of maternal origin and commonly associated with a learning disability, dysmorphic features and developmental delay. Hum Genet 1998;102:591-7.

10 Dorschner MO, Sybert VP, Weaver M, Pletcher BA, Stephens K. NF 1 microdeletion breakpoints are clustered at flanking repetitive sequences. Hum Mol Genet 2000;9:35-46

11 Jenne DE, Tinschert S, Stegmann E, Reimann H, Nürnberg P, Horn D, Naumann I, Buske A, Thiel G. A common set of at least 11 functional genes is lost in the majority of NF1 patients with gross deletions. Genomics 2000;66:93-7.

12 Jenne DE, Tinschert S, Reimann H, Lasinger W, Thiel G, Hameister H, Kehrer-Sawatzki $\mathrm{H}$. Molecular characterization and gene content of breakpoint boundaries in patients with neurofibromatosis type 1 with 17q11.2 microdeletions. Am J Hum Genet 2001;69:516-27.

13 López Correa C, Brems H, Lazaro C, Estivill X, Clementi M, Mason S, Rutkowski JL, Marynen P, Legius E. Molecular studies in 20 submicroscopic neurofibromatosis type 1 gene deletions. Hum Mutat 1999; 14:387-93

14 López Correa C, Dorschner M, Brems H, Lazaro C, Clementi M, Upadhyaya M, Dooijes D, Moog U, Kehrer-Sawatzki H, Rutkowski JL, Fryns JP, Marynen P, Stephens K, Legius E. Recombination hotspot in NF microdeletion patients. Hum Mol Genet 2001;10:1387-92

15 Jenne DE, Tinschert S, Dorschner MO, Hameister H, Stephens K, Kehrer-Sawatzki H. Complete physical map and gene content of the human NF1 tumor suppressor region in man and mouse. Genes Chrom Cancer (in press).

16 Lazaro C, Gaona A, Estivill X. Two CA/GT repeat polymorphisms in intron 27 of the human neurofibromatosis (NF1) gene. Hum Genet 1994;93:351-2

17 Eisenbarth I, Vogel G, Krone W, Vogel W, Assum G. An isochore transition in the NFl gene region coincides with a switch in the extent of linkage disequilibrium. Am J Hum Genet 2000;67:873-80.

18 Zlotogora J. Mutations in von Recklinghausen neurofibromatosis: an hypothesis. Am J Med Genet 1993;46:182-4

19 Ruggieri M, Huson SM. The clinical and diagnostic implications of mosaicism in the neurofibromatoses. Neurology 2001;56:1433-43.

20 Tinschert S, Naumann I, Stegmann E, Buske A, Kaufmann D, Thiel G, Jenne DE. Segmental neurofibromatosis is caused by somatic mutation of the neurofibromatosis type 1 (NF1) gene. Eur J Hum Genet 2001;8:455-9.

21 Ainsworth PJ, Chakraborty PK, Weksberg R. Example of somatic mosaicism in a series of de novo neurofibromatosis type 1 cases due to a maternally derived deletion. Hum Mutat 1997;9:452-7.

22 Colman SD, Rasmussen SA, Ho VT, Abernathy CR, Wallace MR. Somatic mosaicism in a patient with neurofibromatosis type 1. Am J Hum Genet 1996:58:484-90.

23 Tonsgard JH, Yelavarthi KK, Cushner S, Short MP, Lindgren V. Do NF gene deletions result in a characteristic phenotype? Am J Med Genet 1997;73:80-6.

24 Wu BL, Boles RG, Yaari H, Weremowicz S, Schneider GH, Korf BR. Somatic mosaicism for deletion of the entire NFI gene identified by FISH. Hum Genet 1997;99:209-13.

25 Streubel B, Latta E, Kehrer-Sawatzki H, Hoffmann GF, Fonatsch C Rehder H. Somatic mosaicism of a greater than 1.7-Mb deletion of genomic DNA involving the entire NFI gene as verified by FISH: further evidence for a contiguous gene syndrome in 17q11.2. Am J Med Genet 1999;87:12-16.

26 Riva P, Corrado L, Natacci F, Castorina P, Wu BL, Schneider GH, Clementi $M$, Tenconi $R$, Korf BR, Larizza L. NF 1 microdeletion syndrome: refined FISH characterization of sporadic and familial deletions with locus-specific probes. Am J Hum Genet 2000;66:100-9.

27 Koontz JI, Soreng AL, Nucci M, Kuo FC, Pauwels P, van Den Berghe H, Cin PD, Fletcher JA, Sklar J. Frequent fusion of the JAZF1 and JJAZ1 genes in endometrial stromal tumors. Proc Natl Acad Sci USA 2001;98:6348-53.

28 López Correa C, Brems H, Lazaro C, Marynen P, Legius E. Unequal meiotic crossover: a frequent cause of NFI microdeletions. Am J Hum Genet 2000;66:1969-74. 


\title{
Unusual cognitive and behavioural profile in a Williams syndrome patient with atypical 7q1 1.23 deletion
}

\author{
C Gagliardi, M C Bonaglia, A Selicorni, R Borgatti, R Giorda
}

J Med Genet 2003;40:526-530

W illiams syndrome (WS, MIM 194050) is a rare (frequency $1 / 20000$ ) multisystemic disorder ${ }^{1}$ caused by haploinsufficiency of genes at $7 \mathrm{q} 11.23 .^{2-4} \mathrm{WS}$ is associated with dysmorphic facial features, supravalvular aortic stenosis (SVAS) and other cardiovascular diseases, infantile hypercalcaemia, and growth deficiency. The full intelligence quotient (IQ) of WS subjects is usually in the 50s to 60s, with a unique cognitive profile, characterised by relatively good verbal abilities alongside a low level of spatial and constructive organisation. ${ }^{5-7}$ This different pattern of abilities has been named the "WS cognitive profile" (WSCP). ${ }^{8}$

More than $95 \%$ of clinically defined WS patients have a de novo deletion of about 1.5 Mb, with the breakpoints clustered within two highly homologous regions flanking the WS region. ${ }^{9}$ Several genes have been mapped within the deleted region, ${ }^{10}$ including syntaxin $1 \mathrm{~A}(S T X 1 A)^{11}$ that codes for a component of the synaptic apparatus, and $R F C 2^{12}$ that encodes a subunit of the replication factor $\mathrm{C}$ complex.

While ELN haploinsufficiency has been associated with the cardiovascular and possibly connective tissue abnormalities of $\mathrm{WS},{ }^{13}$ the role of other genes in the remaining clinical features of the disease is not known. In particular, it is not clear which gene(s) is responsible for the cognitive and personality profile characteristic of WS patients. It has been reported ${ }^{8}$ that patients with deletions of only ELN and LIMKI show the characteristic WSCP, generally without mental retardation, but analysis of additional patients harbouring small deletions involving $E L N$ and $L I M K 1^{14}$ did not confirm these results. Limkl deficient mice exhibit significant abnormalities in spine morphology and synaptic function. They also show altered spatial learning and fear response. ${ }^{15}$ The CYLN2 gene, coding for the cytoplasmic linker protein CLIP- $115,{ }^{16}$ localised in the dendritic lamellar bodies of neurones and cerebellar glia cells, ${ }^{17}$ has also been considered a good candidate. Very recently, targeted mutation of Cyln2 has produced evidence that in the mouse haploinsufficiency of the gene produces brain abnormalities, hippocampal dysfunction, and particular deficits in motor coordination. ${ }^{18}$

We have identified a patient with many clinical features of WS and a peculiar cognitive profile, without specific spatial and constructive impairment, carrying a 7ql1.23 deletion with an atypical telomeric breakpoint.

\section{MATERIALS AND METHODS}

\section{Cytogenetic investigations}

Chromosome analysis was performed on the proband's blood using standard high resolution techniques. Fluorescent in situ hybridisation (FISH) with the commercially available probe WSR (Vysis Inc, Downers Grove, IL) was performed on the proband's metaphase spreads. Other FISH experiments were performed with bacterial artificial chromosome (BAC) and prokaryotic artificial chromosome (PAC) clones labelled with biotin-dUTP (Vector Laboratories, Burlingame, CA) using nick translation; the labelled probes were visualised with FITCavidin (Vector Laboratories) and the chromosomes were counterstained with DAPI (Sigma, Milano, Italy); hybridisations were analysed with a Zeiss Axioplan epifluorescence microscope and images captured with a Power Gene FISH System (PSI, Newcastle Upon Tyne, UK).

\section{Key points}

- We have identified a patient with a smaller deletion in the WS critical region and an atypical cognitive and behavioural profile.

- The patient had SVAS and vesicoureteric reflux with megaureter. He had normal development, with a mild delay in language acquisition.

- The subject's cognitive performance was compared to an age matched control group of nine WS subjects with a typical deletion (WSCG) and the results were significantly different for both general intelligence (borderline IQ $v$ mild impairment) and for visuospatial and visuoconstructive abilities (relatively preserved $v$ compromised). His cognitive profile did not show the usual WS cognitive and behavioural pattern. His development differs from both the WSCG and normally developing children.

- The patient's deletion ranges from the centromeric common breakpoint region to beyond marker D7S613 and includes elastin (ELN), LIMKI, and at least a portion of CYLN2.

- Our results suggest that deletion of CYLN2 may cause cognitive impairment, but is not sufficient to produce the typical WSCP. The GTF2I gene located in the telomeric portion of the WS critical region could be responsible for some of the cognitive and behavioural features of the disease.

\section{DNA analysis}

Microsatellite analysis was conducted on peripheral blood DNA extracted by standard techniques following the protocol described in Perez-Jurado et al. ${ }^{9}$ The portion of intron 1 of the CYLN2 gene containing the previously unreported 4 bp microsatellite polymorphism was amplified with primers CYLN2 ilf (5'-CTCTTCCCTTTCGGTTGTAAATGT-3', ABI-Fam labelled) and CYLN2 ilR (5'- CGCCTCCACCTGCCTCTTCT-3') and the same PCR protocol used for the other polymorphisms. All primers were purchased from MWG Biotech (Ebersberg, Germany). The $473 / 477 \mathrm{bp}$ fragments were visualised like all other polymorphisms on an ABI PRISM 310 Genetic Analyzer (Applera, Monza, Italy). The CYLN2 il polymorphism was verified in 50 unrelated normal subjects: 36 were 473/473, 13 $473 / 477$, and one was $477 / 477$. Allele frequencies were 0.85 for the $473 \mathrm{bp}$ allele and 0.15 for the $477 \mathrm{bp}$ allele. All sequencing reactions were performed with a Big Dye terminator cycle sequencing kit (Applera). Sequences were run on an ABI Prism 310 Genetic Analyzer.

\section{RESULTS}

\section{Clinical description}

The proband is a $5^{1 / 2}$ year old boy, the second child of healthy, unrelated parents. Written informed consent for the neuropsychological examination and the genetic analysis was obtained from his parents. The pregnancy was uneventful, 


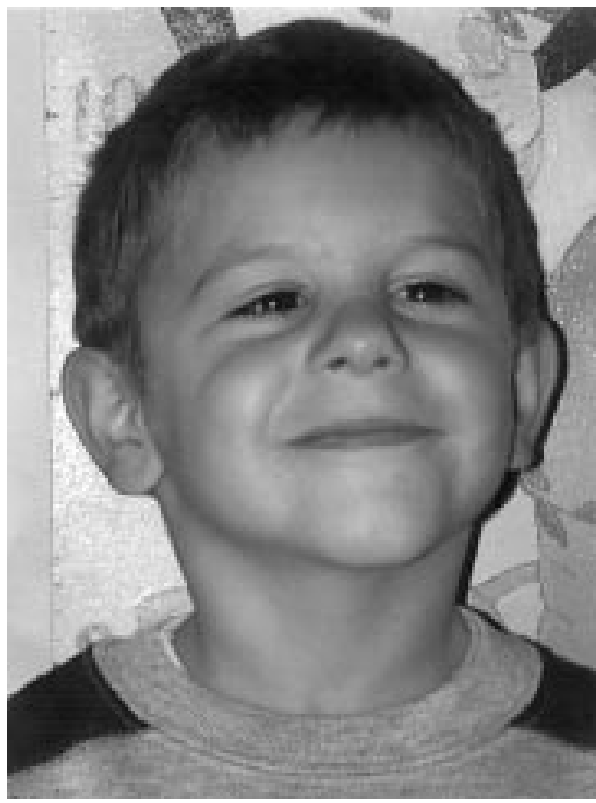

Figure 1 Photograph of the subject aged 51/2 years.

except for mild intrauterine growth retardation during the third trimester, shown by ultrasound examination. At birth the child's weight was $2450 \mathrm{~g}$ (25th centile), his length was 45 $\mathrm{cm}$ (3rd centile), and his head circumference was $34 \mathrm{~cm}$ (25th centile). His Apgar scores were 10/10. He had supravalvular aortic stenosis (SVAS, surgically corrected at the age of 23 months) and vesicoureteric reflux with right megaureter (surgically corrected at the age of 17 months). The following facial dysmorphism was evident: mild coarsening of facial features, bitemporal narrowing, sparse eyebrows, downward slanting palpebral fissures, deep set eyes, prominent cheeks, bulbous triangular nasal tip, long and featureless philtrum, and macrostomia (fig 1 ).

Neurological evaluation was normal, except for slightly decreased muscle tone, with hypertonia of the tibiotarsal joints and increased deep tendon reflexes. Balance was adequate.

\section{Neuropsychological testing}

The patient's psychomotor milestones were mildly delayed; he sat at the age of 8 months, walked at 12 months, and spoke his first words at 18 months and first sentences at 36 months. His cognitive profile was assessed at the age of $51 \frac{1}{2}$ years. We used a general intelligence test, the Stanford Binet Development
Scale, ${ }^{19}$ and a neuropsychological battery, VMI block construction $^{20}$ and Rey Figure, ${ }^{21}$ in order to assess visualspatial and visuoconstructive abilities; verbal and spatial working memory and recall memory for drawings were assessed respectively by Digit Span, Corsi Span, ${ }^{22}$ and Rey Figure Memory task (table 1). The subject showed borderline IQ $(\mathrm{IQ}=83)$, with some difficulties in vocabulary (mildly restricted), syntactic organisation (poor), and comprehension. His performance in visual-spatial and visuoconstructive tasks was borderline, like his IQ. Verbal and spatial working memory were mildly impaired, without significant differences between verbal and non-verbal domains. His social behaviour was friendly, and no anxiety trait or overfriendly manner could be detected.

The patient's performance was compared to a group of age matched subjects (six boys and three girls, mean age 5.12 years, SD 0.66) with Williams syndrome and the typical deletion (Williams syndrome Control Group, WSCG), who underwent the same test battery (table 1). The WSCG's performance was characterised by mild cognitive impairment ( $\mathrm{IQ}=68.67$, SD 16.29), major impairment in non-verbal abilities, mainly in visuoconstructive tasks, and a very low level of spatial organisation; verbal working memory was better than spatial. The WSCG displayed the typical Williams syndrome cognitive profile. The proband's and WSCG's test performances are compared in the last column of table 1. The difference in IQ was statistically significant. The patient's performance was similar to the WSCG in language tasks, but significantly better in spatial and constructive organisation. In fact the nine children of the WSCG were not able to perform the Rey Figure task (copy and memory), which is sensitive to the ability to organise spatially and hierarchically a graphic performance by first copying from a model and later recalling it, while the proband performed at a level adequate to his mental age.

Similar data were obtained from the second copy and draw test, the VMI test. No significant differences with the WSCG were shown by the other tests (block construction, Digit and Corsi Span).

\section{Genetic analysis}

FISH analysis using the commercially available probe WSR (Vysis) showed hemizygosity at the ELN, LIMK1, and D7S613 loci. FISH with clone CTB-8H17, partially overlapping the centromeric cluster of repeated sequences ${ }^{23}$ (BAC 1008H17), detected a partial deletion showing a small signal on one chromosome 7 compared to its homologue (fig 2A). The result was confirmed by performing a FISH analysis on a subject with typical WS deletion; the probe shows the same pattern as observed in our patient (fig 2B), as previously described. ${ }^{23}$ Additional FISH experiments with clones RP4-665P5 ${ }^{24}$ (fig $2 \mathrm{C}), \mathrm{RP} 11-815 \mathrm{~K} 3$, and CTB-139P11 ${ }^{25}$ gave signals of equal

Table 1 Neuropsychological test scores obtained from the proband, compared to the results obtained from a control group of nine WS subjects with typical deletion. The $p$ value (normal distribution) is shown in the last column; significant $p$ values $(p<0.05)$ are highlighted in bold

\begin{tabular}{lllll}
\hline \multirow{2}{*}{ Tests } & \multicolumn{2}{l}{ WS subjects with typical deletion } \\
\cline { 2 - 4 } & Average score & SD & scoband & \\
\cline { 2 - 4 } & & & score & \\
\hline Chronological age (y) & 5.12 & 0.66 & 5.60 & 0.4654 \\
Mental age (y) & 3.39 & 0.63 & 4.82 & $\mathbf{0 . 0 4 8 4}$ \\
IQ (score) & 68.67 & 16.29 & 83.00 & $\mathbf{0 . 0 1 6 6}$ \\
Corsi Span (score for years) & 3.60 & & 3.60 & \\
Digit Span (score for years) & 1.80 & 2.14 & 3.00 & 0.1595 \\
VMl (score for years) & 3.30 & 0.38 & 4.30 & $\mathbf{0 . 0 3 5 3}$ \\
Rey Figure copy (score for years) & Unmeasurable & & 4.60 & \\
Rey Figure memory (score for years) & Unmeasurable & & 4.60 & \\
Blocks - WISC-R (score) & 1.40 & 1.20 & 2.00 & 0.2934 \\
\hline
\end{tabular}



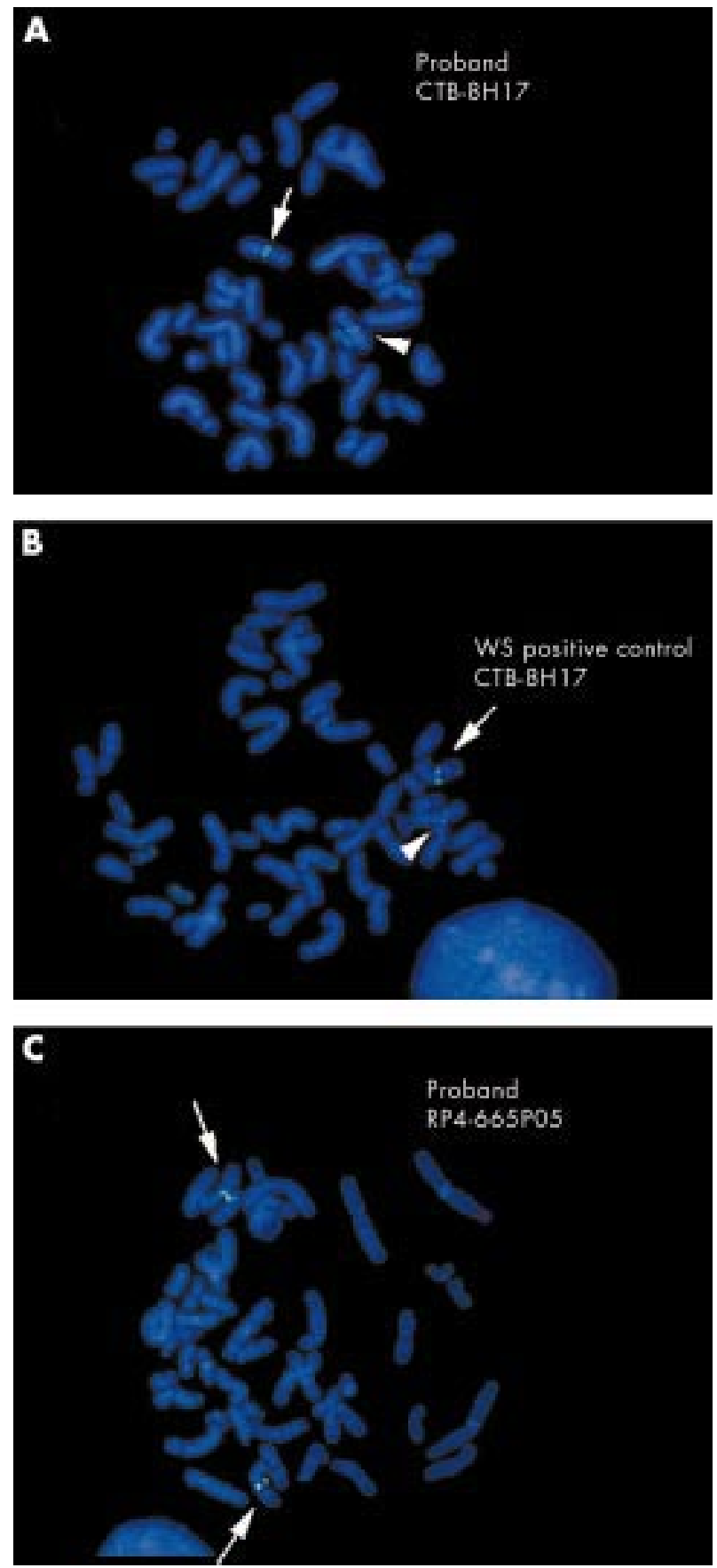

Figure $2 \mathrm{FISH}$ analysis of metaphase chromosomes from the patient $(A, C)$ and from a control subject with a typical WS deletion (B). In the patient (A), FISH with BAC clone CTB-8H17 generates a small signal on one chromosome 7 (arrowhead) compared to the other (arrow), indicating a partial deletion. The same result is obtained analysing a subject with a typical WS deletion (B). The clone CTB-8H17, partially overlapping the centromeric cluster of repeated sequences, gives a partial deletion pattern in subjects with the typical WS deletion, as described previously. ${ }^{23} \mathrm{FISH}$ with PAC probe RP5-665P05 (C) shows signals of equal intensity on both chromosomes 7 (arrows).

intensity on both chromosome 7 homologues, indicating absence of deletion.

Microsatellite analysis 9 on peripheral blood DNA from the patient, his brother, and his parents confirmed hemizygosity for marker D7S613 and the paternal origin of the deletion, but showed dizygosity for D7S1870. Markers D7S653, D7S1816, D7S489A, and D7S669 were also heterozygous. All other

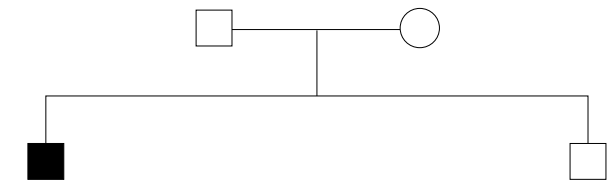

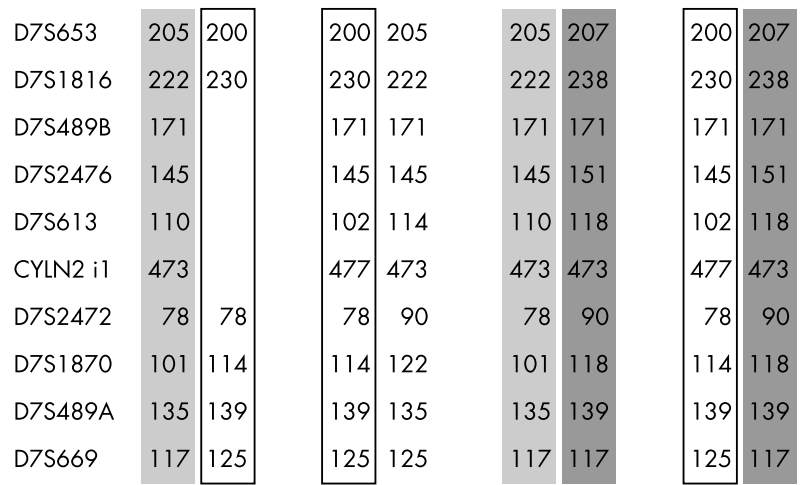

Figure 3 Molecular genotyping of the proband and his family with microsatellite probes in the WS region. The numbers indicate allele size in base pairs. Alleles belonging to the same haplotype have been vertically aligned and shaded. In the proband, markers D7S489B and D7S2476 have been drawn as deleted based on the FISH results with probe CTB-8H17; marker D7S2472 has been drawn as non-deleted because of FISH results with probe RP5-665P05; marker CYLN2 i1 has been considered deleted for the reasons outlined in the results section.

markers were uninformative (fig 3 ). The proband and his brother inherited different chromosome 7 haplotypes from their mother and the same haplotype from their father. In the proband the deletion was not associated with a recombination.

Typing of a previously undescribed 4 bp (TTCA) insertion/ deletion polymorphism in intron 1 of the CYLN2 gene ( $1066 \mathrm{bp}$ downstream of exon 1; position 11736822 on sequence NT_007758.8) showed that the proband's deletion includes at least the $5^{\prime}$ end of the gene. In fact, the proband and his brother inherited the same paternal haplotype carrying the 477 bp CYLN2 il allele, but the proband only has the $473 \mathrm{bp}$ allele (fig 3). He could have inherited his father's 473 bp allele only in the unlikely event of a double crossover. Sequence analysis of all $R F C 2^{12}$ and $C Y L N 2^{16}$ exons and of several intronic single nucleotide polymorphisms (SNPs) in the region (not shown) did not show any other informative polymorphism.

These results map the extent of the deletion from the typical WS breakpoint on the centromeric side to between intron 1 of CYLN2 and PAC clone RP4-665P5 on the telomeric side (fig $4)$.

\section{DISCUSSION}

The subject described here meets the diagnostic criteria for WS (clinical features, SVAS, short stature, positive FISH analysis), but his clinical and neuropsychological profiles are unusual. Face features are typical for WS, but more mildly expressed; moreover, inspection of photographs taken at different periods through infancy and childhood showed a gradual reduction of WS facial features (data not shown). The cognitive profile displayed by the patient was different in a number of ways from the WSCG. He had borderline IQ, while the age matched WSCG children were mildly impaired. He did not show the usual WS behavioural pattern. Moreover, his cognitive profile did not show the typical spatial and constructive impairment. However, the patient showed impairment in several competencies. In this sense, his development differs from both the WSCG and normally developing children. 

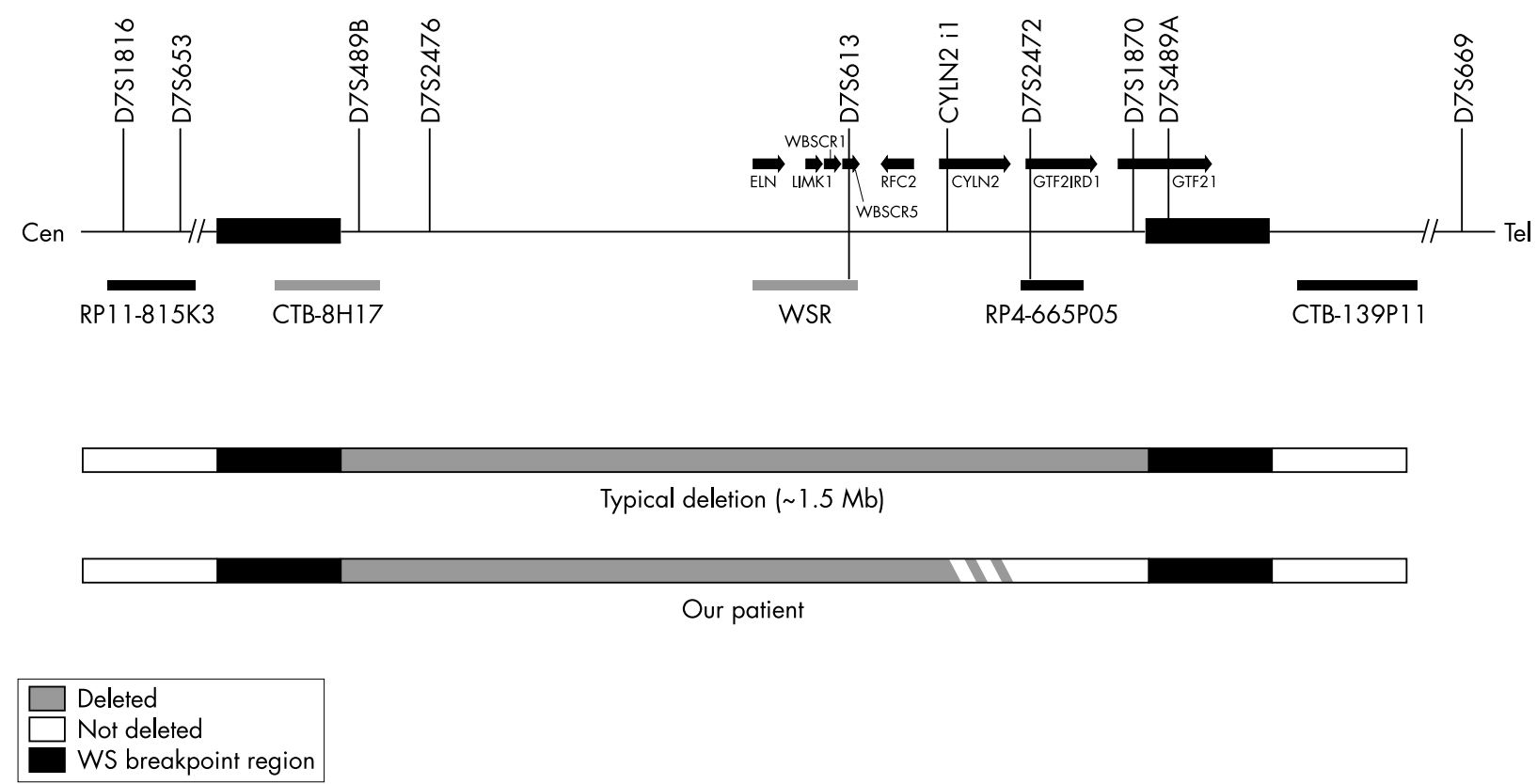

Figure 4 Physical map of the WS region at 7q11.23 (not drawn to scale) showing the relative location of the probes used for FISH analysis (thick horizontal lines), informative polymorphic markers (vertical lines), and selected genes (arrows).

Very few subjects with deletions that do not span the entire WS region have been reported so far. ${ }^{8}{ }^{23} 26-29$ Two patients carrying a deletion spanning from ELN to marker D7S1870 still had the full WS phenotype. ${ }^{26}$ Tassabehji et $a l^{14}$ and Karmiloff-Smith et $a^{28}$ accurately described a SVAS patient carrying a large deletion encompassing all genes in the WS region with the exception of CYLN2, GTF2IRD1, and GTF2I, but no clinical and cognitive WS phenotype. They used the British Abilities Scale II (BAS) scale for the assessment of cognitive abilities, and showed "an above average, even cognitive profile, with no indication of spatial impairment." Since there is no standardisation of the BAS scale for the Italian population, we used a different cognitive assessment, but explored the same functional areas.

Our patient's profile is different from that of the subject they described because of his borderline cognitive abilities but similar in the absence of the typical spatial constructive impairment. In the subject described by Korenberg et $a l^{23}$ (subject RM1199), all genes between FZD9 and WSCRI were deleted, while RFC2, CYLN2, GTF2IRD1, and GTF2I were not. This 8 year old girl had SVAS, some minor dysmorphisms, and mild mental retardation. No information on her cognitive or behavioural profile was available. Del Campo et $a^{29}$ reported a family with SVAS, borderline mental functioning, gregarious personality, minor facial WBS, and absence of visual/spatial deficits. Molecular analysis showed a $700 \mathrm{~kb}$ deletion including all genes from ELN to GTF2IRD1.

The GTF2I gene, located in the telomeric copy of the WS typical breakpoint region and deleted in all WS subjects with a typical deletion, ${ }^{30}$ is not deleted in our patient. This gene encodes BAP-135, a protein phosphorylated by Bruton's tyrosine kinase, as well as the transcription factor TFII-I. The centromeric copy of the WS breakpoint region contains a highly similar $(99.9 \%$ throughout the coding region) transcribed pseudogene, GTF2IP1. ${ }^{30}$ The GTF2IRDl gene, coding for a putative transcription factor with ubiquitous expression, ${ }^{31}{ }^{32}$ may also be preserved. All the other genes in the WS region are deleted.

We cannot rule out that in our patient CYLN2 may be expressed from an alternative promoter located downstream from the known exon 1 , since the transcription pattern of human CYLN2 has not been fully analysed and its protein coding region starts in exon $2 .{ }^{16}$ On the other hand, a deletion involving at least exon 1 and the entire upstream regulatory portion of the gene is likely to have major effects on its expression.

Tassabehji et al ${ }^{14}$ suggested that all determinants of the WS phenotype, apart from SVAS, lie telomeric to RFC2. Our observations indicate that, while the WS phenotype is the result of the haploinsufficiency of a number of genes, the deletion of the GTF2IRDI and/or GTF2I genes located on the telomeric side of the WS region is necessary for the syndrome's unique cognitive profile. Transgenic mice carrying a disrupted Gtf2irdl gene $^{33}$ did not show any obvious impairment, although it must be pointed out that they were not tested in detail for subtle cognitive and behavioural defects. It is also interesting to note that Osborne $e^{2}$ al $^{24}$ described a subject with WS facies, developmental delay, and WS-like behavioural profile (subject 12503) carrying an inversion of the WS region, and hypothesised that GTF2I may have been affected by the rearrangement. The GTF2I gene may then be critical for the WSCP.

Our data also show that hemizygosity for LIMKl and CYLN2, while not sufficient to generate the WSCP, may cause alterations in the cognitive profile. Very likely, deletion of GTF2I, GTF2IRD1, and CYLN2 (and perhaps LIMK1) is necessary to cause the typical WSCP. When, as in the case of our patient, one or more of these genes is preserved, the result is a milder phenotype, with some cognitive impairment (borderline IQ) and a variable loss of visual-spatial and constructive abilities.

Identification of additional subjects with atypical deletions, careful comparison of their genetic, clinical, and neuropsychological profiles, and the development of methods for the molecular analysis of GTF2I will be needed in order to assess the contribution of each gene to the WS phenotype.

\section{ACKNOWLEDGEMENTS}

The authors wish to thank the family of the patient for their cooperation, Lucy Osborne and Stephen Scherer for their gift of clones CTB139P1 1 and RP11-815K3, and Uberto Pozzoli, Maria Teresa Bassi, and Manuela Sironi for their helpful suggestions. This study was supported in part by grant ICS 030.10/RF97.37 from the Italian Ministry of Health 


\section{Authors' affiliations}

C Gagliardi, M C Bonaglia, R Borgatti, R Giorda, IRCCS "E Medea", Bosisio Parini, Lecco, Italy

A Selicorni, Clinica Pediatrica De Marchi, Milano, Italy

Correspondence to: Dr R Giorda, IRCCS "E. Medea", Via Don Luigi Monza 20, 23842 Bosisio Parini (LC), Italy; rgiorda@bp.Inf.it

\section{REFERENCES}

1 Morris CA, Demsey SA, Leonard CO, Dilts C, Blackburn BL. The natural history of Williams syndrome: physical characteristics. J Pediatr 1988; 113:318-26

2 Ewart AK, Morris CA, Atkinson D, Jin W, Sternes K, Spallone P, Stock $A D$, Leppert $M$, Keating MT. Hemizygosity at the elastin locus in a developmental disorder, Williams syndrome. Nat Genet 1993;5:11-16.

3 Lowery MC, Morris CA, Ewart A, Brothman L, Zhu XL, Leonard CO, Carey JC, Keating M, Brothman AR. Strong correlation of elastin deletions, detected by FISH, with Williams syndrome: evaluation of 235 patients. Am J Hum Genet 1995; 57:49-53.

4 Nickerson E, Greenberg F, Keating M, McCaskill C, Shaffer LG. Deletions in the elastin gene at $7 q 11.23$ occur in $~ 90 \%$ of patients with Williams syndrome. Am J Hum Genet 1995;56:1 156-61.

5 Udwin O, Yule W. A cognitive and behavioral phenotype in Williams syndrome. J Clin Exp Neuropsychol 1991;13:232-44.

6 Bellugi U, Wang P, Jernigan TL. Williams syndrome: an unusual neuropsychological profile. In: Broman S, Graffman J, eds. Atypical cognitive defects in developmental disorders: implications for brain function. Hillsdale, NJ: Lawrence Erlbaum, 1994:23-56.

7 Jarrold C, Baddeley AD, Hewes AK. Verbal and non-verbal abilities in the Williams syndrome phenotype: evidence for diverging developmental trajectories. J Child Psychol Psychiatry 1998;39:51 1-23.

8 Frangiskakis JM, Ewart AK, Morris CA, Mervis CB, Bertrand J, Robinson BF, Klein BP, Ensing GJ, Everett LA, Green ED, Proschel C, Gutowski NJ, Noble M, Atkinson DL, Odelberg SJ, Keating MT. LIM-kinase 1 hemizygosity implicated in impaired visuospatial constructive cognition. Cell 1996;86:59-69.

9 Perez-Jurado LA, Peoples R, Kaplan P, Hamel B, Francke U. Molecular definition of the chromosome 7 deletion in Williams syndrome and parent-of-origin on growth. Am J Hum Genet 1996:59:781-92.

10 Francke U. Williams-Beuren syndrome: genes and mechanisms. Hum Mol Genet 1999;8: 1947-54.

11 Osborne LR, Soder S, Shi XM, Pober B, Costa T, Scherer SW, Tsui LC. Hemizygous deletion of the syntaxin $1 \mathrm{~A}$ gene in individuals with Williams syndrome. Am J Hum Genet 1997:61:449-52.

12 Peoples R, Perez-Jurado L, Wang YK, Kaplan P, Francke U. The gene for replication factor $C$ subunit 2 (RFC2) is within the $7 q 11.23$ Williams syndrome deletion. Am J Hum Genet 1996;58:1370-3.

13 Ewart AK, Morris CA, Ensing GJ, Loker J, Moore C, Leppert M, Keating M. A human vascular disorder, supravalvular aortic stenosis, maps to chromosome 7. Proc Natl Acad Sci USA 1993;90:3226-30.

14 Tassabehii M, Metcalfe K, Karmiloff-Smith A, Carette M, Grant J, Dennis N, Reardon W, Splitt M, Read AP, Donnai D. Williams syndrome: use of chromosomal microdeletions as a tool to dissect cognitive and physical phenotypes. Am J Hum Genet 1999;64:118-25.

15 Meng Y, Zhang Y, Tregoubov V, Janus C, Cruz L, Jackson M, Lu WY, MacDonald JF, Wang JY, Falls DL, Jia Z. Abnormal spine morphology and enhanced LTP in LIMK-1 knockout mice. Neuron 2002;35:121-33.

16 Hoogenraad CC, Eussen BH, Langeveld A, van Haperen R, Winterberg $\mathrm{S}$, Wouters CH, Grosveld F, De Zeeuw Cl, Galiart N. The murine CYLN2 gene: genomic organization, chromosome localization, and comparison to the human gene that is located within the $7 q 11.23$ Williams syndrome critical region. Genomics 1998;53:348-58
17 De Zeeuw CI, Hoogenraad CC, Goedknegt E, Hertzberg E, Neubauer A, Grosveld F, Galjart N. CLIP-1 15, a novel brain-specific cytoplasmic linker protein, mediates the localization of dendritic lamellar bodies. Neuron 1997;19:1 187-99.

18 Hoogenraad CC, Koekkoek B, Akhmanova A, Krugers H, Dortland B, Miedema $M$, van Alphen A, Kistler WM, Jaegle $M$, Koutsourakis $M$, Van Camp N, Verhoje M, van der Linden A, Kaverina I, Grosveld F, De Zeeuw Cl, Galjart N. Targeted mutation of Cyln2 in the Williams syndrome critical region links CLIP-1 15 haploinsufficiency to neurodevelopmental abnormalities in mice. Nat Genet 2002:32:116-27.

19 Bozzo MT, Mansueto ZG. Adattamento Italiano della Scala di Intelligenza Stanford-Binet forma L-M, nella Revisione Terman-Merrill (Italian Version L-M form, III revision). Firenze, Italy: Organizzazioni Speciali, 1993

20 Beery KE, Buktenica NA. Developmental test of visual motor integration. Student test booklet. Chicago: Follett Publishing, 1967.

21 Rey A. Reattivo della figura complessa. Firenze: Organizzazioni Speciali, 1968

22 Corsi PM. Human memory and the medial temporal region of the brain. Unpublished PhD thesis, McGill University, Montreal, 1972

23 Korenberg JR, Chen XN, Hirota H, Lai Z, Bellugi U, Burian D, Roe B, Matsuoka R. Genome structure and cognitive map of Williams syndrome. I Clin Neurosci 2000:12:89-107.

24 Peoples R, Franke Y, Wang YK, Perez-Jurado L, Paperna T, Cisco M, Francke U. A physical map, including a BAC/PAC clone contig, of the Williams-Beuren syndrome-deletion region at 7q1 1.23. Am J Hum Gene 2000:66:47-68

25 Osborne LR, Li M, Pober B, Chitayat D, Bodurtha J, Mandel A, Costa T, Grebe T, Cox S, Tsui LC, Scherer SW. A 1.5 million-base pair inversion polymorphism in families with Williams-Beuren syndrome. Nat Genet 2001;29:321-5

26 Botta A, Novelli G, Mari A, Novelli A, Sabani M, Korenberg J, Osborne LR, Digiglio MC, Giannotti A, Dallapiccola B. Detection of an atypical $7 q 11.23$ deletion in Williams syndrome patients which does not include the STXIA and FDZ3 genes. J Med Genet 1999;36:478-80.

27 Olson TM, Michels VV, Urban Z, Csiszar K, Christiano AM, Driscoll DJ, Feldt RH, Boyd CD, Thibodeau SN. A 30 kb deletion within the elastin gene results in familial supravalvular aortic stenosis. Hum Mol Genet 1995; 4 : 1677-9.

28 Karmiloff-Smith A, Grant J, Ewing S, Carette M, Metcalfe K, Donnai $D$, Read AP, Tassabehii M. Using case study comparisons to explore genotype-phenotype correlations in Williams-Beuren syndrome. J Med Genet 2003;40:136-40

29 Del Campo M, Magano LF, Martinez Iglesias J, Perez Jurado LA. Partial features of Williams-Beuren syndrome in a family with a novel $700 \mathrm{~kb}$ $7 q 11.23$ deletion. 10th International Congress of Human Genetics, Vienna 2001: Abstract C055.

30 Perez-Jurado LA, Wang YK, Peoples R, Coloma A, Cruces J, Francke $U$. A duplicated gene in the breakpoint regions of the $7 q 11.23$ Williams-Beuren syndrome deletion encodes the initiator binding protein TFIII and BAP-135, a phosphorylation target of BTK. Hum Mol Genet 1998:7:325-34

31 Osborne LR, Campbell T, Daradich A, Scherer SW, Tsui LC. Identification of a putative transcription factor gene (WBSCR 1 1) that is commonly deleted in Williams-Beuren syndrome. Genomics 1999:57:279-84.

32 Franke Y, Peoples R, Francke U. Identification of GTF2IRD 1, a putative transcription factor within the Williams-Beuren syndrome deletion at 7q11.23. Cytogenet Cell Genet 1999;86:296-304.

33 Durkin ME, Keck-Waggoner CL, Popescu NC, Thorgelrsson SS Integration of a c-myc transgene results in disruption of the mouse Gtf2ird 1 gene, the homologue of the human GTF2IRD1 gene hemizygously deleted in Williams-Beuren syndrome. Genomics 2001;73:20-7.

\title{
High frequency of T9 and CFTR mutations in children with idiopathic bronchiectasis
}

\author{
V N Ninis, M O Kýlýnç, M Kandemir, E Daðlý, A Tolun
}

$\mathrm{O}$ bstructive pulmonary disease is an important health problem in all populations, and bronchiectasis of unknown aetiology (idiopathic bronchiectasis, IB) contributes significantly to the disease. The gene responsible for cystic fibrosis (CF), the cystic fibrosis transmembrane regulator (CFTR), was shown to have a role in the manifestation of IB, as gene mutations and a significantly high proportion of allele T5 of the polythymidine tract $\left(\mathrm{T}_{\mathrm{n}}\right)$ in intron 8 (IVS8) have been observed in patients. ${ }^{1-5}$ However, the complex genetic basis of the phenotype expression of IB remains largely unknown. CFTR mutations alone cannot be held responsible for the disease, as obligate CFTR mutation heterozygotes were shown not to have 


\section{Key points}

- We performed genetic analysis at the CFTR locus in 73 unrelated Turkish families affected with idiopathic bronchiectasis. Twenty-eight of the unrelated affected children were found to carry mutations, six of them on both CFTR chromosomes.

- We detected a total of nine different mutations in 34 of the 146 alleles $(23.3 \%)$. The most frequent mutation was $\mathrm{K} 68 \mathrm{E}$, which we had previously identified as a rare novel mutation in a CF patient. The spectrum of mutations was very different from those observed in our CF patients. Also, the spectrum of polymorphic alleles was different from both the Turkish CF patients and the normal population.

- Frequencies of alleles T5 and T9 were highly significant compared to the normal population. T9 had not been reported to be frequent in IB patient groups from other populations and not reported to be associated with any disease. Association of $470 \mathrm{M}$, but not a specific $(T G)_{m}$ allele, with T9 was also highly significant.

- Genotypic homozygosity at the locus was very low, in spite of the high parental consanguinity. Also, all four IB sib pairs and six of the IB healthy sib pairs shared genotypes.

- We suggest that either a modifier gene works in concert with CFTR mutations and polymorphisms to manifest the IB phenotype or T9 works as an attenuator for CF.

an increased risk for IB. ${ }^{6}$ The CFTR gene seems to act in a multifactorial context, as both the mutations and polymorphic alleles exert their effects in an incompletely penetrant fashion. Therefore, environmental factors and/or other genes are believed to contribute to the disease. IB is only one of the several single organ diseases to which the CFTR gene contributes. Some other such diseases are asthma, ${ }^{7}$ obstructive azoospermia, ${ }^{8-11}$ allergic bronchopulmonary aspergillosis, ${ }^{12}$ and idiopathic chronic pancreatitis. ${ }^{13}$

Recently we conducted an extensive molecular genetic investigation at the CFTR locus in CF patients and showed that the Turkish population had the highest genetic heterogeneity among those studied so far. We also found that CF was quite common, with a carrier frequency of about 1 in $50 .{ }^{15}$ We now report the genetic analysis of the CFTR gene in Turkish children diagnosed with idiopathic bronchiectasis. What set our study apart from the previous studies are the large number of IB patients, the very high proportion of families with parental consanguinity, and the high consanguinity in the population. High consanguinity highlights the contribution of genetic factors.

\section{MATERIALS AND METHODS \\ Patients and families}

In total, 77 children with IB from 73 unrelated families were included in the study. Eight of the patients were sib pairs. Forty-five of the patients were girls and 32 were boys. DNA samples were available from the great majority of patients' parents and 51 healthy sibs. Thirty-eight patients had no sibs available for study, while 23 had one healthy sib each, nine had two, two had three, and one had four. There were no twins in the study group. Appropriate informed consent was obtained from the families.

The status of parental consanguinity was known in 52 of the families: 27 declared consanguinity (19 were first cousin marriages) and 25 denied it. Two parent pairs in the latter group had originated from the same village, thus some degree of consanguinity could not be excluded.

\section{Clinical findings}

Bronchiectasis was diagnosed by computed tomography scan or bronchography. Primary ciliary dyskinesia, $\alpha_{1}$-antitrypsin deficiency, and immunodeficiency were excluded as the cause of the disease. Patients had no other clinical findings such as malabsorption or sinus disease and had normal to borderline sweat chloride values $(<60 \mathrm{mEq} / \mathrm{l})$. Eleven of the patients were diagnosed as borderline CF late in the study. Broad clinical information was available for 46 of the patients, 30 girls and 16 boys. These patients had a mean age of 10.3 (SD 3.9) years at the time of the last clinical examination, and the disease manifested at 1 month to 12 years (mean 31.7, SD 44 months). In 12 of them the disease was disseminated. In the rest, it was localised most commonly in the lower left lobe (15), followed by lower right (9), and both lower lobes (8). Bronchiectasis was not localised in an upper lobe in any patient. Seven of the 46 patients had undergone lobectomy, while three others exhibiting a severe clinical course had been assessed in need of but unsuitable for operation. Eleven of the patients had chronic persistent cough and in 25 patients coughing was productive. Ten patients complained only of sputum production. One patient had haemoptysis, five had chest deformity, and 13 had clubbing. Pulmonary function tests were performed in 33 patients above the age of 6 years. The average forced vital capacity (FVC) was $72.6 \%$ (SD 23.8) and the forced expiratory volume in one second (FEVI) $68.5 \%$ (SD 24.1).

\section{Mutation analysis}

The methods have been described in detail by Kýlýnç et al. ${ }^{15}$ Briefly, all 27 exons of the CFTR gene and the flanking intronic sequences were amplified by polymerase chain reaction (PCR) and analysed by denaturing gradient gel electrophoresis (DGGE). ${ }^{16}$ Any pattern variation was investigated by comparing it to known DNA variant marker patterns, and, when necessary, by subsequent DNA sequence analysis. Amplification primers were kindly supplied by Professor M Goossens on behalf of the European Concerted Action for Coordination of Cystic Fibrosis Research and Therapy (ECACF). In addition, patients were screened for five mutations not detectable by the DGGE analysis described above. They were intronic mutations $3849+10 \mathrm{kbC}>\mathrm{T}^{18}$ and $1811+1.6 \mathrm{kbA}>\mathrm{G},{ }^{19}$ deletion mutations CFTRdele2, $3^{20}$ and CFTRdele19 ${ }^{21}$, and $-33 \mathrm{~A}>\mathrm{G}$ in the minimal promoter region. $^{22}$ Marker DNA samples for the latter region were kindly provided by Dr M Claustres. E1228G was identified by sequence analysis in an $\mathrm{ABI} 310$.

\section{Haplotype analysis}

Patients and family members were assayed for a total of six intragenic DNA polymorphisms, five intronic and one exonic, as described previously. ${ }^{15}$ The three alleles (T5, T7, and T9) of $\mathrm{T}_{\mathrm{n}}$ were amplified by allele specific PCR. ${ }^{3}$ Reliability of the technique was ascertained by verification by another method that involved nested PCR amplification, cleavage with a restriction enzyme at the created site, and size determination on $8 \%$ polyacrylamide gels. ${ }^{9}$ The alleles for the $(\mathrm{TG})_{\mathrm{m}}$ tract upstream of $\mathrm{T}_{\mathrm{n}}$ that were associated with alleles $\mathrm{T} 5$ and $\mathrm{T} 9$ were determined by allele specific PCR amplification and size determination on $8 \%$ polyacrylamide gels. Polymorphism $470 \mathrm{M} / \mathrm{V}(\mathrm{A} / \mathrm{G}$ variation at nucleotide 1540 in exon 10) was assayed by either DGGE or restriction enzyme digestion. ${ }^{23}$ The alleles for the biallelic GATT repeat in intron 6 and the three multiallelic microsatellites (IVS8CA in intron 8 and IVS17bTA and IVS17bCA in intron 17b) were resolved on polyacrylamide gels. ${ }^{24-26}$ Haplotypes were constructed by segregation analysis using the available DNA samples from parents and sibs.

\section{Statistical analysis}

$\chi^{2}$ test was applied to contingency tables to detect statistically significant differences in allele frequencies ${ }^{27} ; p$ values of less 
Table 1 The CFTR mutations identified in 73 unrelated IB patients

\begin{tabular}{|c|c|c|}
\hline Mutation & No of alleles & Consequence \\
\hline K68E & 9 & Lys to Glu at 68 \\
\hline$-33 G>A$ & 7 & Promoter mutation \\
\hline N1303K & 6 & Asn to Lys at 1303 \\
\hline CFTRdele 19 & 4 & $\begin{array}{l}\text { Deletion of exon } 19 \\
\text { Frameshift }\end{array}$ \\
\hline $3272-26 A>G$ & 3 & mRNA splicing defect \\
\hline CFTRdele2,3 & 2 & $\begin{array}{l}\text { Deletion of exons } 2 \text { and } 3 \\
\text { Frameshift }\end{array}$ \\
\hline F1052V & 1 & Phe to Val at 1052 \\
\hline E1228G & 1 & Glu to Gly at 1228 \\
\hline W1282X & 1 & Trp to Stop at 1282 \\
\hline Total alleles & 34 & \\
\hline
\end{tabular}

than 0.05 were considered to indicate significance and less than 0.01 high significance.

\section{RESULTS}

In total, 69 unrelated children and four sib pairs with the IB phenotype were screened for mutations in the CFTR gene. Mutations were identified in 28 of the unrelated patients. Nine different mutations were identified in $34(23.3 \%)$ of the 146 CFTR chromosomes analysed. Five patients were homozygous for CFTR mutations, one each for 3272-26A>G, N1303K, and CFTRdele19, and two for K68E. Another patient was a compound heterozygote for $-33 \mathrm{~A}>\mathrm{G}$ and CFTRdele2,3. Twenty-two patients carried one mutation each. The chromosomal backgrounds were determined, and CFTR haplotypes were constructed to assess identity by descent. The frequencies of T9 and T5 as well as whether any alleles of $470 \mathrm{M} / \mathrm{V}$ and $(\mathrm{TG})_{\mathrm{m}}$ were associated significantly were investigated by comparing our CF patient group and the normal control group reported previously. ${ }^{15}$

\section{Spectrum of mutations}

The mutations detected at the CFTR locus in the IB patients and their frequencies are shown in table 1 . The most frequent mutation was K68E (nine of the total 34 mutant chromosomes), a mutation we recently identified in a Turkish CF patient. ${ }^{15}$ The next most frequent mutations were $-33 \mathrm{G}>\mathrm{A}$ and N1303K, observed on seven and six chromosomes, respectively, and 3272-26A $>\mathrm{G}$ was found on three chromosomes. Large deletion mutations CFTRdele 19 and CFTRdele2,3 were observed in four and two chromosomes, respectively. One patient had W1282X and another F1052V, while the last one had the novel mutation E1228G, which resulted from an A to $\mathrm{G}$ transition at nucleotide 3815 (sequence data available on request). An uncharged polar amino acid was substituted for an acidic one at residue 1228 in exon 19 in the second nucleotide binding domain of the protein. The residue has been conserved in human, bovine, Xenopus, and dogfish. ${ }^{28}$ No other mutant allele was identified upon screening for the two intronic mutations $3849+10 \mathrm{kbC}>\mathrm{T}$ and $181 \mathrm{l}+1.6 \mathrm{kbA}>\mathrm{G}$, which were reported to be quite common in southern Mediterranean populations. ${ }^{18} 19$

The spectrum of mutations and their frequencies differed from those in our CF patient group. F508del, 1677-1678delTA, $2183 \mathrm{AA}>\mathrm{G}$, and G542X, the most common four mutations in our CF patients comprising 52\% (64/125) of all mutant chromosomes, ${ }^{15}$ were not observed at all in the IB group. Only four of the total of nine different mutations we found in the IB group were also found in the $166 \mathrm{CF}$ chromosomes we had analysed. ${ }^{15}$ The numbers in CF patients were as follows: one K68E, four N1303K, one CFTRdele2,3, and five W1282X. Three of the remaining IB mutations $(3272-26 \mathrm{~A}>\mathrm{G}$, CFTRdele19,
F1052V) were identified in other studies in CF patients, ${ }^{16} 2129$ one $(-33 G>A)$ in a CBVAD patient, ${ }^{22}$ and the last one (E1228G) in this study.

\section{Significance of the allelic frequencies at three polymorphic loci}

Certain alleles of $\mathrm{T}_{\mathrm{n}}$ and $(\mathrm{TG})_{\mathrm{m}}$ and allele $470 \mathrm{M}$, alone or in association with others, have been implicated in the aetiology of bronchiectasis. ${ }^{13}{ }^{4}$ We investigated whether any alleles were associated with IB in our patients. We had found the frequencies of T9, T7, and T5 in the normal chromosomes to be 28 , 162 , and 10 , respectively, in a total of $200 .{ }^{15}$ We found the frequencies of T9, T7, and T5 in the IB chromosomes in which no mutation was identified (no mutation chromosomes) to be 71 , 30 , and 11, respectively, in 112. The frequency of T5 with respect to T7 in the IB no mutation chromosomes was found to be highly significant compared to the normal population (11/41 versus 10/172). The frequency of T9 with respect to T7 in no mutation IB chromosomes also was significantly higher than in the normals (71/101 versus 28/190). Regarding the IB chromosomes harbouring mutations, we found the frequencies of T9, T7, and T5 to be 20, 13, and 1, respectively, in 34 . Thus, the frequency of $\mathrm{T} 9$ with respect to $\mathrm{T} 7$ was highly significant (20 versus 13) as compared to the CF mutant chromosomes (17 versus 102$).^{15}$

The frequency of $470 \mathrm{M}$ was similar in the normal T9 chromosomes (13/28) and the normal T7 (66/157). Similarly, the difference in the association of $470 \mathrm{M}$ between the T7 IB no mutation chromosomes (16/29) and the T7 normals (66/157) did not reach significance. However, T9 no mutation IB chromosomes had a highly significant association with $470 \mathrm{M}$ in comparison to the T9 normals (44/70 versus 13/28). In addition, while all of the 10 normal $\mathrm{T} 5$ alleles were associated with $470 \mathrm{M}$, five of 11 IB T5 no mutation chromosomes were on $470 \mathrm{~V}$ background.

The frequencies of the $(\mathrm{TG})_{\mathrm{m}}$ alleles were similar in T9 IB no mutation chromosomes (58 TG9 and 13 TG11) and normal T9 chromosomes (24 TG9 and four TG11). In contrast, the association with the T5 chromosomes was different: seven of the T5 IB no mutation chromosomes were on TGll background and four on TG13, while all of the 10 normals were on TG11.

In summary, $\mathrm{T} 9$ showed a highly significant association with the disease, and 470M was highly significant in the T9 no mutation IB chromosomes. Allele T5 also showed a highly significant association with the disease and increased association with both TG13 and 470V.

\section{Haplotypes}

Haplotypes could be determined in 71 of the unrelated patients with respect to the alleles at the polymorphic loci $(\mathrm{GATT})_{n}, \mathrm{~T}_{\mathrm{n}}$, and $470 \mathrm{M} / \mathrm{V}$, rare polymorphisms detected in the course of mutation screening, and mutations. Also, the $(\mathrm{TG})_{\mathrm{m}}$ alleles associated with the T5 and T9 alleles were determined. We later refined the haplotypes by analysing three microsatellite loci. A large number of different haplotypes were observed: 22 among the total of 34 with mutations and 53 among the total of 112 without mutations.

The T5 IB chromosomes also showed great variation as compared to normals. There were $10 \mathrm{~T} 5$ chromosomes among the 200 normals, and they were all on GATT7-TG11-470V background. Moreover, they had in total only three different haplotypes with respect to the three microsatellite polymorphisms IVS8CA, IVS17bTA, and IVS17bCA: 14-30-13, 17-3013 , and 17-33-13 with frequencies of 3,3, and 4, respectively. In contrast, T5 IB chromosomes were mostly on backgrounds GATT7-TG11-470M (five of 12) and GATT6-TG13-470V (four of 12). The remaining three haplotypes were observed once: GATT6-TG11-470M, GATT7-TG11-470V-1001+11T-2694T4002G, and GATT7-TG13-470V-F1052V-2694T. When the three microsatellites were also taken into account, no two of the T5 IB chromosomes had the same haplotype. 


\begin{tabular}{|c|c|c|c|c|c|c|}
\hline $\begin{array}{l}\text { IVS8 } \\
(\text { TG })_{m}\end{array}$ & IVS8 $(T)_{n}$ & Polymorphism & Mutation & $\begin{array}{l}\text { No of } \\
\text { chroms }\end{array}$ & $\begin{array}{l}\text { No of heterozyg } \\
\text { patients }\end{array}$ & $\begin{array}{l}\text { No of homozyg } \\
\text { patients }\end{array}$ \\
\hline 11 & 5 & $470 M$ & - & 6 & 4 & 1 \\
\hline \multirow[t]{3}{*}{13} & 5 & $470 \mathrm{~V}$ & - & 4 & 0 & 2 \\
\hline & 7 & $470 M$ & - & 10 & 8 & 1 \\
\hline & 7 & $470 \mathrm{~V}$ & - & 10 & 8 & 1 \\
\hline 9 & 9 & $470 \mathrm{M}$ & - & 40 & 26 & 7 \\
\hline 11 & 9 & $470 M$ & - & 4 & 4 & 0 \\
\hline 9 & 9 & $470 \mathrm{~V}$ & - & 17 & 11 & 3 \\
\hline 11 & 9 & $470 \mathrm{~V}$ & - & 8 & 8 & 0 \\
\hline 11 & $7 / 9$ & $470 \mathrm{M} / \mathrm{V}$ & - & 2 & 0 & (1) \\
\hline \multirow[t]{6}{*}{11} & 5 & $\begin{array}{l}470 \mathrm{~V}, 2694 \mathrm{~T} \\
1001+11 \mathrm{~T}, 4002 \mathrm{G}\end{array}$ & - & 1 & 1 & 0 \\
\hline & 7 & $\begin{array}{l}470 \mathrm{~V}, 2694 \mathrm{~T} \\
875+40 \mathrm{G}\end{array}$ & - & 1 & 1 & 0 \\
\hline & 7 & $470 \mathrm{~V}, 2694 \mathrm{~T}$ & - & 1 & 1 & 0 \\
\hline & 7 & $470 V, 2694 \mathrm{~T}$ & - & 1 & 1 & 0 \\
\hline & 7 & $470 \mathrm{M}, 1001+11 \mathrm{~T}$ & - & 1 & 1 & 0 \\
\hline & 7 & $470 M, 875+40 G$ & - & 5 & 3 & 1 \\
\hline 9 & 9 & $470 \mathrm{~V}, 2694 \mathrm{~T}$ & - & 1 & 1 & 0 \\
\hline \multirow[t]{8}{*}{13} & 5 & $470 \mathrm{~V}, 2694 \mathrm{~T}$ & F1052V & 1 & 1 & 0 \\
\hline & 7 & $470 M$ & CFTRdele 19 & 2 & 2 & 0 \\
\hline & 7 & $470 \mathrm{~V}$ & CFTRdele 19 & 2 & 0 & 1 \\
\hline & 7 & $470 M$ & W1282X & 1 & 1 & 0 \\
\hline & 7 & $470 \mathrm{~V}$ & CFTRdele2,3 & 2 & 2 & 0 \\
\hline & 7 & $470 M$ & E1228G & 1 & 1 & 0 \\
\hline & 7 & $470 M$ & $-33 G>A$ & 2 & 2 & 0 \\
\hline & 7 & $470 V$ & $-33 G>A$ & 3 & 3 & 0 \\
\hline 9 & 9 & $470 \mathrm{~V}$ & $-33 G>A$ & 2 & 2 & 0 \\
\hline 9 & 9 & $470 M$ & $\mathrm{~K} 68 \mathrm{E}$ & 9 & 5 & 2 \\
\hline 9 & 9 & $470 \mathrm{~V}$ & N1303K & 4 & 4 & 0 \\
\hline 9 & 9 & $470 M$ & N1303K & 2 & 0 & 1 \\
\hline 9 & 9 & $470 \mathrm{~V}$ & $3272-26 A>G$ & 1 & 1 & 0 \\
\hline 9 & 9 & $470 M$ & $3272-26 A>G$ & 2 & 0 & 1 \\
\hline
\end{tabular}

\section{Comparison of the genotypes of the sibs}

We compared the CFTR haplotypes of the patients to their sibs (table 2). All of the four affected sib pairs shared both of their haplotypes, indicating that both of the CFTR chromosomes contributed to the phenotype. The genotypes were T9N1303K homozygous, T9/T9-N1303K, T9/T9-3272-26A>G, and T7/T5. However, six affected-healthy sib pairs also shared both of the haplotypes, excluding the gene as the sole locus responsible for the disease phenotype. The genotype of one pair was T7/T7-CFTRdele19, three were T9/T9, and two were T9/T7.

\section{Identity by descent}

The haplotypes were evaluated to assess identity by descent. In total, nine patients exhibited haplotype homozygosity, three with mutations and six with no mutation detected. The family of one of them had declared parental consanguinity and of four others had denied it. Patients from 26 other families who had claimed parental consanguinity (including 18 first cousin marriages) were not homozygous.

\section{DISCUSSION}

CFTR mutations were identified in $23.3 \%$ (34/146) of the CFTR chromosomes in our 73 unrelated idiopathic bronchiectasis patients. This frequency is very high, as the carrier frequency in our population was assessed as $1 / 50{ }^{15}$ It was intriguing that F508del was not observed in our IB patients, although it is the most common mutation (23.5\% of the mutant chromosomes) in our CF patients. ${ }^{15}$ This mutation comprised three of the mutant alleles among the total of 19 detected in the adult Italian disseminated bronchiectasis patients, ${ }^{30}$ three of 16 in the French patients, ${ }^{2}$ and two of seven in the Greek mostly adult patients. ${ }^{5}$ Conversely, three of the mutations in our IB patients
(3272-26A>G, CFTRdele19, and $-33 \mathrm{~A}>\mathrm{G}$ ) were not carried by any of our CF patients ${ }^{15}$ (this study). Also, none of the mutations detected in our IB patients was found in the French, Italian, or Greek IB patients. This was surprising since N1303K and 3272$26 \mathrm{~A}>\mathrm{G}$ are both common CF mutations in most Mediterranean countries. K68E, the most common mutation in our IB group, was observed only once in the 166 CF chromosomes we had analysed. It manifested a very mild phenotype. ${ }^{15}$ It has been reported in only one other person, a CF patient in north eastern Italy. $^{31}$ The next most common mutation/gene variation, $-33 \mathrm{~A}>\mathrm{G}$, had been identified on a CBAVD chromosome, out of 159 CBAVD, $376 \mathrm{CF}$, and 238 normal chromosomes, and was proposed to be either a rare polymorphism or a mutation that affected the regulation of the gene. ${ }^{22}$ We detected it in seven of the 146 IB chromosomes, but not in any of the 41 CF no mutation chromosomes or 44 control samples. Therefore, we propose that it is a pathogenic mutation, but perhaps associated with CBAVD, IB, or mild CF. It was associated in trans with either T5 (two patients), T7 (four patients), or T7-CFTRdele2,3 (one patient), but in no case with T9. The next most common mutations were N1303K and CFTRdele19, both of which manifest severe CF phenotypes. ${ }^{21}{ }^{32}$ These five mutations make up $85.3 \%$ (29/34) of all mutant IB chromosomes, and 20 of these 29 chromosomes were on TG9-T9 background. It is worth mentioning here that in our population F508del is mostly on T7 background: 38 of the total 39 F508del chromosomes we had analysed were on this background. ${ }^{15}$ Also interesting was that all of the three 3272-26A>G mutant alleles in our IB patients were on T9 background in contrast to the European alleles which were all on T7 background. ${ }^{33}{ }^{34}$ All of these observations point to a role of T9 in the aetiology of IB.

In assessing the significance of T9 and T5, we compared their frequencies to those of $\mathrm{T} 7$, since it is the most common allele 
world wide and has not been implicated in any kind of pathogenesis. Alleles T5 and T9 both showed a highly significant association with IB, and 470M was similarly associated with the T9 IB chromosomes. T5 was shown to be high also in the Italian patients (mean age 53 (SD 15.8)), ${ }^{4}$ but not in two French and one Greek mostly adult patient group. ${ }^{25}{ }^{35}$ In addition, the T5 chromosomes in our IB patients were mostly on backgrounds TG11-470V and TG13-470M, whereas the normal T5 chromosomes were all on TG11-470M. Thus, the IB chromosomes all deviated from TG11-470M. This was not surprising, since the association of both $470 \mathrm{~V}$ and a low number of TG repeats have been shown to lead to lower gene activity. ${ }^{36}$ The $470 \mathrm{M}$ allele leads to a higher protein activity, $470 \mathrm{M}$ protein having 1.7 -fold intrinsic chloride channel activity compared to that of $470 \mathrm{~V}$ in transfected cells, and the lower the $(\mathrm{TG})_{\mathrm{m}}$ repeat number, the less the proportion of the mRNA lacking exon 9 sequences transcribed from T7 CFTR chromosomes in transfected cells. Noone $e t a l^{37}$ studied a patient who had CF type lung disease with normal to borderline sweat chloride values and was homozygous for haplotype T5-TG12-470V. She had defective CFTR mediated chloride conductance in epithelia.

In addition to confirming the previous findings on increased frequencies of CFTR mutations and T5 in IB patients, ${ }^{1-5}$ this report highlights $\mathrm{T} 9$, an allele that had not been reported previously in association with any disease. Despite the fact that this allele results in normal transcripts (not lacking exon 9), it is not the most common allele in the normal population world wide, thus is not the most common allele. The high frequency of T9 chromosomes in our patients cannot be attributed to a possible association with an as yet unidentified common mutation, because the allele was on a large number of different haplotypes. We also observed a significant association of $470 \mathrm{M}$ with the T9 no mutation IB chromosomes. Molecular studies are necessary to elucidate the basis of the pathogenesis.

Two opposing hypotheses could be proposed to explain the role of T9 in the aetiology of IB. T9 could be a predisposing genotype that does not lead to disease on its own, but leads to IB when in association with defects in an as yet unidentified gene. Alternatively, T9 could be an attenuator for CF instead of a mutation with a role in the aetiopathogenesis of IB. A higher CFTR activity conferred by T9 (more so in association in cis with 470M) could dampen the effect of an in cis mutation and manifest a milder form of CF. This fits in well with the model that mild CFTR mutations lead to milder forms of disease, such as disseminated bronchiectasis and obstructive azoospermia. ${ }^{38}$ As for the no mutation patients, T9 would be expected to compensate for defects in the hypothetical gene. The hypothetical gene would be expected to exert its effect in an autosomal recessive fashion, and the frequency of its defective form in the population would be lower than CF mutations. IB associated with this gene would thereby be noticeable only in populations with high consanguinity, similar to the Turkish population.

The attenuator hypothesis would explain why 12 of the patients developed a more CF-like disease several years after IB diagnosis. One such patient had mutations on both CFTR chromosomes $(-33 \mathrm{G}>\mathrm{A} / \mathrm{CFTR}$ dele2,3). He had the lower left lobe removed at the age of 4 and was referred to our clinic at the age of 5 with borderline sweat test values of 52 and 50 $\mathrm{mEq} / \mathrm{l}$. Eighteen and 20 months later the values were high $(64$ and $63 \mathrm{mEq} / \mathrm{l}$, respectively), and he had developed CF-like gastrointestinal problems. The remaining five patients with two mutations had normal sweat test values $(<40 \mathrm{mEq} / \mathrm{l})$ and no gastrointestinal complaints at the ages of $7,11,13,13$, and 14. It will be interesting to follow whether these patients also develop CF-like clinical findings in the future.

Identification of an IB modifier gene would be of much clinical value, as no gene other than CFTR has been implicated in the aetiology of this common disease. A modifier gene has already been identified for idiopathic chronic pancreatitis associated with CFTR mutations. ${ }^{39}$ The four IB sib pairs and their six unaffected sibs would give sufficient genetic information in a genome scan study aiming at the identification of the locus for the hypothetical gene. Identification of the gene would also increase our knowledge on the pathogenesis of CFTR defects and shed light on other diseases associated with CFTR.

\section{ACKNOWLEDGEMENTS}

The work was supported by the Scientific and Technical Research Council of Turkey (SBAG-191T070), Bođaziçi University Research Fund (98B105), and the Turkish Academy of Sciences.

\section{Authors' affiliations}

V N Ninis, M O Kýlýnç*, A Tolun, Department of Molecular Biology and Genetics, Boðaziçi University, Istanbul, Turkey

M Kandemir, E Daðlý, Department of Paediatrics, Marmara University Hospital, Istanbul, Turkey

Correspondence to: Dr A Tolun, Department of Molecular Biology and Genetics, Boðaziçi University, Bebek, Istanbul 34342, Turkey; tolun@boun.edu.tr

*Present address: School of Medicine, University of Louisville, Kentucky, USA

\section{REFERENCES}

1 Pignatti PF, Bombieri C, Benetazzo M, Casartelli A, Trabetti E, Gile LS, Martinati LC, Boner AL, Luisetti M. CFTR gene variant IVS8-T5 in disseminated brochiectasis. Am J Hum Genet 1996:58:889-92.

2 Girodon E, Cazeneuve C, Lebargy F, Chinet T, Costes B, Ghanem N Martin J, Lemay S, Scheid P, Housset B, Bignon J, Goossens M. CFTR gene mutations in adults with disseminated bronchiectasis. Eur J Hum Genet 1997;5: 149-55.

3 Friedman KJ, Heim RA, Knowles MR, Silverman LM. Rapid characterization of the variable length polythymidine tract in the cystic fibrosis (CFTR) gene: association of the T5 allele with selected CFTR mutations and its incidence in atypical sinopulmonary disease. Hum Mutat 1997; 10:108-15

4 Bombieri C, Benetazzo M, Saccomani A, Belpinati F, Gile LC, Luisetti $M$, Pignatti PF. Complete mutational screening of the CFTR gene in 120 patients with pulmonary disease. Hum Genet 1998;103:718-22.

5 Tzetis M, Efthymiadou A, Strofalis S, Psychou P, Dimakou A, Pouliou E, Doudounakis S, Kanavakis E. CFTR gene mutations - including three novel nucleotide substitutions - and haplotype background in patients with asthma, disseminated bronchiectasis and chronic obstructive pulmonary disease. Hum Genet 2001;108:216-21

6 Castellani C, Quinzii C, Altieri S, Mastella G, Assael BM. A pilot survey of cystic fibrosis clinical manifestations in CFTR mutation heterozygotes. Genet Test 2001:5:249-54.

7 Schroeder SA, Gaughan DM, Swift M. Protection against asthma by CFTR $\triangle F 508$ mutation: a heterozygote advantage in cystic fibrosis. Nat Med 1995; 1:703-5.

8 Culard JF, Desgeorges M, Costa P, Laussel M, Razakatzara G, Navratil $\mathrm{H}$, Demaille J, Claustres M. Analysis of the whole CFTR coding regions and splice junctions in azoospermic men with congenital bilateral aplasia of epididymis or vas deferens. Hum Genet 1994;93:467-70.

9 Chillon M, Casals T, Mercier B, Bassas L, Lissens W, Silber S, Romey MC, Ruiz-Romero J, Verlingue C, Claustres M, Nunes V, Ferec C, Estivill $\mathrm{X}$. Mutations in the cystic fibrosis gene in patients with congenital absence of the vas deferens. N Engl J Med 1995:332:1475-80.

10 Costes B, Girodon E, Ghanem N, Flori E, Jardin A, Soufir JC, Goossens $M$. Frequent occurrence of the CFTR intron $8(T G)_{m} 5 T$ allele in men with congenital bilateral absence of the vas deferens. Eur J Hum Genet 1995; 3:285-93.

11 Mercier B, Verlingue C, Lissens W, Silber SJ, Novelli G, Bonduelle M, Audrezet MP, Ferec $C$. Is congenital bilateral absence of vas deferens a primary form of cystic fibrosis? Analysis of the CFTR gene in 67 patients. Am J Hum Genet 1995;56:272-7.

12 Miller PW, Hamosh A, Macek Jr M, Greenberger PA, MacLean J, Walden SM, Slavin RG, Cutting GR. Cystic fibrosis transmembrane conductance regulator (CFTR) gene mutation in patients with allergic bronchopulmonary aspergillosis. Am J Hum Genet 1996;59:45-51.

13 Sharer N, Schwarz M, Malone G, Howarth A, Painter J, Super M, Braganza J. Mutations of the cystic fibrosis gene in patients with chronic pancreatitis. N Engl J Med 1998;339:645-52

14 Cohn JA, Friedman KJ, Noone PG, Knowles MR, Silverman LM, Jowell PS. Relation between mutations of the cystic fibrosis gene and idiopathic pancreatitis. N Engl J Med 1998;339:653-8.

15 Kýlýnç MO, Ninis VN, Daðlý E, Mübeccel D, Özkýnay F, Arýkan Z, Çoðulu Ö, Hüner G, Karakoç F, Tolun A. Highest heterogeneity for cystic fibrosis: 36 mutations account for $75 \%$ of all CF chromosomes in Turkish patients. Am J Med Genet 2002; 113:250-7

16 Fanen P, Ghanem N, Vidaud M, Besmond C, Martin J, Costes B, Plassa F, Goossens M. Molecular characterization of cystic fibrosis: 16 novel mutations identified by analysis of the whole cystic fibrosis conductance 
transmembrane regulator (CFTR) coding regions and splice site junctions. Genomics 1992;13:770-6.

17 Costes B, Fanen P, Goossens M, Ghanem N. A rapid, efficient, and sensitive method for simultaneous detection of multiple cystic fibrosis mutations. Hum Mutat 1993:2:185-91.

18 Highsmith WE, Burch LH, Zhou Z, Olsen JC, Boat TE, Spock A, Gorvoy JD, Quittell L, Friedman KJ, Silverman LM, Boucher RC, Knowles MR. A novel mutation in cystic fibrosis patients with pulmonary disease but normal sweat chloride concentrations. N Engl J Med 1994;331:974-80.

19 Chillon M, Dörk T, Casals T, Gimenez J, Fonknechten N, Will K, Ramos $D$, Nunes V, Estivill X. A novel donor splice site in intron 11 of the CFTR gene, created by mutation $1811+1.6 \mathrm{~kb} A \rightarrow G$ produces a new exon: high frequency in Spanish cystic fibrosis chromosomes and association with severe phenotype. Am J Hum Genet 1995:56:623-9.

20 Dörk T, Macek Jr M, Mekus F, Tümmler B, Tzountaris J, Casals T, Krebsova A, Koudova M, Sakmaryova I, Macek Sr M, Vavrova V Zemkova D, Ginter E, Petrova NV, Ivachenko T, Baranov V, Witt $M$, Pogorzelski A, Bal J, Zekanowsky C, Wagner K, Stuhrmann M, Baver I, Seydewitz HH, Neumann T, Jakubitzka S, Kraus C, Thamm B Nechiporenko M, Livshits L, Mosse N, Tsukerman G, Kadasi L, Ravnic-Glavac M, Glavac D, Komel R, Vouk K, Kucinkas V, Krumina A, Teder M, Kocheva S, Efremov GD, Onay T, Kýrdar B, Malone G, Schwarz M, Zhou Z, Friedman KJ, Carles S, Claustres M, Bozon D, Verlingue $C$, Ferec $C$, Tzetis $M$, Kanavakis E, Cuppens H, Bombieri C, Pignatti PF, Sangiulo F, Jordanova A, Kusic J, Radockovic B, Sertic J, Richter D, Stavljenic Rukavina A, Bjorck E, Strandvic B, Cardoso H, Mongomery M, Nakielma B, Hughes D, Estivill X, Aznarez I, Tullis E, Tsui LC, Zielenski J. Characterization of a novel $21-\mathrm{kb}$ deletion,

CFTRdele2,3(21 kb), in the CFTR gene: a cystic fibrosis mutation of Slavic origin common in Central and East Europe. Hum Genet 2000; 106:259-68

21 Costes B, Girodon E, Vidaud D, Flori E, Jardin A, Ardalan A, Contaville $P$, Fanen $P$, Niel E, Vidaud M, Goossens M. Prenatal detection by real-time PCR and characterization of a new CFTR deletion, 3600+15kbdel5.3kb (or CFTRdele 19). Clin Chem 2000:46:1417-20.

22 Romey MC, Guittard C, Carles S, Demaille J, Claustres M. First putative sequence alterations in the minimal CFTR promoter region. J Med Genet 1999;36:263-4

23 Kerem BS, Zielenski J, Markiewicz D, Bozon D, Gazit E, Yahaf J, Kennedy D, Riordan J, Collins F, Rommens JM, Tsui LC. Identification of mutations in regions corresponding to the 2 putative nucleotide (ATP)-binding folds of the cystic fibrosis gene. Proc Natl Acad Sci USA 1990;87:8447-51

24 Chehab FF, Johnson J, Lovie E, Goossens M, Kawasaki E, Erlich H. A dimorphic 4-bp repeat in the cystic fibrosis gene is in absolute linkage disequilibrium with the $\Delta \mathrm{F} 508$ mutation: implications for prenatal diagnosis and mutation origin. Am J Hum Genet 1991;48:223-6.

25 Morral N, Nunes V, Casals T, Estivill X. CA/GT microsatellite alleles within the cystic fibrosis tranmembrane conductance regulator (CFTR) gene are not generated by unequal crossingover. Genomics 1991;10:692-8.

26 Zielenski J, Markiewicz D, Rinisland F, Rommens J. A cluster of highly polymorphic dinucleotide repeats in intron $17 \mathrm{~b}$ of the cystic fibrosis transmembrane conductance regulator (CFTR) gene. Am J Hum Genet 1991:49:1256-62.

27 Sokal RR, Rohlf FJ. Biometry. New York: Freeman, 1995:736.

28 Tucker SJ, Tannahill D, Higgins CF. Identification and developmental expression of the Xenopus laevis cystic fibrosis transmembrane conductance regulator gene. Hum Mol Genet 1992;1:77-82.
29 Mercier B, Lissens W, Novelli G, Kaladjieva L, De Arce M, Kapranov N Canki Klain N, Lenoir G, Chauveau P, Lenaerts C, Rault G, Cashman S, Sangiuolo F, Audrezet MP, Dallapicola B, Guillermit H, Bonduelle M, Liebaers I, Quere I, Verlingue C, Ferec C. Identification of eight novel mutations in a collaborative analysis of a part of the second transmembrane domain of the CFTR gene. Genomics 1993:16:297-7.

30 Pignatti PF, Bombieri C, Marigo C, Benetazzo M, Luisetti M. Increased incidence of cystic fibrosis gene mutations in adults with disseminated bronchiectasis. Hum Mol Genet 1995; 4:635-9.

31 Bombieri C, Giorgi S, Carles $S$, de Cid R, Belpinati F, Tandoi C Pallares-Ruiz N, Lazaro C, Ciminelli BM, Romey MC, Casals T, Pompei F, Gandini G, Claustres M, Estivill X, Pignatti PF, Modiano G. A new approach for identifying non-pathogenic mutations. An analysis of the cystic fibrosis transmembrane regulator gene in normal individuals. Hum Genet 2000;106:172-8.

32 Osborne L, Santis G, Schwarz M, Klinger K, Mclntosh I, Schwartz M, Nunes V, Macek M Jr, Reiss J, Highsmith WE Jr, McMahon R, Novelli G Malik N, Bürger J, Anvret M, Wallace A, Williams C, Mathew C, Rozen R, Graham C, Gasparini P, Bal J, Cassiman JJ, Balassopoulou A Davidow L, Raskin S, Kalaydjieva L, Kerem B, Richards S, Simon-Bouy B, Super M, Wulbrand U, Keston M, Estivill X, Vavrova V, Friedman KJ, Barton D, Dallapicola B, Stuhrmann M, Beards F, Hill AJM, Pignatti PF, Cuppens $H$, Angelicheva D, Tümmler B, Brock DJH, Casals T, Macek M, Schmidtke J, Magee AC, Bonizatto A, De Boeck C, Kuffardjieva A, Hodson M and Knight RA. Incidence and expression of the N13003K mutation of the cystic fibrosis (CFTR) gene. Hum Genet 1992;89:653-8.

33 Beck S, Penque D, Garcia S, Gomes A, Farinha C, Mata L, Gulbekian S, Gil-Ferreia K, Duarte A, Pacheco P, Barreto C, Lopes B, Cavaco J, Lavinha J, Amaral MD. Cystic fibrosis patients with the $3272-26 A \rightarrow G$ mutation have mild disease, leaky alternative mRNA splicing, and CFTR protein at the cell membrane. Hum Mutat 1999:14:133-44.

34 Amaral MD, Pacheco P, Beck S, Farinha CM, Penque D, Noguiera P, Barreto Lopes B, Casals T, Dapena J, Gartner S, Vasquez C, Perez-Friaz , Olveira C, Cabanas R, Estivill X, Tzetis M, Kanavakis E, Doudounakis S, Dörk T, Tümmler B, Girodon-Boulandet E, Cazeneuve C, Goossens M, Blayau $M$, Claudine Verlingue, Vieira I, Ferec $C$, Claustres $M$, Desgeorges $M$, Clavel C, Birembaut $P$, Hubert D, Bienvenu T, Adoun $M$, Chomel J-C, De Boeck K, Cuppens H, Lavinha J. Cystic fibrosis patients with the $3272-26 \mathrm{~A} \rightarrow \mathrm{G}$ splicing mutation have milder disease than F508del homozygotes: a large European study. J Med Genet $2001 ; 38: 777-82$

35 Andrieux J, Audrézet MP, Frachon I, Leroyer C, Roge C, Scotet V, Férec C. Quantification of CFTR splice variants in adults with disseminated bronchiectasis, using the TaqMan fluorogenic detection system. Clin Genet 2002:62:60-7

36 Cuppens $\mathbf{H}$, Lin $W$, Jaspers $M$, Costes $B$, Teng $H$, Vankeerberghen $A$, Jorsen M, Droogmans G, Reynaert I, Goossens M, Nilius B, Cassiman JJ. Polyvariant mutant cystic fibrosis transmembrane conductance regulator gene: the polymorphic (TG) locus explains the partial penetrance of the T5 polymorphism as a disease mutation. I Clin Invest 1998:101:487-96.

37 Noone PG, Pue CA, Zhou Z, Friedman KJ, Wakeling EL, Ganeshananthan M, Simon RH, Silverman LM, Knowles MR. Lung disease associated with the IVS8 5T allele of the CFTR gene. Am J Respir Crit Care Med 2000;162:1919-24.

38 Estivill X. Complexity in a monogenic disease. Nat Genet $1996 ; 12: 348-50$

39 Cohn JA, Noone PG, Jowell PS. Idiopathic pancreatitis related to CF: complex inheritance and identification of a modifier gene. J Invest Med 2002;50:247-55S.

\title{
FMRP expression studies in blood and hair roots in a fragile $X$ family with methylation mosaics
}

\author{
B B A de Vries, L-A Severijnen, A Jacobs, R Olmer, D J J Halley, B A Oostra, \\ R Willemsen
}

$\mathrm{T}$ he fragile $\mathrm{X}$ syndrome is a common cause of familial mental retardation with an estimated prevalence of $1 / 4000-1 / 6000$ for males in western countries. ${ }^{1-3}$ This $X$ linked disorder is characterised by mental retardation with additional features like a long face with large protruding ears, macro-orchidism, and eye gaze avoidance. ${ }^{4-6}$ The causative mutation is an amplification of a trinucleotide (CGG) repeat in the $5^{\prime}$ UTR of the FMRI gene. Normal people have between six and 54 CGG repeats, carriers of the premutation have between
55 and 200, and affected subjects have more than 200 CGG repeats in their FMRI gene, the so called full mutation. ${ }^{78}$ The latter expansion is accompanied by hypermethylation of the repeat and its upstream region resulting in a shutdown of transcription and absence of the FMRP. ${ }^{9-11}$

In fragile $X$ patients, two special subclasses of mosaicism can be distinguished on the basis of size and methylation pattern: (1) subjects with a premutation in a proportion of their cells in addition to a full mutation, often referred to as "size 


\section{Key points}

- In fragile X patients two special subclasses of mosaicism can be distinguished on the basis of size and/or methylation pattern: patients with full mutation and premutation, called "size mosaics", and patients with intercellular variations of the methylation status, called "methylation mosaics".

- Within a known fragile X family, three brothers with methylation mosaic patterns were studied using the FMRP antibody test on both blood smears and hair roots. The index patient aged 10 years (case 1) was diagnosed at the age of 5 years; he was mildly retarded and had some clinical fragile $X$ features. DNA analysis showed a full mutation (200-250 repeats) with $86 \%$ unmethylated mutations. His 5 year old brother (case 2) had a mutation of 177 repeats that was unmethylated in $67 \%$ of cells. His (early) development was considered normal and he lacked additional fragile $X$ features. The third brother (case 3) had a mutation of 183-187 repeats that was unmethylated in $86 \%$ of cells. His development was normal at the age of 3 years and he did not have any significant fragile $X$ features.

- In cases 1, 2, and 3, FMRP expression in blood (in duplicate) was $20 \%$ and $10 \%, 22 \%$ and $10 \%$, and $7 \%$ and $2 \%$, respectively, and $67 \%, 85 \%$ and $88 \%$ of their hair roots expressed FMRP.

- These results suggest that FMRP expression in hair roots gives a better reflection of the mental development than FMRP expression in leucocytes, which is consistent with the common embryonic origin of hair roots and neuronal cells.

mosaics"; this pattern can be observed in $20-40 \%$ of male patients ${ }^{12}{ }^{13} ;(2)$ subjects with intercellular variations in the methylation status of a full mutation, "methylation mosaics". ${ }^{14}$ In a large multicentre study, "methylation mosaicism" was observed in $3 \%$ of the males with a full mutation. ${ }^{12}$

In 1995, Willemsen et a ${ }^{15}$ developed an FMRP antibody test for detecting the presence or absence of FMRP in lymphocytes and later in hair roots. ${ }^{16}$ This test allowed for screening for the fragile $X$ syndrome among mentally retarded males ${ }^{17}$ and in addition made quantification of the number of FMRP expressing cells in patients possible. Using this technique in blood smears, Tassone et $a l^{18}$ were able to find correlations between FMRP expression and IQ in males with size mosaicism and methylation mosaicism. Very recently, a highly significant correlation has been found between FMRP expression in hair roots and cognitive functioning in females carrying a full mutation ( $\mathrm{R}$ Willemsen, in press).

Here, a study of FMRP expression in blood and hair roots is reported in three male sibs with a varying degree of methylation mosaicism.

\section{PATIENTS AND METHODS}

The three brothers who are the subjects of this report are from a fragile X family known to the Department of Clinical Genetics, Rotterdam. The family was ascertained through a son of the mother's sister who had the classical clinical presentation of the fragile X syndrome confirmed by a fully methylated full mutation of the FMRI gene.

\section{DNA analysis}

Genomic DNA was isolated ${ }^{19}$ from blood leucocytes digested with HindIII and the methylation sensitive enzyme EagI and hybridised with probe pP2 according to standard protocols. ${ }^{20}$
Sizing of the Southern blot and densitometry were done using a Kodak Electrophoresis Documentation and Analysis System 120.

\section{Protein analysis}

Blood smears were made from one drop of blood within two hours after collection. Slides were air dried. Hairs were plucked from different locations on the scalp and analysed within 24 hours. The FMRP was visualised by using monoclonal antibodies lAl against FMRP. ${ }^{21}$ Further immunoincubations were performed according to procedures described previously ${ }^{15} 22$ (http://www.eur.nl/FGG/CHl/frax/). A total of 100 leucocytes were analysed per patient and scoring for FMRP expression was performed by two people independently.

\section{Determination of IQ levels}

The Wechsler Intelligence Scale for Children-Revised (WISCR), the McCarthy Scales of Children's Abilities (MSCA), the Wechsler Preschool and Primary Scale of Intelligence (WIPPSI-R), and the Peabody Picture Vocabulary Test-Revised (PPVT-R) were used to test the intellectual abilities by one examiner (AJ) who was not informed about the genetic status of the children tested. The WISC-R is suitable for children from the age of 6 years whereas the MSCA, the WIPPSI-R, and PPVT-R should be used for younger children. The verbal, performance, and full scale IQ scores were calculated.

\section{RESULTS}

\section{Case reports}

Case 1

This boy was born after a normal pregnancy and delivery with a birth weight of $3250 \mathrm{~g}$. In his first year of life he had frequent ENT related problems which disappeared after tonsillectomy and the insertion of grommets. His early development was somewhat slow but within the normal range: he sat at 8 months, walked unaided at 18 months, and spoke his first words at 1 year. At the age of 2 years hyperactive behaviour was noted which disappeared at 4 years of age. However, at that age he appeared to be unable to attend normal school. For further evaluation he was referred to our centre and because of the family history (the mother's sister had two sons with the fragile X syndrome) DNA analysis of the FMRl gene was performed.

At the age of 5 years he had normal physical measurements, height $1.17 \mathrm{~m}$ (70th centile) and head circumference $52.5 \mathrm{~cm}$ (75th centile). He had a long, narrow face with a normal chin, normally shaped and sized ears, periorbital fullness, and normal teeth (fig 1). His testes were mildly enlarged for his age (4 $\mathrm{ml} / 4 \mathrm{ml}$ ). He had hyperextensible finger joints and relatively broad and short halluces. His behaviour was normal with normal eye contact.

Psychological testing at the age of 10 years, using the WISC-R, showed a full scale IQ score of 55 with a verbal IQ score of 56 and a performance IQ score of 61 .

\section{Case 2}

This boy is the 4 year younger brother of case 1 . He was also born after an uneventful pregnancy and delivery with a normal birth weight. His early development was normal: he sat at 9 months, stood at 10 months, and walked unaided at 14 months. Because of the diagnosis in his older brother, he was tested for the fragile $X$ syndrome at the age of 1 year 3 months.

At the age of 5 years he had normal physical measurements, height $110 \mathrm{~m}$ (25th centile) and head circumference $51.8 \mathrm{~cm}$ (60th centile). He had a normal face, except for a broad forehead which was observed in the father as well, some periorbital fullness, and normal ears (fig 1). His genitals were normal. His behaviour was normal with normal eye contact. 

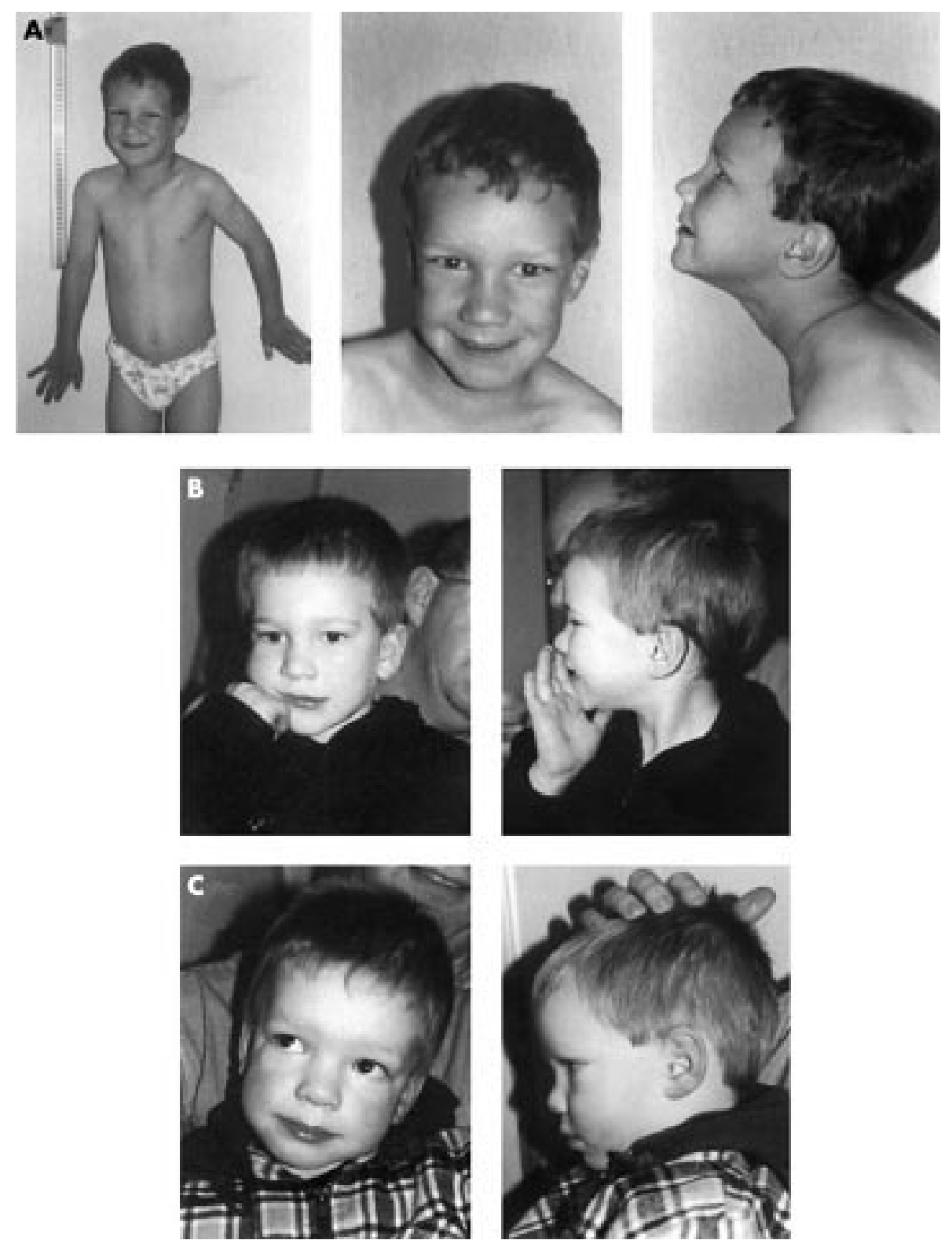

Figure 1 (A) Case 1 at the age of 5 years, (B) case 2 at the age of 5 years, and (C) case 3 at the age of 3 years.

Psychological testing at the age of 5 years showed a full scale IQ score of 81 with the MSCA and 75 with the WIPPSI-R.

\section{Case 3}

This boy is the 6 years younger brother of case 1. He was born after a normal pregnancy and delivery with a birth weight of $3750 \mathrm{~g}$. His development was normal: he walked at 14 months and spoke normal sentences at 3 years.

At the age of 3 years he had normal physical measurements, height $1.00 \mathrm{~m}$ (50th centile) and head circumference $51.5 \mathrm{~cm}$ (70th centile). He had no dysmorphic facial features, except for a broad forehead which was observed in the father as well; he had normal sized and shaped ears. His genitals were normal. He had some hyperextensibilty of MCP V. His behaviour was normal with normal eye contact. Psychological testing at the age of 3 years 8 months showed a full scale IQ score of 91 with the MSCA and 97 with the PPVT-R.

\section{Molecular findings}

In case 1, a full mutation was found in his leucocytes using Southern blot analysis: a 14\% methylated 560 bp larger than normal band ( $\sim 217$ repeats) and a $86 \%$ unmethylated $670 \mathrm{bp}$ larger than normal band ( 253 repeats) (fig 2 ).

Protein analysis in blood smears (in duplicate) showed $10 \%$ and $20 \%$ of the leucocytes and $67 \%$ of the hair roots (10/15) expressing FMRP.

In case 2 , a mutation that was smaller than in case 1 was found in leucocytes using Southern blot analysis: a 33\% methylated $440 \mathrm{bp}$ larger than normal band ( $\sim 177$ repeats) and a $67 \%$ unmethylated $440 \mathrm{bp}$ larger than normal band ( $\sim 177$ repeats $)$.

Protein analysis in blood smears (in duplicate) showed $10 \%$ and $22 \%$ of the leucocytes and $85 \%$ of the hair roots $(17 / 20)$ expressing FMRP.

In case 3, a mutation similar in size to that of case 2 was also found in leucocytes using Southern blot analysis: a 14\% methylated 470 bp larger than normal band ( 187 repeats) and an $86 \%$ unmethylated 460 bp larger than normal band ( $\sim 183$ repeats) (fig 2 ).

Protein analysis in blood smears (in duplicate) showed 2\% and $7 \%$ of the leucocytes and $88 \%$ of the hair roots $(23 / 26)$ expressing FMRP. 


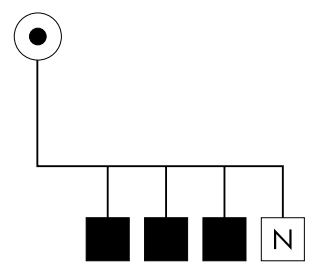

Figure 2 Analysis with probe pP2 of Hindlll/Eagl digested DNA (leucocytes) of the mother, cases 1, 2, and 3, and a normal sib.

123

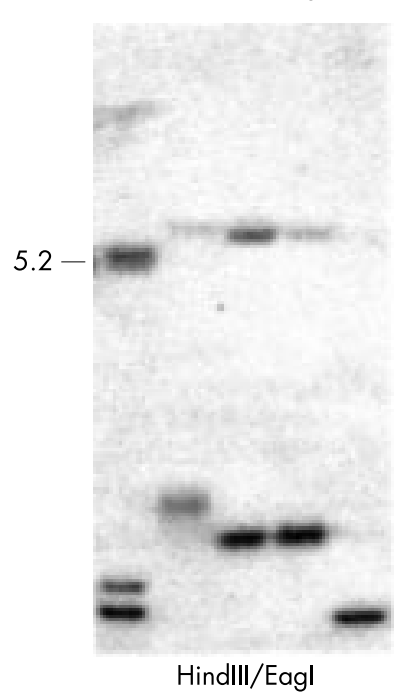

Table 1 Summary test results in the three brothers

\begin{tabular}{lllll}
\hline & & $\begin{array}{l}\text { FMR1 \% } \\
\text { unmethylated }\end{array}$ & FMRP & \\
\cline { 4 - 5 } & blood & $\begin{array}{l}\text { Lymphocytes } \\
\text { (in duplicate) }\end{array}$ & Hair roots \\
\hline Case 1 & 55 & $86 \%$ & 10 and 20\% & $67 \%$ \\
Case 2 & 75 and 81 & $67 \%$ & 10 and 22\% & $85 \%$ \\
Case 3 & 91 and 97 & $86 \%$ & 2 and 7\% & $88 \%$ \\
\hline
\end{tabular}

The test results are summarised in table 1.

\section{DISCUSSION}

According to the definition of mosaicism, all fragile $\mathrm{X}$ males are mosaic as they have different amplified repeat sequences in the FMRI gene in different cells. However, two special subclasses can be distinguished; $20-40 \%$ of fragile X males have a premutation in a proportion of cells and the full mutation in the remaining (majority) of cells. In general, the proportion of cells with a premutation is lower than $<30 \%$ and various studies have shown that the cognitive functioning of these fragile $X$ patients is not significantly better than the males with a full mutation, suggesting that the number of FMRP expressing cells with a premutation is insufficient. ${ }^{12}{ }^{23}$ However, high functioning males with a size mosaic pattern have been described ${ }^{24-26}$ and Tassone et al ${ }^{18}$ detected a correlation between FMRP expression in blood smears and IQ in mosaic males.

For the second group of mosaic patients, the so called "methylation mosaics" the situation is different. These patients have a full mutation in all cells but in a proportion of cells the full mutation is unmethylated. The cells with an unmethylated full mutation are able to produce FMRP and can therefore function normally. Depending on their proportion, they are able to compensate for the loss of functioning of the cells with a methylated full mutation. Various reports on patients with methylation mosaicism suggest that a proportion of cells with an unmethylated full mutation of at least $40 \%$ of normal is likely to be required for normal cognitive functioning. ${ }^{24}{ }^{27-36}$ This is supported by actual FMRP studies in blood smears of patients with methylation mosaicism that showed that all mosaic patients with a normal IQ had FMRP in $\geqslant 50 \%$ of lymphocytes. ${ }^{18}{ }^{32}$ This situation is reminiscent of the situation in females with a full mutation where cognitive function is related to the $\mathrm{X}$ inactivation pattern. ${ }^{12} 14$ 37-39

FMRP expression studies in blood smears of methylation mosaic males have been reported. Smeets et al ${ }^{31}$ reported normal protein expression in cell lines of two normal functioning adults with an unmethylated full mutation. De Vries et $a l^{32}$ reported three cousins with $75 \%, 40 \%$, and $10 \%$ cells expressing FMRP who had an unmethylated full mutation in 90\%, $35 \%$, and $10 \%$ of the cells, respectively. The latter two were both retarded whereas the adult males with $75 \%$ FMRP expressing cells had a normal IQ. Tassone et al ${ }^{18}$ found a correlation between IQ and FMRP expression in blood smears in 13 males with a partially methylated full mutation. They also found three non-retarded mosaic males with expression of FMRP in $\geqslant 50 \%$ of lymphocytes. ${ }^{18}$ The findings of normal FMRP expression in partially unmethylated full mutations were in contrast with the report of Feng et al, ${ }^{40}$ who found markedly diminished FMRP production in fibroblast clones from transcripts with more than 200 repeats. These conflicting findings raise the question of whether unmethylated full mutations have normal or diminished FMRP expression, what is the relation to cognitive functioning, and what is the correct tissue to study. Interestingly, Tassone et a ${ }^{41}$ reported a six-fold increase of FMRI mRNA levels in methylation mosaic males suggesting the existence of a compensatory response to impeded FMRP production.

In the oldest of the three reported brothers, the size of the (un)methylated alleles are all in the full mutation range whereas the other two brothers have (un)methylated alleles in the high premutation range; thus the latter two do have partially methylated premutation sized alleles which is quite rare.

The proportion of cells expressing FMRP in a blood smear ascertained by the FMRP antibody test did not correspond very well with the proportion of unmethylated FMRI alleles (pre- or full mutation sized) as ascertained by DNA blotting analysis. It suggests that in leucocytes the translation might also be hampered in the large unmethylated premutation sized alleles. It also shows that accurate prediction of mental functioning in males with an intercellular variation of the methylation status through FMRP studies in blood smears is, like DNA analysis, less valid. However, FMRP expression in hair roots did reflect the cognitive functioning in the three brothers. Both brothers with normal IQs (81 and 91) had a high proportion of FMRP expressing hair roots $(85 \%$ and $90 \%$, respectively). This is consistent with the common embryonic origin, ectoderm, of hair roots and neuronal cells whereas blood is of mesodermal origin. Of course a larger number of males with (un)methylated full mutations need to be tested to assess the validity of the relationship between FMRP expression in hair roots and mental functioning.

\section{ACKNOWLEDGEMENTS}

We thank the patients and their family for their kind support.

\section{.................}

Authors' affiliations

B B A de Vries, A Jacobs, Department of Human Genetics, University Medical Centre Niimegen, The Netherlands

L-A Severiinen, R Olmer, D J J Halley, B A Oostra, R Willemsen, Department of Clinical Genetics, Erasmus University Rotterdam, The

Netherlands

Correspondence to: Dr B B A de Vries, Department of Clinical Genetics, 
University Medical Centre Niimegen, P O Box 9101, $6500 \mathrm{HB}$

Nijmegen, The Netherlands; b.devries@antrg.umcn.nl

\section{REFERENCES}

1 Turner G, Webb T, Wake S, Robinson H. Prevalence of fragile X syndrome. Am J Med Genet 1996;64:196-7

2 Murray A, Youings S, Dennis N, Latsky L, Linehan P, McKechnie N Macpherson J, Pound $M$, Jacobs P. Population screening at the FRAXA and FRAXE loci: molecular analyses of boys with learning difficulties and their mothers. Hum Mol Genet 1996:5:727-35

3 De Vries BB, van den Ouweland AM, Mohkamsing S, Duivenvoorden HJ, Mol E, Gelsema K, van Rijn M, Halley DJ, Sandkuijl LA, Oostra BA, Tibben A, Niermeijer MF. Screening and diagnosis for the fragile $X$ syndrome among the mentally retarded: an epidemiological and psychological survey. Collaborative Fragile X Study Group. Am J Hum Genet 1997;61:660-7

4 Fryns JP. X-linked mental retardation and the fragile $X$ syndrome: a clinical approach. In: Davies KE, ed. The fragile X syndrome. Oxford: Oxford University Press, 1989:1-39.

5 Hagerman RJ. Physical and behavioural phenotype. In: Hagerman RJ, Cronister A, eds. Fragile-X syndrome: diagnosis, treatment and research Baltimore: The Johns Hopkins University Press, 1996:3-87.

6 De Vries BBA, Halley DJJ, Oostra BA, Niermeijer MF. The fragile X syndrome. J Med Genet 1998:35:579-89.

7 Verkerk AJ, Pieretti M, Sutcliffe JS, Fu YH, Kuhl DP, Pizzuti A, Reiner O, Richards S, Victoria MF, Zhang FP, Eussen BE, van Ommen GJB, Blonden LAJ, Riggins GJ, Chastain JL, Kunst CB, Galjaard H, Caskey CT, Nelson DL, Oostra BA, Warren ST. Identification of a gene (FMR-1) containing a CGG repeat coincident with a breakpoint cluster region exhibiting length variation in fragile $X$ syndrome. Cell 1991;65:905-14.

8 Fu YH, Kuhl DP, Pizzuti A, Pieretti M, Sutcliffe JS, Richards S, Verkerk A, Holden JJ, Fenwick R Jr, Warren ST, Oostra BA, Nelson DL, Caskey CT. Variation of the CGG repeat at the fragile $X$ site results in genetic instability: resolution of the Sherman paradox. Cell 1991;67:1047-58.

9 Pieretti $M$, Zhang FP, Fu YH, Warren ST, Oostra BA, Caskey CT, Nelson $\mathrm{DL}$. Absence of expression of the FMR-1 gene in fragile $X$ syndrome. Cell 1991;66:817-22

10 Sutcliffe JS, Nelson DL, Zhang F, Pieretti M, Caskey CT, Saxe D, Warren ST. DNA methylation represses FMR-1 transcription in fragile $X$ syndrome. Hum Mol Genet 1992;1:397-400.

11 Verheij C, Bakker CE, de Graaff E, Keulemans J, Willemsen R, Verkerk AJ, Galjaard H, Reuser AJ, Hoogeveen AT, Oostra BA. Characterization and localization of the FMR-1 gene product associated with fragile $X$ syndrome. Nature 1993:363:722-4

12 Rousseau F, Heitz D, Tarleton J, MacPherson J, Malmgren H, Dahl N, Barnicoat A, Mathew C, Mornet E, Tejada I, Maddalena A, Spiegel R, Schinzel A, Marcos JAG, Schoderet DF, Schaap T, Maccioni L, Russo S, Jacobs PA, Schwartz C, Mandel JL. A multicenter study on genotype-phenotype correlations in the fragile $\mathrm{X}$ syndrome, using direct diagnosis with probe StB 12.3: the first 2,253 cases. Am J Hum Genet 1994;55:225-37

13 Nolin SL, Glicksman A, Houck G Jr, Brown WT, Dobkin CS. Mosaicism in fragile X affected males. Am J Med Genet 1994:51:509-12.

14 Rousseau F, Heitz D, Biancalana V, Blumenfeld S, Kretz C, Boue J, Tommerup N, Van Der Hagen C, Delozier-Blanchet C, Croquette MF, Gilgenkrantz, S., Jalbert P, Voelckel MA, Oberle I, Mandel JL. Direct diagnosis by DNA analysis of the fragile $X$ syndrome of mental retardation. N Engl J Med 1991:325:1673-81.

15 Willemsen R, Mohkamsing S, de Vries B, Devys D, van den Ouweland A, Mandel JL, Galjaard H, Oostra B. Rapid antibody test for fragile X syndrome. Lancet 1995;345: $1147-8$

16 Willemsen R, Anar B, De Vries BBA, Willems PJ, Galjaard H, Oostra $B A$. Non-invasive screening for the fragile $X$ syndrome using hair root analysis. Am J Hum Genet 1998;63:224.

17 De Vries BBA, Mohkamsing S, Van den Ouweland AMW, Halley DJJ, Niermeijer MF, Oostra BA, Willemsen R. Screening with the FMR 1 protein test among mentally retarded males. Hum Genet 1998; 103:520-2

18 Tassone F, Hagerman RJ, Ikle DN, Dyer PN, Lampe M, Willemsen R, Oostra BA, Taylor AK. FMRP expression as a potential prognostic indicator in fragile X syndrome. Am J Med Genet 1999;84:250-61.

19 Miller S, Dykes D, Polesky H. A simple salting out procedure for extracting DNA from nucleated cells. Nucleic Acids Res 1988;16:1215.

20 Oostra BA, Jacky PB, Brown WT, Rousseau F. Guidelines for the diagnosis of fragile X syndrome. J Med Genet 1993;30:410-13.
21 Devys D, Lutz Y, Rouyer N, Bellocq JP, Mandel JL. The FMR-1 protein is cytoplasmic, most abundant in neurons and appears normal in carriers of a fragile X premutation. Nat Genet 1993;4:335-40.

22 Willemsen R, Anar B, De Diego Otero Y, De Vries BBA, Hilhorst-Hofstee Y, Smits A, Van Looveren E, Willems PJ, Galjaard H, Oostra BA. Noninvasive test for the fragile $X$ syndrome, using hair root analysis. Am I Hum Genet 1999:65:98-103.

23 De Vries BB, Wiegers AM, de Graaff E, Verkerk A, Van Hemel JO, Halley DJ, Fryns JP, Curfs LM, Niermeijer MF, Oostra BA. Mental status and fragile $X$ expression in relation to FMR-1 gene mutation. Eur J Hum Genet 1993; 1:72-9.

24 Hagerman RJ, Hull CE, Safanda JF, Carpenter I, Staley LW, O'Connor RA, Seydel C, Mazzocco MM, Snow K, Thibodeau SN, Kuhl D, Nelson DL, Caskey CT, Taylor A. High functioning fragile X males: demonstration of an unmethylated fully expanded FMR-1 mutation associated with protein expression. Am J Med Genet 1994;51:298-308.

25 Merenstein SA, Sobesky WE, Taylor AK, Riddle JE, Tran HX, Hagerman RI. Molecular-clinical correlations in males with an expanded FMR 1 mutation. Am J Med Genet 1996:64:388-94.

26 Cohen IL, Nolin SL, Sudhalter V, Ding XH, Dobkin CS, Brown WT. Mosaicism for the FMR 1 gene influences adaptive skill development in fragile X-affected males. Am J Med Genet 1996:64:365-9.

27 Loesch DZ, Huggins R, Hay DA, Gedeon AK, Mulley JC, Sutherland GR. Genotype-phenotype relationships in fragile $X$ syndrome: a family study. Am J Hum Genet 1993;53:1064-73.

28 McConkie-Rosell A, Lachiewicz AM, Spiridigliozzi GA, Tarleton J, Schoenwald S, Phelan MC, Goonewardena P, Ding X, Brown WT. Evidence that methylation of the FMR-I locus is responsible for variable phenotypic expression of the fragile X syndrome. Am J Hum Genet 1993;53:800-9.

29 Merenstein SA, Shyu V, Sobesky WE, Staley L, Berry-Kravis E, Nelson $D L$, Lugenbeel KA, Taylor AK, Pennington BF, Hagerman RJ. Fragile X syndrome in a normal IQ male with learning and emotional problems. $J$ Am Acad Child Adolesc Psychiatry 1994;33:1316-21.

30 Rousseau F, Robb LI, Rouillard P. Der Kaloustian VM No mental retardation in a man with $40 \%$ abnormal methylation at the FMR-1 locus and transmission of sperm cell mutations as premutations. Hum Mol Genet 1994;3:927-30.

31 Smeets HJ, Smits AP, Verheij CE, Theelen JP, Willemsen R, van de Burgt I, Hoogeveen AT, Oosterwijk JC, Oostra BA. Normal phenotype in two brothers with a full FMR 1 mutation. Hum Mol Genet 1995;4:2103-8.

32 De Vries BB, Jansen CA, Duits AA, Verheij C, Willemsen R, Van Hemel JO, Van den Ouweland AM, Niermeijer MF, Oostra BA, Halley DJ. Variable FMR 1 gene methylation of large expansions leads to variable phenotype in three males from one fragile X family. J Med Genet 1996;33:1007-10.

33 Lachiewics AM, Spiridigliozzi GA, McConkie-Rosell A, Burgess D, Feng $Y$, Warren ST, Tarleton J. A fragile $X$ male with a broad smear on Southern blot analysis representing 100-500 CGG repeats and no methylation at the Eagl site of the FMRI gene. Am J Med Genet 1996:64:278-82

34 Wang Z, Taylor AK, Bridge JA. FMR 1 fully expanded mutation with minimal methylation in a high functioning fragile X male. J Med Gene 1996;33:376-8

35 Wohrle D, Salat U, Glasser D, Mucke J, Meisel-Stosiek M, Schindler D, Vogel W, Steinbach P. Unusual mutations in high functioning fragile $X$ males: apparent instability of expanded unmethylated CGG repeats. J Med Genet 1998;35:103-11

36 Taylor AK, Tassone F, Dyer PN, Hersch SM, Harris JB, Greenough WT, Hagerman RJ. Tissue heterogeneity of the FMR 1 mutation in a high-functioning male with fragile X syndrome. Am J Med Genet 1999:84:233-9.

37 Taylor AK, Safanda JF, Fall MZ, Quince C, Lang KA, Hull CE, Carpenter I, Staley LW, Hagerman RJ. Molecular predictors of cognitive involvemen in female carriers of fragile $X$ syndrome. JAMA 1994;271:507-14.

38 Reiss AL, Freund LS, Baumgardner TL, Abrams MT, Denckla MB. Contribution of the FMR 1 gene mutation to human intellectual dysfunction. Nat Genet 1995;11:331-4

39 De Vries BB, Wiegers AM, Smits AP, Mohkamsing S, Duivenvoorden HJ, Fryns JP, Curfs LM, Halley DJ, Oostra BA, van den Ouweland AM Niermeijer MF. Mental status of females with an FMR1 gene full mutation. Am J Hum Genet 1996:58:1025-32.

40 Feng Y, Zhang F, Lokey LK, Chastain JL, Lakkis L, Eberhart D, Warren ST. Translational suppression by trinucleotide repeat expansion at FMR 1 Science 1995;268:731-4

41 Tassone F, Hagerman R, Loesch DZ, Lachiewicz A, Taylor AK, Hagerman PJ. Fragile $X$ males with unmethylated, full mutation trinucleotide repeat expansions have elevated levels of FMR 1 messenger RNA. Am J Med Genet 2000;94:232-6. 


\title{
A novel locus for autosomal recessive primary microcephaly (MCPH6) maps to $13 q 12.2$
}

\author{
G F Leal, E Roberts, E O Silva, S M R Costa, D J Hampshire, C G Woods
}

\section{Key points}

- Autosomal recessive primary microcephaly $(\mathrm{MCPH})$ is a genetic disorder in which an affected subject is born with a head circumference $>3$ SD below the expected mean and is mentally retarded.

- We report a novel locus (MCPH6) mapped to chromosome 13q12.2 in a Brazilian family.

- The minimal critical region spans $6 \mathrm{Mb}$ between markers AL139378GT17 and D13S1244 with a maximum two point lod score of 6.25 .

M icrocephaly is the clinical finding of a head circumference measurement greater than three standard deviations (SD) below the population mean for age and sex. It is usually accompanied by mental retardation and there are many diagnoses with both environmental and genetic aetiologies. $^{1}$ Autosomal recessive primary microcephaly (MCPH) (MIM 251200) is a disorder in which affected subjects are born with a small head circumference, explained by a cerebral cortex of reduced size, and are mentally retarded. The brain is structurally normal and, apart from the intellectual impairment, there are no other significant neurological problems, dysmorphic features, or malformations. ${ }^{23}$ In a study carried out in The Netherlands, ${ }^{4}$ the incidence of MCPH was approximately $1 / 250000$ but it is probably greater in populations with a high rate of consanguineous marriages. MCPH has been shown to be genetically heterogeneous with the identification of five loci: MCPHI on 8p23, $\mathrm{MCPH} 2$ on $19 \mathrm{q} 13,{ }^{6} \mathrm{MCPH} 3$ on $9 \mathrm{q} 34,{ }^{7} \mathrm{MCPH} 4$ on $15 \mathrm{ql} 5-\mathrm{q} 21,{ }^{8}$ and MCPH5 on $1 \mathrm{q} 31 .{ }^{9}{ }^{10} \mathrm{MCPH} 1$, 2 , and 3 were mapped in northern Pakistani families, MCPH4 in a Moroccan family, and MCPH5 in northern Pakistani and Turkish families. Here we report the identification by autozygosity mapping ${ }^{11}$ of a novel locus for primary microcephaly, MCPH6, in a north eastern Brazilian family.

\section{MATERIALS AND METHODS \\ Subjects}

The consanguineous family had eight affected subjects (five males and three females, DNA available from seven subjects), with ages varying between 4 and 27 years (fig 1), in four sibships (fig 2). The head circumference of all affected subjects was noted to be small at birth and between 7-10 SD below the expected mean when examined by us. All had mental retardation of moderate severity: the three adults and the adolescent affected were unable to read or write but could speak simple phrases and had basic self-care skills. With the exception of intellectual impairment, there were no other neurological problems (including fits) and motor development had been normal. All eight were in good health and had growth parameters within normal limits. They were not dysmorphic and no syndrome diagnosis could be made. No past medical history or environmental causes could be found to explain the finding of microcephaly. The parents had normal head circumference and intelligence. Ophthalmological examination, standard lymphocyte karyotype (400 bands), and electroencephalogram performed in four affected subjects were normal, and brain scans in two showed no cerebral malformations or neuronal ectopia.

\section{Molecular genetics}

Linkage to the five known MCPH loci was ruled out (data not shown). An autosomal chromosome screen for regions of shared homozygosity was performed on seven of the eight

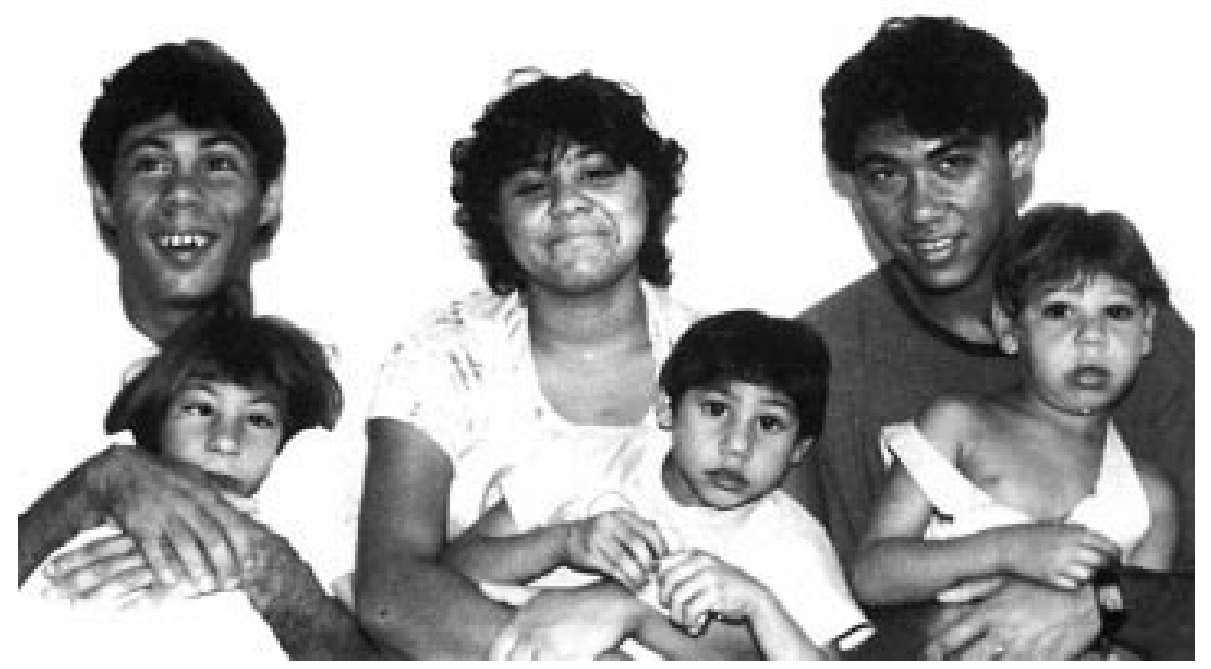

Figure 1 Six of the eight affected subjects with ages between 4 and 27 years with a diagnosis of autosomal recessive primary microcephaly. 


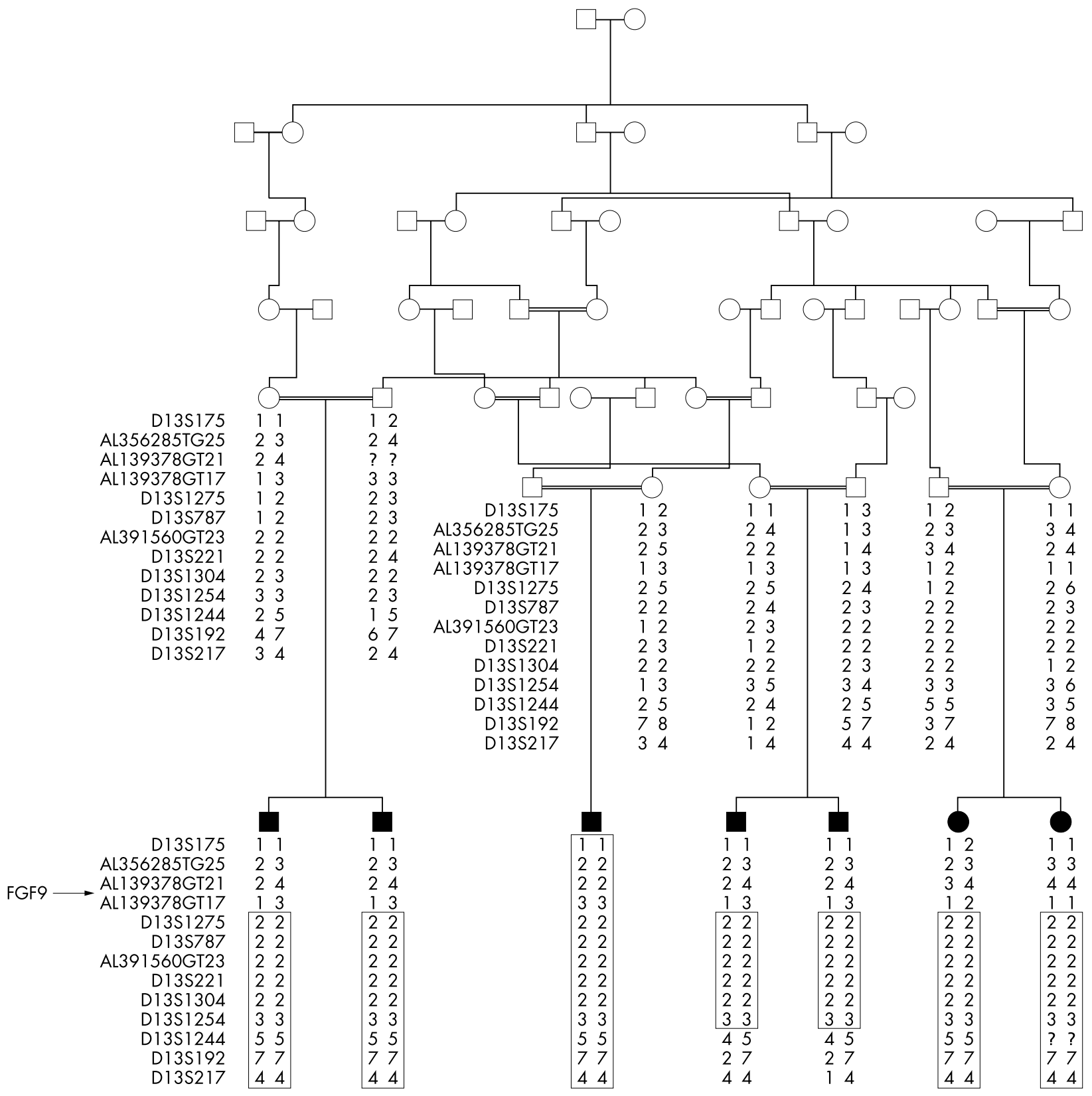

Figure 2 Genotypes for eight markers used in the study at $13 q 12.2$ arranged centromere to qter. Unaffected sibs have been omitted for clarity. Marker order was taken from the Marshfield linkage map. The boxed region shows the shared region of homozygosity in affected subjects. The FGF9 gene, indicated by an arrow, is flanked by markers AL139378GT21 and AL139378GT17 and hence is excluded as a candidate gene from the common homozygous region in affected subjects.

affected subjects and their parents with the CHLC/Weber Human Screening Set version 8 (Research Genetics), which contains 365 autosomal microsatellite repeat markers spaced at approximately $10 \mathrm{cM}$ intervals. PCR amplification of all markers was performed according to the manufacturer's specifications using a Roboseq 4200 (MWG BioTech Ltd). Amplified markers were pooled and electrophoresed on an ABI Prism 377 gene sequencer (Applied Biosystems) on 4.2\% polyacrylamide gels, at $3000 \mathrm{~V}$ and $52^{\circ} \mathrm{C}$, for 2.5 hours. Fragment length analysis was undertaken using the ABI Prism Genescan and Genotyper 1.1.1 analysis packages.

\section{RESULTS}

A single region of homozygosity common to all seven microcephalic subjects was identified on chromosome 13q defined by markers D13S787 and D13S1304. Further refinement of the region was conducted using the following mark- ers selected from the ABI Linkage Mapping Panel Version I (Applied Biosystems), the Todd Panel, ${ }^{12}$ and the Marshfield Linkage Maps: cen - D13S175 - D13S1275 - D13S787 D13S221 - D13S1304 - D13S1254 - D13S1244 - D13S217 D13S120 - D13S171 - D13S1493 - tel. This defined a shared homozygous region on chromosome 13 at band q12.2 with meiotic crossovers between markers D13S175-D13S1275 and D13S1254-D13S1244, with the centromeric and telomeric boundaries of a $9 \mathrm{cM}$ region being defined by D13S175 and D13S1244. Information regarding marker order and relative distances was obtained from the Marshfield Linkage Maps. The marker order obtained from the Marshfield Linkage Maps was in agreement with that derived from analysis of the current draft human genome data.

A fully penetrant autosomal recessive mode of inheritance and a disease gene frequency of 0.003 were assumed. Owing to the complexity of the family structure, equal allele frequencies 
Table 1 Two point lod scores at $\theta=0$ for each marker defining the MCPH6 region at $13 q 12.2$

\begin{tabular}{ll}
\hline Marker & Lod score at $\theta=0$ \\
\hline D13S175 & $-\infty$ \\
D13S1275 & 6.25 \\
D13S787 & 5.90 \\
D13S221 & 3.87 \\
D13S1304 & 2.75 \\
D13S1254 & 4.29 \\
D13S1244 & 2.31
\end{tabular}

were assumed for each marker when calculating the lod scores and the maximum number of alleles was set at 4 . Pedigree allele inconsistencies were identified using PedCheck. ${ }^{13}$ Two point analysis was performed using the LINKAGE analysis programs ${ }^{14}$ at $\theta=0$ for markers in the critical region and results are shown in table 1 with the highest lod score at 6.25 for marker D13S1275.

Novel microsatellite markers to refine the region further were designed using the Human Genome Browser and the Primer3 program, and designated [human BAC accession number][microsatellite repeat unit][number of unit repeats in the reference BAC], for example, AL356285TG25 (fig 2). These allowed us to redefine the centromeric boundary marker as AL139378GT17.

\section{DISCUSSION}

Haplotype and lod score analysis both suggest that the chromosome region 13q12.2, designated the MCPH6 locus, contains a gene which when mutated causes autosomal recessive primary microcephaly.

Within the larger MCPH6 region of $9 \mathrm{cM}$ there is the potential candidate gene, fibroblast growth factor 9 (FGF9). In the nervous system of mice, FGF9 is produced mainly by neurones and may have a role in glial cell growth and differentiation during development. ${ }^{15}{ }^{16}$ The redefinition of the region to $6 \mathrm{cM}$ using novel microsatellite markers flanking FGF9 resulted in the exclusion of this gene (fig 2). We now therefore consider that the gene causing this form of autosomal recessive primary microcephaly must lie within this smaller region of approximately $6 \mathrm{Mb}$. To date, only the MCPHl gene, microcephalin, and the MCPH5 gene, ASPM, have been identified. ${ }^{17}{ }^{18}$ Future identification of the MCPH6 gene may be aided by an insight into how these proteins function and interact within the human brain, such as mitotic spindle activity in the case of ASPM. The discovery of MCPH genes will lead to a greater understanding of normal and abnormal human fetal cerebral cortex growth, giving potential insights into the question of how the mammalian cerebral cortex evolved and has become so predominant in humans, and the wherewithal to offer diagnostic, prenatal, and carrier testing for affected families.

\section{ACKNOWLEDGEMENTS}

We express our gratitude to the members of the family studied. This work has been funded by CAPES (Coordenação de Aperfeiçoamento de Pessoal de Nível Superior), FACEPE (Fundação de Amparo à Ciência e Tecnologia do Estado de Pernambuco), the Wellcome Trust, and the West Riding Medical Research Trust. We thank the Research Center Aggeu Magalhães (CPqAM) for permitting us to use their equipment for DNA extraction and the staff of HGMP for computational assistance.

Electronic Database Information. URLs for data in this article are as follows: Center for Medical Genetics, Marshfield Medical Research Foundation available at http://research.marshfieldclinic.org/genetics/ (for genetic linkage maps). Online Mendelian Inheritance in Man (OMIM): http://www.ncbi.nlm.nih.gov/omim. Human Gene Nomenclature Database, HUGO Gene Nomenclature Committee: http:// www.gene.ucl.ac.uk/nomenclature/ Draft human genome browser: http://genome.cse.ucsc.edu/. For primer creation (for novel microsatellite markers): http://www-genome.wi.mit.edu/cgi-bin/primer/ primer3_www.cgi.

\section{Authors' affiliations}

G F Leal, E O Silva, Instituto Materno-Infantil de Pernambuco (IMIP), Recife-PE, Brazil

E Roberts, D J Hampshire, C G Woods, Molecular Medicine Unit, University of Leeds, St James's University Hospital, Leeds LS9 7TF, UK S M R Costa, Departamento de Genética, Universidade Federal de Pernambuco, Recife-PE, Brazil

Correspondence to: $\operatorname{Dr}$ C G Woods, Molecular Medicine Unit, University of Leeds, St James's University Hospital, Leeds LS9 7TF, UK; msjcgw@leeds.ac.uk

\section{REFERENCES}

1 Hecht F, Kelly JV. Little heads: inheritance and early detection. J Pediatr 1979;95:731-32.

2 Baraitser M. Microcephaly. In: Motulsky AG, Bobrow M, Harper PS, Scriver C, eds. The genetics of neurological disorders. Vol 18. Oxford monographs on medical genetics. Oxford: Oxford Medical Publications, 1997:17-38

3 Ross JJ, Frias JL. Microcephaly. In: Vinken PJ, Bruyn GW, eds. Congenital malformations of the brain and skull. Part 1. Vol 30 Handbook of clinical neurology. Amsterdam: Elsevier Holland Biomedical Press 1977:507-24.

4 Van den Bosch J. Microcephaly in the Netherlands: a clinical and genetical study. Ann Hum Genet 1959:23:91-116.

5 Jackson AP, McHale DP, Campbell DA, Jafri $H$, Rashid Y, Mannan J Karbani G, Corry P, Levene MI, Mueller RF, Markham AF, Lench NJ, Woods CG. Primary autosomal recessive microcephaly (MCPH1) maps to chromosome 8p22-pter. Am J Hum Genet 1998;63:541-6.

6 Roberts E, Jackson AP, Carradice AC, Deeble VJ, Mannan J, Rashid Y, Jafri $\mathrm{H}$, McHale DP, Markham AF, Lench NJ, Woods CG. The second locus for autosomal recessive primary microcephaly $(\mathrm{MCPH} 2)$ maps to chromosome 19q13.1-13.2. Eur J Hum Genet 1999;7:815-20.

7 Moynihan L, Jackson AP, Roberts E, Karbani G, Lewis I, Corry P, Turner G, Mueller RF, Lench NJ, Woods CG. A third novel locus for primary autosomal recessive microcephaly maps to chromosome 9q34. Am Hum Genet 2000;66:724-7.

8 Jamieson CR, Govaerts C, Abramowicz M. Primary autosomal recessive microcephaly: homozygosity mapping of $\mathrm{MCPH} 4$ to chromosome 15. Am J Hum Genet 1999;65: 1465-9.

9 Pattison L, Crow YJ, Deeble VJ, Jackson AP, Jafri H, Rashid Y, Roberts E, Woods CG. A fifth locus for primary autosomal recessive microcephaly maps to chromosome 1q31. Am J Hum Genet 2000;67:1578-80.

10 Jamieson CR, Fryns JP, Jacobs J, Matthijs G, Abramowicz M. Primary autosomal recessive microcephaly: MCPH5 maps to 1q25-q32. Am J Hum Genet 2000;67: 1575-7.

11 Lander ES, Botstein D. Homozygosity mapping: a way to map human recessive traits with the DNA of inbred children. Science 1987;236: 1567-70

12 Reed PW, Davies JL, Copeman JB, Bennett ST, Palmer SM, Pritchard LE, Gough SCL, Kawaguchi Y, Cordell HJ, Balfour KM, Jenkins SC, Powell EE, Vignal A, Todd JA. Chromosome-specific microsatellite sets for fluorescence-based, semi-automated genome mapping. Nat Genet 1994; 7:390-5.

13 O'Connell JR, Weeks DE. PedCheck: a program for identification of genotype incompatibilities in linkage analysis. Am J Hum Genet 1998;63:259-66

14 Lathrop GM, Lalouel JM, Julier C, Ott J. Strategies for multilocus analysis in humans. Proc Natl Acad Sci USA 1984;81:3443-6.

15 Miyamoto M, Naruo K, Seko C, Matsumoto S, Kondo T, Kurokawa T. Molecular cloning of a novel cytokine cDNA encoding the ninth member of the fibroblast growth factor family, which has a unique secretion property. Mol Cell Biol 1993;13:4251-9.

16 Todo T, Kondo T, Nakamura S, Kirino T, Kurokawa T, Ikeda K. Neuronal localization of fibroblast growth factor-9 immunoreactivity in human and rat brain. Brain Res 1998;783:179-87

17 Jackson AP, Eastwood H, Bell SM, Adu J, Toomes C, Carr IM, Roberts E, Hampshire DJ, Crow YJ, Mighell AJ, Karbani G, Jafri H, Rashid Y, Mueller RF, Markham AF, Woods CG. Microcephalin: mutated in MCPH1 microcephaly. Am J Hum Genet 2002:71:136-42.

18 Bond J, Roberts E, Mochida GH, Hampshire DJ, Scott S, Askham JM, Springell K, Mahadevan M, Crow YJ, Markham AF, Walsh CA, Woods CG. ASPM is a major determinant of cerebral cortical size. Nat Genet 2002;32:316-20. 


\title{
Karak syndrome: a novel degenerative disorder of the basal ganglia and cerebellum
}

\author{
A Mubaidin, E Roberts, D Hampshire, M Dehyyat, A Shurbaji, M Mubaidien, A Jamil, \\ A Al-Din, A Kurdi, C G Woods
}

J Med Genet 2003;40:543-546

W e report a Jordanian Arab family where two sibs developed the classical clinical and radiological features of pantothenate kinase associated neurodegeneration (PKAN, formerly known as Hallervorden-Spatz disease) but in addition had an early onset cerebellar ataxia. ${ }^{12}$ Using polymorphic microsatellite markers we have shown that this family is not linked to the pantothenate kinase gene (PANK2) on chromosome $20 .{ }^{2}$ We hypothesise that the disorder, Karak syndrome, is novel and a member of the growing family of neurological diseases involving excess cerebral iron accumulation, for example, PKAN, neuroferritinopathy, aceruloplasminaemia, and Friedreich's ataxia. ${ }^{2-6}$

\section{CLINICAL STUDIES}

Both affected members (fig 1, IV.1 and IV.2) were the product of a normal pregnancy and birth and had normal developmental milestones and progress at school until disease onset at the age of 6 years. They developed an ataxic gait that was slowly progressive, and was associated with decreased school performance. At 8 years of age they developed inverted feet (calcaneovarus), which was associated with frequent falls. Around the age of 9 years, both started to have choreiform

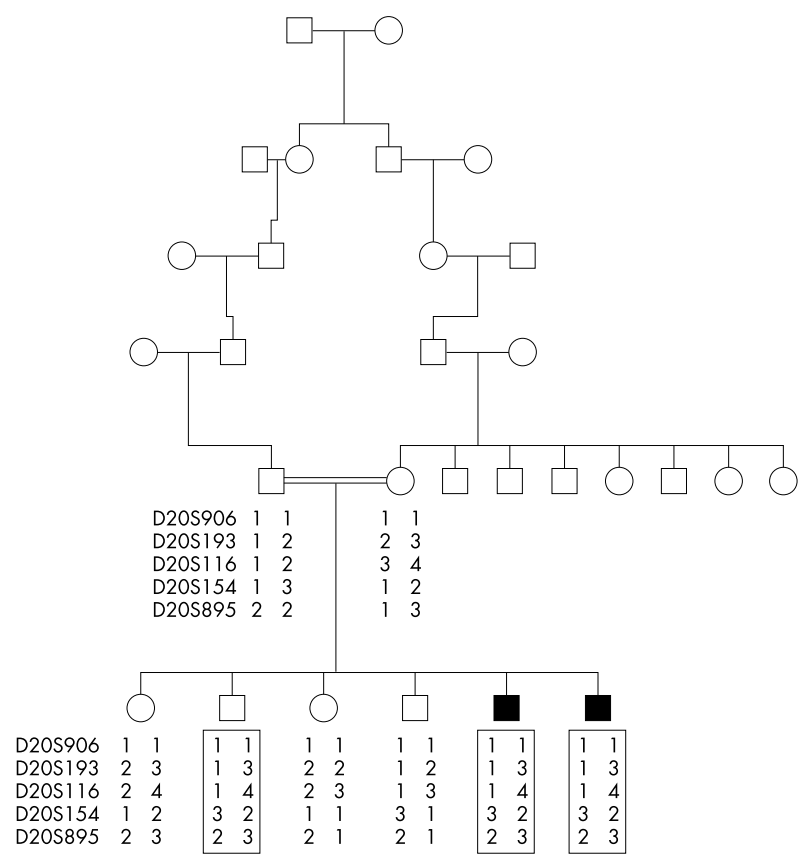

Figure 1 A simplified pedigree of the research family. Affected subjects with Karak syndrome are shown as shaded symbols. The closest link between family members is shown, although other more distant links also exist. The haplotype results for the polymorphic microsatellite markers tel-D20S906-D20S193-D20S1 16-

D20S482-D20S895-cen are shown under each person who was genotyped. The PANK2 gene lies between markers D20S193 and D20S116. The box highlights the allele results of the two affected males and an unaffected sib, all of whom have an identical heterozygous haplotype.

\section{Key points}

- Two brothers are reported with early onset progressive cerebellar ataxia, dystonia, spasticity, and intellectual decline.

- Neuroradiology showed cerebellar atrophy and features compatible with iron deposition in the putamen (including the "eye of the tiger sign") and substantia nigra.

- Diagnosis was compatible with pantothenate kinase associated neuropathy resulting from pantothenate kinase 2 mutation (PKAN due to PANK2) but linkage to PNAK2 was eliminated suggesting Karak syndrome to be a novel disorder.

- The "eye of the tiger" sign has previously only been reported to occur in PKAN due to PKAN2

movements of all four limbs, more marked in the upper limbs than in the lower limbs. By the age of 10 years the condition had progressed and they were unable to walk without assistance, and they left school soon after. Their mother found difficulty in feeding them because of swallowing problems after the age of 10 years and they were unable to dress, bathe, or feed themselves by their mid-teens. There were no visual or auditory symptoms or history of epilepsy. Both parents and four older sibs, two brothers and two sisters, were in good health. The parents were first cousins and came from an inbred family (fig 1). The family lived in Karak, a town in southern Jordan.

On examination at the ages of 12 and 14 years respectively, the patients were not dysmorphic and were well grown (height, weight, and head circumference between the 10th-50th centiles). No telangiectasia was found on skin or mucus membrane, nor were skeletal abnormalities detected. Pursuit eye movements showed bilateral limitation of upward gaze in both children; saccadic eye movements were abnormal with bilateral hypometric saccades. Visual acuity was normal, as were the pupillary responses, fundoscopy of the optic discs and retina, and slit lamp examination. Both affected children had dysarthric scanning speech with dystonic features. There was dystonic movement of the tongue and facial muscles and choreiform movement was present in both upper and lower limbs, being more marked in the lower limbs, along with dystonic posture of the distal feet. Significant bradykinesia was present in both upper and lower limbs. Muscle bulk was normal with no wasting or fasciculation. Generalised hypertonia was evident in both upper and lower limbs of a mixed spasticrigid type. Motor examination showed normal strength testing throughout. Evaluation of the different sensory modalities showed no abnormalities. Deep tendon reflexes were +2 and symmetrical, with bilateral extensor plantar responses. Dysmetria, past pointing, dysdiadochokinesia, and intentional tremor were bilateral and symmetrical. The gait was wide based, swayed in all directions, and had a spastic 


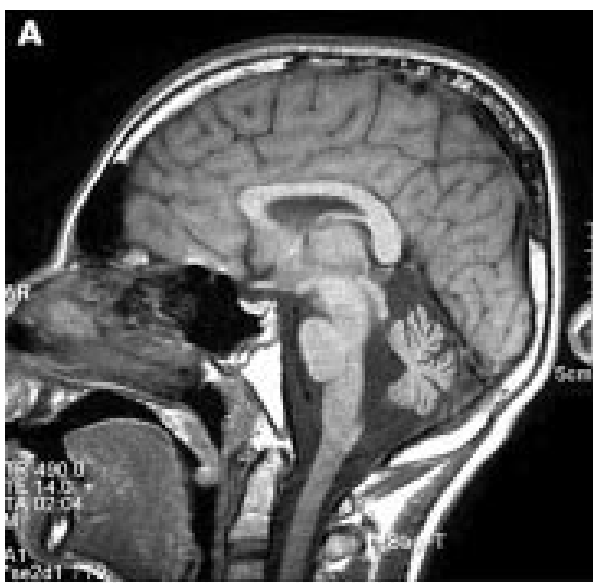

B
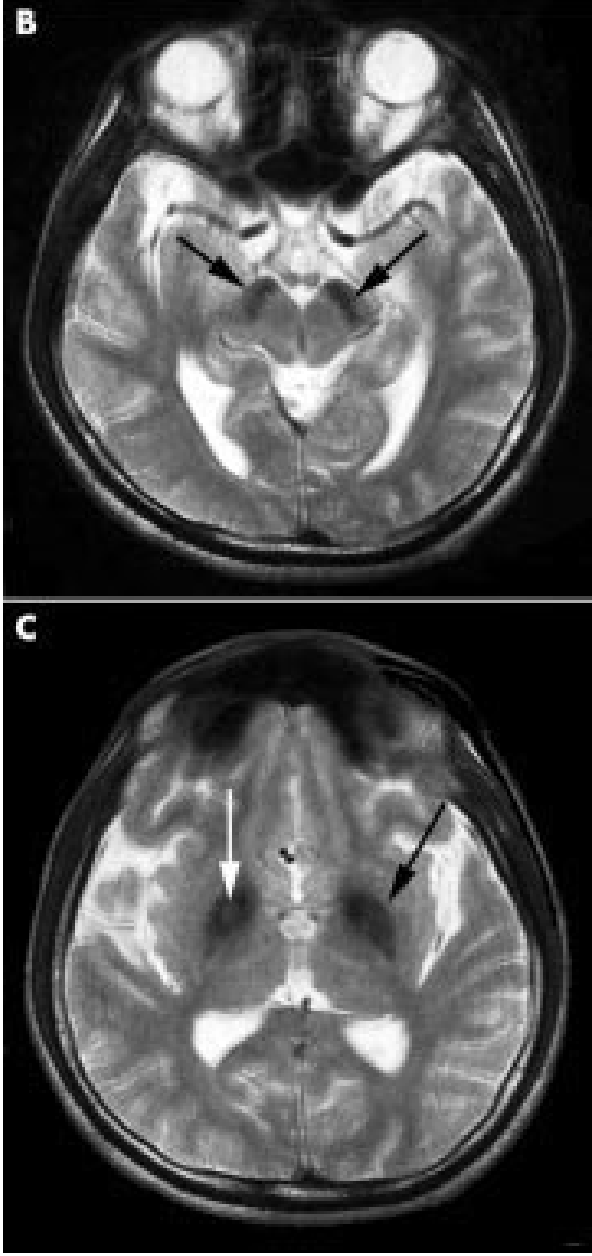

Figure 2 MRI T2 weighted images of the brain of the older affected sib. (A) A parasagittal view showing a moderate degree of pancerebellar atrophy. (B) Decreased signal intensity in the substantia nigra, indicated by a black arrow. (C) The "eye of the tiger" sign with decreased signal intensity in the globus pallidus, indicated by a black arrow, in the centre of which a small high signal spot was seen, indicated by a white arrow.

quality. Neurological examination showed evidence of impairment of cognitive functions and on the Wechsler Adult Intelligence Scale they both achieved less than 60 for verbal IQ.

The following investigations were normal in both children: blood count and film, haemoglobin electrophoresis, liver enzymes, lipid profile, urine testing, serum immunoglobulins, alpha-fetoprotein, serum B12, folate, copper, ceruloplasmin, creatinine phosphokinase, very long chain fatty acids, ferritin, urine organic acids (by gas chromatography and mass spectroscopy), audiogram, ECG, cardiac echo, chest radiographs, electromyography, motor and sensory conduction studies including studies of the late responses, and visual and brainstem evoked potentials. The potential differential diagnoses of PKAN, neuroferritinopathy, and aceruloplasminaemia were eliminated by these results. Muscle biopsy from the older affected child was normal with no evidence to suggest a mitochondrial myopathy. MRI studies of the brain of both affected sibs showed a moderate degree of pancerebellar atrophy (fig 2A). T2 weighted images showed markedly decreased signal intensity restricted to the substantia nigra (fig $2 \mathrm{~B}$ ) and the globus pallidus (fig 2C). In the centre of the globus pallidus a small high signal spot was seen ("eye of the tiger" sign) (fig 2C). There was no abnormal signal in the putamen, caudate nucleus, red nucleus, or dentate nucleus. Tl weighted inversion recovery images were not remarkable. The striking low attenuation on T2 weighted findings suggests an increased iron deposition in the globus pallidus, and is an obligatory radiological feature of PKAN caused by PANK2 gene mutations.

\section{MOLECULAR GENETIC STUDIES}

We performed linkage analysis between the family's disease and the PANK2 gene that causes PKAN. ${ }^{2}$ DNA was extracted using standard techniques from blood samples obtained from nuclear family members. Polymorphic microsatellite markers were sought that flanked the PANK2 gene by scrutiny of the Marshfield Linkage Maps, the DeCode genetic map, ${ }^{8}$ and the draft Human Genome Browser: D20S906-D20S193-PANK2 gene-D20S1 16-D20S482-D20S895 (at the following distances from 20pter: 1.5 Mb-3.3 Mb-3.85 Mb- 4.05 Mb-4.5 Mb-5.05 $\mathrm{Mb})$. PCR amplification of all markers was performed using a Roboseq 4200 (MWG BioTech Ltd). Amplified markers were pooled and electrophoresed on an ABI Prism 377 gene sequencer (Applied Biosystems) on $4.2 \%$ polyacrylamide gels, at $3000 \mathrm{~V}$ and $52^{\circ} \mathrm{C}$, for 2.5 hours. Fragment length analysis was undertaken using the ABI Prism Genescan and Genotyper 1.1.1 analysis packages. Fig 1 shows the family genotyping results. The two affected subjects and one of the unaffected sibs all had the same heterozygous results for the informative markers surrounding the PANK2 gene. This suggests that linkage of the disease to the PANK2 gene is very unlikely. A further implication of the result is that the affected sibs do not have two separate conditions, one PANK2 related and the other causing cerebellar ataxia. The results do not help determine if the condition is $\mathrm{X}$ linked or autosomal recessive. We also eliminated linkage to the mitochondrial ferritin gene on chromosome $5 \mathrm{q} 23^{9}$ (data not shown).

\section{DISCUSSION}

The disorder documented here presented at 6 years of age with cerebellar ataxia. Later, extra pyramidal motor features typical of classical PKAN due to PANK2 gene mutation developed and intellectual ability declined. There have been a few case reports in which ataxia is associated with PKAN, but none with ataxia as a presenting feature. ${ }^{10-12}$ However, in a large study of PKAN two groups were differentiated; firstly, cases with typical clinical symptoms (of what would have been once called Hallervorden-Spatz syndrome ${ }^{13}$ ) or atypical features with acanthocytosis, hypoprebetalipoproteinaemia and/or orofacial dyskinesia (known as HARP syndrome ${ }^{14-16}$ ) but all with the "eye of the tiger" sign on MRI brains scan and PANK2 mutations; secondly, a group of clinically atypical cases which did not have PANK2 mutations nor the "eye of the tiger sign" but did have hypodensity in the globus pallidus on T2 weighted MRI brain scans, cerebellar atrophy, and often evidence of iron deposition in the red nucleus and dentate nucleus. ${ }^{7}$ The family we report appears to have a demonstrably different condition from these two phenotypes because of the 


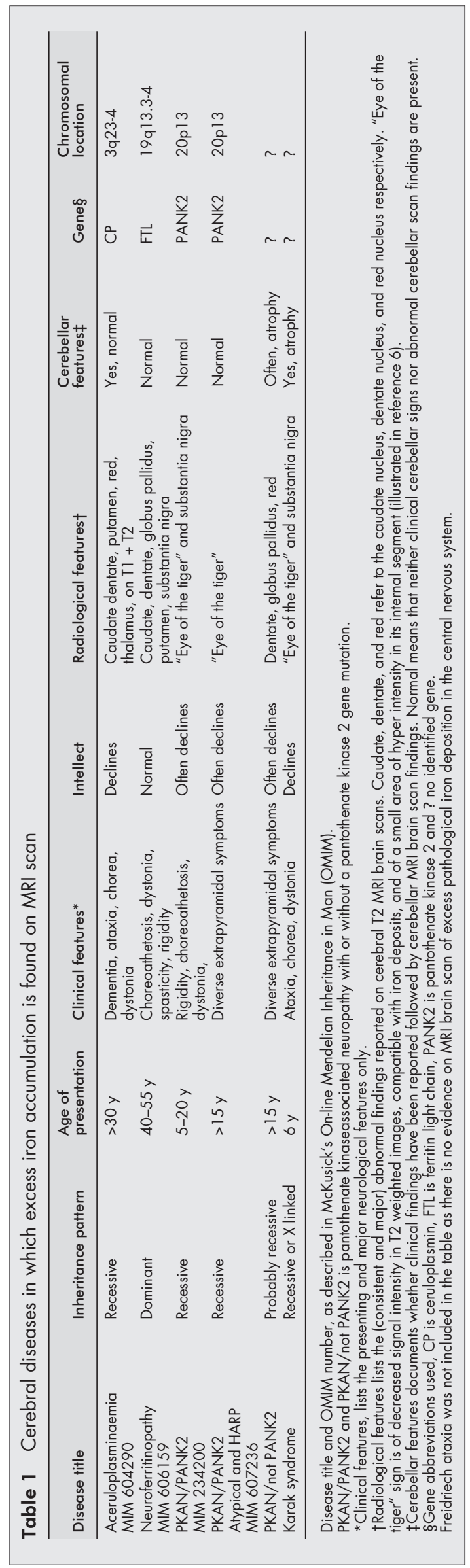

clinical presentation and the neuroradiological findings. The "eye of the tiger" sign is present as is hypodensity in the substantia nigra, but with no abnormal signal in the putamen, caudate nucleus, red nucleus, and dentate nucleus. Exclusion of linkage to the PANK2 gene provides further support that Karak syndrome is a distinct disorder. In the original paper mapping PKAN due to PANK2, family HS9 was the only unlinked family presented. However, insufficient clinical details are given to determine if this single Japanese male case was similar to the family we report. ${ }^{17} 18$

The highest concentration of iron in the brain is found within the basal ganglia (substantia nigra, putamen, caudate nucleus, and globus pallidus), red nucleus, and dentate nucleus. Cerebral iron accumulates with age, particularly in the basal ganglia. ${ }^{19}$ While iron is essential for normal brain function, free iron ions impose an oxidative stress on cells, owing to the production of oxygen free radicals, leading to cell damage. Cerebral diseases in which excess iron accumulation is shown on MRI scan are summarised in table 1. All cause clinical features of basal ganglia disease and all exhibit excess iron deposition in some or all of the sites where iron concentrations are the highest in the disease free state. Iron is stored predominantly complexed with ferritin within brain cells, and dysfunction of the ferritin light chain causes neuroferritinopathy. ${ }^{3}$ Ceruloplasmin is a ferroxidase with roles including ferric iron uptake by transferrin (which transports iron in the ferric state in the circulation) and dysfunction leads to aceruloplasminaemia. ${ }^{6}$ How mutations in the PANK2 gene, a brain specific CoA biosynthesis regulatory enzyme, cause pathological iron accumulation is unclear, but may relate to an accumulation of cysteine, which can chelate iron. A potential common pathogenic mechanism for neurological disease involving excess cerebral iron accumulation would be the release of free iron ions, either in excess or in a non-physiological situation or both. ${ }^{20}$ Because of this we sought, but did not find, linkage between the mitochondrial specific ferritin gene and Karak syndrome.

The inheritance pattern of Karak syndrome may be autosomal recessive or $\mathrm{X}$ linked recessive. The lack of other affected males in the matrilineal line and parental consanguinity favour recessive inheritance but clarification awaits further reports of the condition. We hypothesise that the disorder is novel and a member of the growing family of neurological disease involving excess pathological cerebral iron accumulation. Potentially, the gene mutated in Karak syndrome could be involved in iron sequestration, transport, storage, ferrous/ferric status control, intercalation of iron into enzymes, and oxidative respiration.

\section{ACKNOWLEDGEMENTS}

We express our gratitude to the members of the family studied. The Wellcome Trust and the West Riding Medical Research Trust have funded this work.

Electronic database information. For genetic linkage maps: Center for Medical Genetics, Marshfield Medical Research Foundation at http:// research.marshfieldclinic.org/genetics/ For data on polymorphic markers: Genome Database (GDB) at http://gdbwww.gdb.org/ For physical contig information of the human genome: the draft Human Genome Browser at http://genome.cse.ucsc.edu/ For genetic disease details: McKusick's Online Mendelian Inheritance in Man at http://www.ncbi.nlm.nih.gov/entrez/query.fcgi?db=OMIM

Authors' affiliations

A Mubaidin, M Dehyyat, A Shurbaii, A Kurdi, Neurology Department, King Hussein Medical Centre, PO Box 926442, Amman, Jordan 2 E Roberts, D Hampshire, C G Woods, Molecular Medicine Unit, University of Leeds, Clinical Sciences Building, St James's University Hospital, Beckett Street, Leeds, UK

M Mubaidien, Ophthalmology Department, King Hussein Medical Centre, Amman, Jordan

A Jamil, Radiology Department, King Hussein Medical Centre, Amman, Jordan 
A Al-Din, Department of Neurology, Pinderfields Hospital, Wakefield, UK

C G Woods, Clinical Genetics Department, St James's University Hospital, Beckett Street, Leeds, UK

Correspondence to: $\operatorname{Dr}$ C G Woods, Molecular Medicine Unit, University of Leeds, Clinical Sciences Building, St James's University Hospital, Beckett Street, Leeds LS9 7TF, UK; msjcgw@leeds.ac.uk

\section{REFERENCES}

1 Hallervorden J, Spatz H. Eigenartige Erkrankung im extrapyramidalen System mit besonderer Beteiligung des Globus Pallidus und der Substantia nigra. Z Ges Neurol Psychiat 1922;79:254-302.

2 Zhou B, Westaway SK, Levinson B, Johnson MA, Gitschier J, Hayflick SJ. A novel pantothenate kinase gene (PANK2) is defective in Hallervorden-Spatz syndrome. Nat Genet $2001 ; \mathbf{2 8 : 3 4 5 - 9}$

3 Curtis AR, Fey C, Morris CM, Bindoff LA, Ince PG, Chinnery PF, Coulthard A, Jackson M, Jackson AP, McHale DP, Hay D, Barker WA, Markham AF, Bates D, Curtis A, Burn J. Mutation in the gene encoding ferritin light polypeptide causes dominant adult-onset basal ganglia disease. Nat Genet 2001;28:350-4

4 Campuzano V, Montermini L, Molto MD, Pianese L, Cossee M, Cavalcanti F, Monros E, Rodius F, Duclos F, Monticelli A, Zara F, Cañizares J, Koutnikova H, Bidichandani SI, Gellera C, Brice A, Trouillas P, De Michele G, Filla A, De Frutos R, Palau F, Patel PI, Di Donato S Mandel J-L, Cocozza S, Koenig M, Pandolfo M. Friedreich's ataxia: autosomal recessive disease caused by an intronic GAA triplet repea expansion. Science 1996;271:1423-7.

5 Becker E, Richardson DR. Frataxin: its role in iron metabolism and the pathogenesis of Friedreich's ataxia. Int J Biochem Cell Biol 2001;33:1-10

6 Okamoto N, Wada S, Oga T, Kawabata Y, Baba Y, Habu D, Takeda $Z$, Wada Y. Hereditary ceruloplasmin deficiency with hemosiderosis. Hum Genet 1996:97:755-8.

7 Hayflick SJ, Westaway SK, Levinson B, Zhou B, Johnson MA, Ching KH, Gitschier J. Genetic, clinical, and radiographic delineation of Hallervorden-Spatz syndrome. N Engl J Med 2003;348:33-40.
8 Kong A, Gudbjartsson DF, Sainz J, Jonsdottir GM, Gudjonsson SA, Richardsson B, Sigurdardottir S, Barnard J, Hallbeck B, Masson G, Shlien A, Palsson ST, Frigge ML, Thorgeirsson TE, Gulcher JR, Stefansson K. A high-resolution recombination map of the human genome. Nat Gene 2002;31:241-7

9 Levi S, Corsi B, Bosisio M, Invernizzi R, Volz A, Sanford D, Arosio P, Drysdale J. A human mitochondrial ferritin encoded by an intronless gene. J Biol Chem 2001;276:24437-40.

10 Ylitalo V, Hagberg BA. Progressive ataxia in Swedish children: a re-evaluation study. Acta Neurol Scand 1994;89:299-302.

11 Sodeyama N, Arai M, Sanjoh N, Orimo S, Tamaki M. A case of Hallervorden-Spatz syndrome with marked atrophy of the brainstem and cerebellum. Rinsho Shinkeigaku 1993:33:525-9.

12 Ou SF, Chi CS, Shian WJ, Mak SC. Clinical and MRI study of the Ou SF, Chi CS, Shian WJ, Mak SC. Clinical and MRI study of the

3 Paediatr Sin 1994;35:439-43. Swaiman KF. Hall
$2001 ; 25: 102-8$.

14 Higgins JJ, Patterson MC, Papadopoulos NM, Brady RO, Pentchev PG Barton NW. Hypoprebetalipoproteinemia, acanthocytosis, retinitis pigmentosa, and pallidal degeneration (HARP syndrome). Neurology 1992;42:194-8.

15 Malandrini A, Cesaretti S, Mulinari M, Palmeri S, Fabrizi GM, Villanova M, Parrotta E, Montagnani A, Montagnani M, Anichini M, Guazzi GC. Acanthocytosis, retinitis pigmentosa, pallidal degeneration. Report of two Acanthocytosis, retinitis pigmentosa, pallidal degeneration. Report of two

16 Ching KH, Westaway SK, Gitschier J, Higgins JJ, Hayflick SJ. HARP syndrome is allelic with pantothenate kinase-associated neurodegeneration. Neurology 2002;58:1673-4.

17 Taylor TD, Litt M, Kramer P, Pandolfo M, Angelini L, Nardocci N, Davis $S$, Pineda M, Hattori H, Flett PJ, Cilio MR, Bertini E, Hayflick SJ. Homozygosity mapping of Hallervorden-Spatz syndrome to chromosome 20p12.3-p13. Nat Genet 1996;14:479-81

18 Taylor TD, Litt M, Kramer P, Pandolfo M, Angelini L, Nardocci N, Davis S, Pineda M, Hattori H, Flett PJ, Cilio MR, Bertini E, Hayflick SJ. Homozygosity mapping of Hallervorden-Spatz syndrome to chromosome 20p12.3-p13. Nat Genet 1997;16:109.

19 Erlach M, Ben-Shachar D, Riederer P, Youdim MB. Altered brain metabolism of iron as a cause of neurodegenerative diseases? J Neurochem 1994;63:793-807.

20 Nappi AJ, Vass E. Iron, metalloenzymes and cytotoxic reactions. Cell Mol Biol 2000;46:637-47.

\section{Myhre syndrome: new reports, review, and differential diagnosis}

\section{Burglen, D Héron, A Moerman, A Dieux-Coeslier, J-P Bourguignon, A Bachy, J-C Carel, V Cormier-Daire, S Manouvrier, A Verloes}

S everal conditions characterised by short fingers, reduced joint mobility, short stature, and muscular build with or without mental retardation have been delineated during the past 30 years: Moore-Federman syndrome, Myhre syndrome, acromicric dysplasia, geleophysic dysplasia, GOMBO syndrome, and LAPS (Laryngotracheal stenosis, Arthropathy, Prognathism and Short stature) syndrome. In 1980 Myhre et al ${ }^{1}$ reported two unrelated males with mental retardation, facial dysmorphism (short palpebral fissures, maxillary hypoplasia, prognathism, short philtrum, small mouth), short stature, brachydactyly, muscle hypertrophy, decreased joint mobility, mixed hearing loss, and cleft lip and palate in one of them. $X$ rays showed a thickened calvarium, hypoplastic iliac wings, broad ribs, and large, flattened vertebrae with large pedicles. Five further cases were reported. Mental retardation of variable severity was present in all patients. Three of the older patients had hypertension.

We report here four new unrelated patients who fit a diagnosis of Myhre syndrome, expanding the behavioural profile of the disorder, and discuss the differential diagnosis.

\section{CASE REPORTS}

\section{Patient 1}

Patient 1, a male, was the second child of healthy, non-consanguineous parents. The father was $181 \mathrm{~cm}$ tall and the mother was $165 \mathrm{~cm}$ tall. They were aged 40 and 34 years, respectively, at time of delivery. Birth weight was $2130 \mathrm{~g}$, length $44.5 \mathrm{~cm}$, and OFC $36 \mathrm{~cm}$ at 36 weeks' of gestation based on LMP ( 40 weeks based on morphological score of maturity). Recurrent hypoglycaemia requiring glucose infusion was recorded during the first weeks. Psychomotor development was normal, but dysarthria required long term speech therapy. He had bilateral deafness, with loss of $40 \mathrm{~dB}$ in low frequencies to $20 \mathrm{~dB}$ on the right side, and from $60 \mathrm{~dB}$ to $35 \mathrm{~dB}$ on the left side. MRI and CT showed bilateral dysplasia of the external semicircular canal. The stapedial footplate was bilaterally thick and, on the right side, fused with the oval window. This appearance was compatible with primary stapedial dysplasia or with otosclerosis. The absence of evolution of the hearing loss was considered as an argument for the dysplasia hypothesis. He wore a hearing aid. He had hypermetropia.

Progressive growth catch up occurred during the first year of life, reaching the 25 th centile curve, then he slowly came back to the 3rd centile curve. OFC stayed around the 25th centile. Repeated bone age studies always showed skeletal maturation concordant with chronological age. Longitudinal skeletal survey showed generalised brachydactyly with brachyphalangy and brachymetacarpalia, large epiphyses (notably the femoral heads and proximal phalanges of fingers 2 and 3), and mild platyspondylic appearance of the vertebral 


\section{Key points}

- Myhre syndrome is characterised by facial dysmorphism (short palpebral fissures, maxillary hypoplasia, prognathism, short philtrum, small mouth), short stature, brachydactyly, muscle hypertrophy, decreased joint mobility, hearing loss, and mental retardation.

- Radiological findings are a thickened calvarium, hypoplastic iliac wings, broad ribs and large, flattened vertebrae with large pedicles. Moore-Federman syndrome, acromicric dysplasia, geleophysic dysplasia and LAPS syndrome are the main differential diagnoses of Myhre syndrome.

- We report here four new unrelated patients who fit a diagnosis of Myhre syndrome. Absence of mental retardation was noted in one patient. Abnormal behaviour (impairment in social interactions and/or repetitive/ stereotypic behaviour) was noted in $2 / 4$ patients as in one previous report.

- Mixed hearing loss and hypertension (4/5 patients over 16 years old) seem constant in older patients. Thick skin was noted in three of our patients as in 3/7 previously reported patients and could be a major feature of Myhre syndrome.

- Paternal age was increased in half of the reported cases, suggesting a new mutation of an autosomal dominant gene. $X$ linked transmission cannot be excluded since all reported cases $(11 / 11)$ were males.
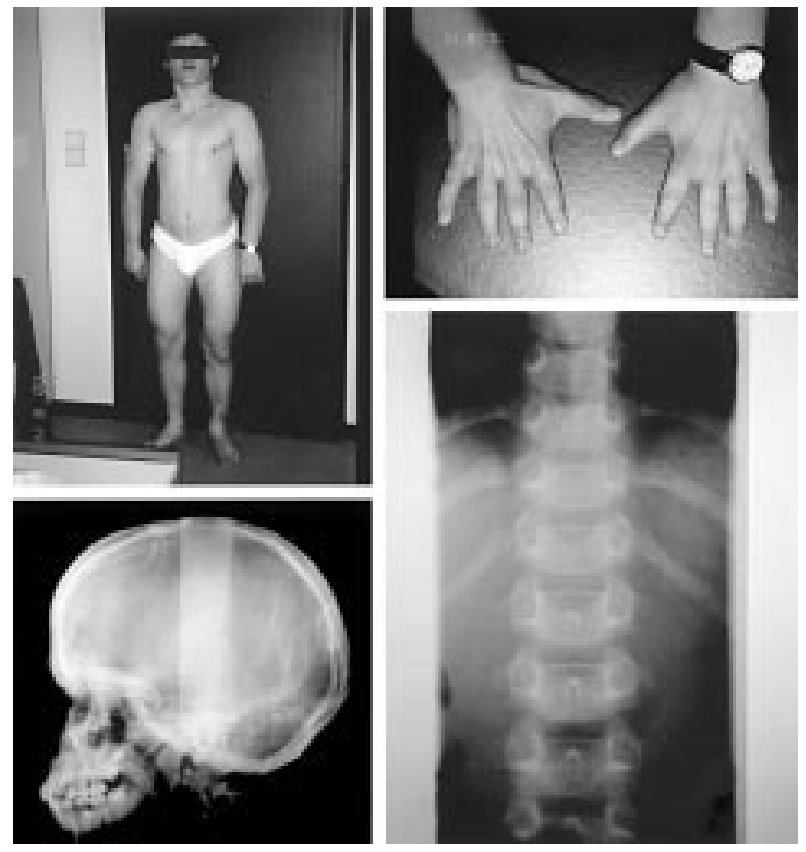

Figure 1 Patient 1. (A) Muscular build. (B) Brachydactyly. (C) Thickened calvarium. (D) Large vertebral pedicles.

bodies with irregular endplate (fig 1D). The pelvis was narrow. The calvarium and ribs were not thickened (fig IC).

Bilateral cryptorchidism was surgically corrected at the age of 3. Puberty began at 13 years, but at the age of 17, pubertal development scored only Tanner stage P4 G4 with a subnormal testicular volume of $10 / 15 \mathrm{ml}$, which prompted endocrinological studies. These showed normal testosterone levels $(5.61 \mathrm{ng} / \mathrm{ml})$, high FSH levels ( $16.0 \mathrm{mUI} / \mathrm{ml}$, normal $<11$ ), and normal LH level. This was compatible with primary (hypergonadotrophic) hypogonadism, possibly related to germinal cell aplasia (Sertoli cell only syndrome) or to another anomaly of spermatogenesis or anomalies of the FSH receptor.

When evaluated at the age of 20 he was a university student. He had difficult social relationships. He was $154 \mathrm{~m}$ tall and OFC was $56.5 \mathrm{~cm}$ (fig 1A). The facial dysmorphism included a square face, upward slanting eyebrows, short nose, very short philtrum, narrow mouth, and a large, prognathic chin. He had short hands with mild cutaneous syndactyly (fig 1B), and short feet with Y shaped syndactyly of toes 2 and 3. The skin was hard. There was generalised joint limitation, noted by the age of 10 and slowly worsening with time, and generalised muscular hypertrophy with extremely hard muscles. Neurological examination was normal, but osteotendinous reflexes were very weak. At the ages of 10 and 20, CK, EMG, and motor conduction velocity were normal. Muscle light microscopy at the age of 10 showed no abnormality. Hypertension (up to 170/100) was noted on different occasions during the last two years; no specific reason could be found. Echocardiography was normal. High resolution G banding and FISH with subtelomeric probes were normal.

\section{Patient 2}

This boy was the second child of healthy, nonconsanguineous, young parents. Heights of the parents were $176 \mathrm{~cm}$ (father) and $160 \mathrm{~cm}$ (mother). The two sisters were healthy. At birth at 41 weeks' gestation, weight was $2130 \mathrm{~g}$, length $42 \mathrm{~cm}$, and OFC $32 \mathrm{~cm}$. Neonatal examination showed left cryptorchidism, short hands, and slight facial dysmorphism. During the first year, growth was retarded and gluten allergy was suspected. A gluten free diet had no effect. Motor development was normal but later learning disabilities were noted at school. When he was 9 years old hearing loss was suspected and confirmed by audiogram. Hearing improved with bilateral hearing aids. He was admitted to an institution for deaf persons but poor school performances were noted. At the age of 9, height was $113 \mathrm{~cm}$ (less than the 3rd centile), regularly on this curve since birth. Endocrinological investigations showed normal GH, IGFl, T4, and TSH levels. Chromosomal analysis was normal, 46,XY. Bone age was 8 years. Echocardiography was normal. A diagnosis of acromicric dysplasia was suspected but facial dysmorphism was strikingly different. A few weeks later, growth velocity improved rapidly, and testis growth began. Endocrinological studies (testosterone and LH-RH test) confirmed central precocious puberty. Cerebral MRI was normal. Gonadotrophin releasing hormone agonist therapy was started and continued until the age of 14 .

Clinical findings at 14 years showed short stature $(136 \mathrm{~cm}$, less than the $3 \mathrm{rd}$ centile), weight $44.5 \mathrm{~kg}$ (25th centile), and OFC $55.5 \mathrm{~cm}$ (50th centile). He had facial dysmorphism with small palpebral fissures, small round ears, a broad nasal bridge, short philtrum, small mouth, marked prognathism, and a short neck. The hands were short with brachydactyly. He had a striking muscular build. Moderate joint limitation was present in the elbows and the skin was very thick (fig 2). Ophthalmological examination showed hypermetropia and astigmatism. Longitudinal radiological findings were thick calvarium, platyspondyly with irregular endplate, very large vertebral pedicles, and large epiphyses (hands, femoral heads).

\section{Patient 3}

This male patient was the second child of a 32 year old G2 P2 mother and a 38 year old father. The brother was healthy and family history was negative. During the pregnancy, ultrasonography showed short femora at 31 weeks' gestation. Fetal blood sampling was performed and karyotype was normal. Birth weight at 39 weeks' gestation was $2350 \mathrm{~g}$, birth length 44 $\mathrm{cm}$, and OFC $32 \mathrm{~cm}$. Psychomotor development was normal in 

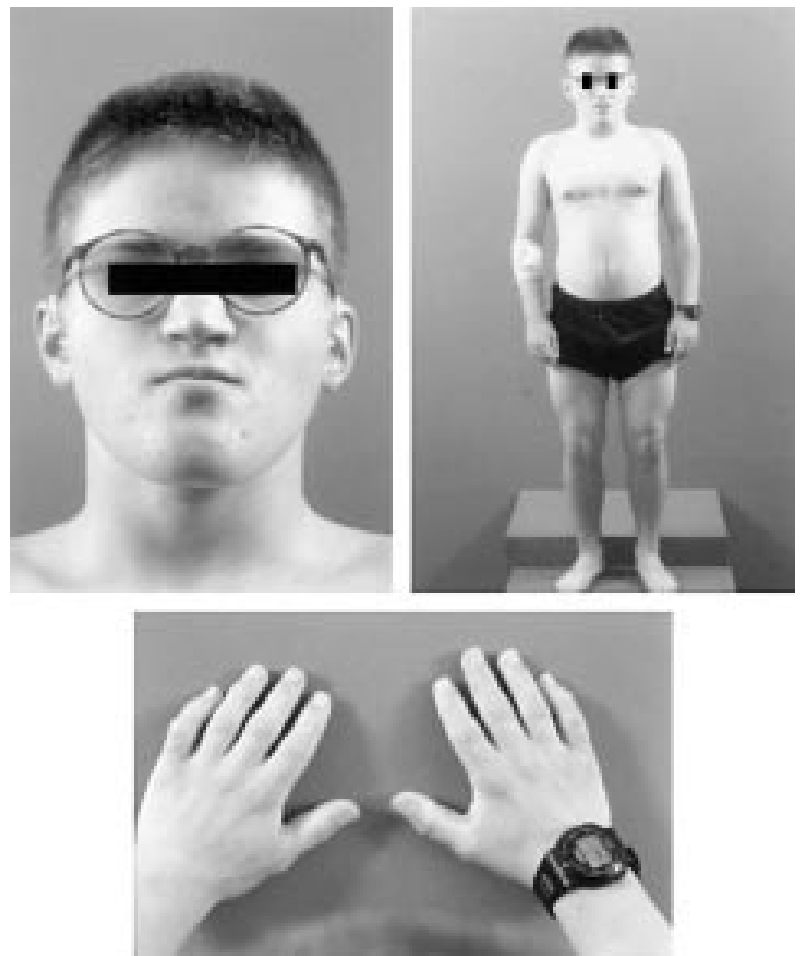

Figure 2 Patient 2. (A) Facial dysmorphism, short philtrum, thin lips. (B) Muscular build, joint limitation (elbows). (C) Brachydactyly.

the first months but language was delayed. At 2 years auditory evoked potentials showed hypoacusis. Hearing improved partially after transtympanic drains. Behaviour was abnormal. He had a severe impairment in social interaction (gaze and physical contact avoidance), abnormal communication (repetitive/ stereotypic language), repetitive/stereotypic activities, difficulties with new situations, attention deficit, hyperactivity, and slight auto-aggressiveness. No standardised diagnosis of autism was available. These difficulties partially improved with time and psychotherapy. Growth was on the 20th centile in the first five years.

At 5 years, height was $1 \mathrm{~m}$ ( 5 th centile), weight $19 \mathrm{~kg}$ (60th centile), and OFC $50 \mathrm{~cm}$ (25th centile). Clinical examination showed muscular hypertrophy and facial dysmorphism. He had brachycephaly, short palpebral fissures, deep set eyes, low set and small, round ears, a short philtrum, slightly convex profile of the nose, thin lips, and prognathism. The fingers were short with distal phalangeal hypoplasia. Extension of the elbows, knees, and ankles and pronosupination were limited. Achilles tendons were shortened but he had no spasticity or pyramidal signs. The skin was thick.

High resolution G band analyses, FISH with subtelomeric probes, cerebral CT scan, cardiac and renal ultrasound, and CK were normal. Ophthalmological examination showed hypermetropia, astigmatism, and strabismus. Skeletal $x$ ray showed large vertebral pedicles and bone age was retarded (fig 3 ).

\section{Patient 4}

This male patient was born to healthy, non-consanguineous parents. He had a healthy older sister and three healthy half sibs from his mother and a healthy half sister from his father. The father was $168 \mathrm{~cm}$ tall and the mother was $153 \mathrm{~cm}$ tall. They were respectively aged 43 and 35 at the time of delivery. At birth weight was $2500 \mathrm{~g}$, length was $47 \mathrm{~cm}$, and OFC $32 \mathrm{~cm}$ at 38 weeks' of gestation. Global hypertonia and brachydactyly were noticed. Clinical findings at 5 years of age showed short stature ( $1 \mathrm{~m},-2 \mathrm{SD}$ ) with normal OFC ( $53 \mathrm{~cm},+1 \mathrm{SD})$, "muscular" habitus, and thick skin. A peculiar square face was
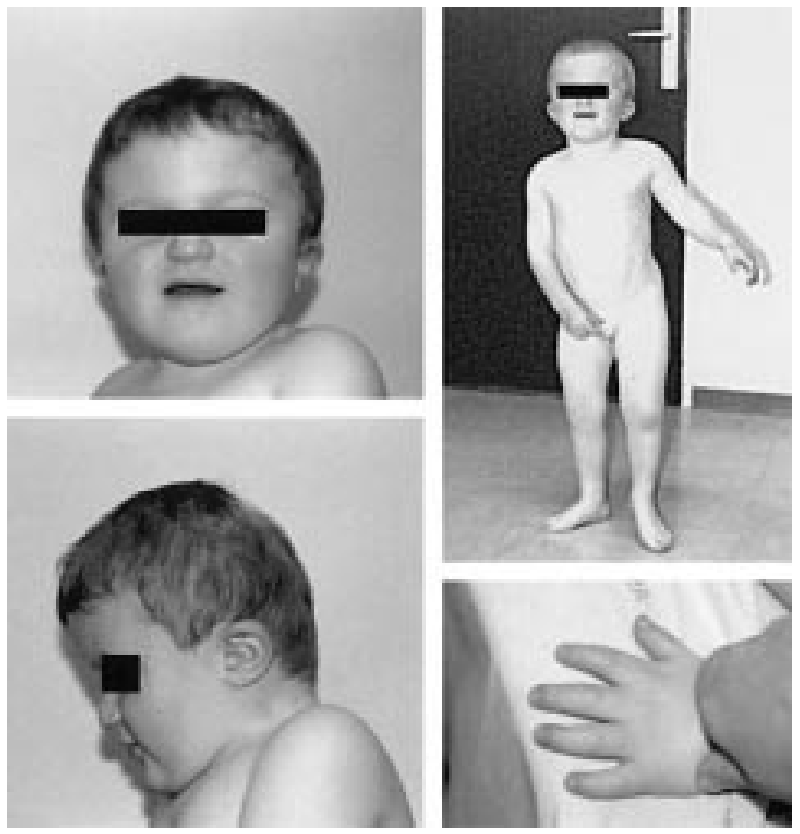

Figure 3 Patient 3. (A) Facial dysmorphism: short palpebral fissures, short philtrum, and thin lips. (B) Short neck and small ears. (C) Muscular build. (D) Brachydactyly.
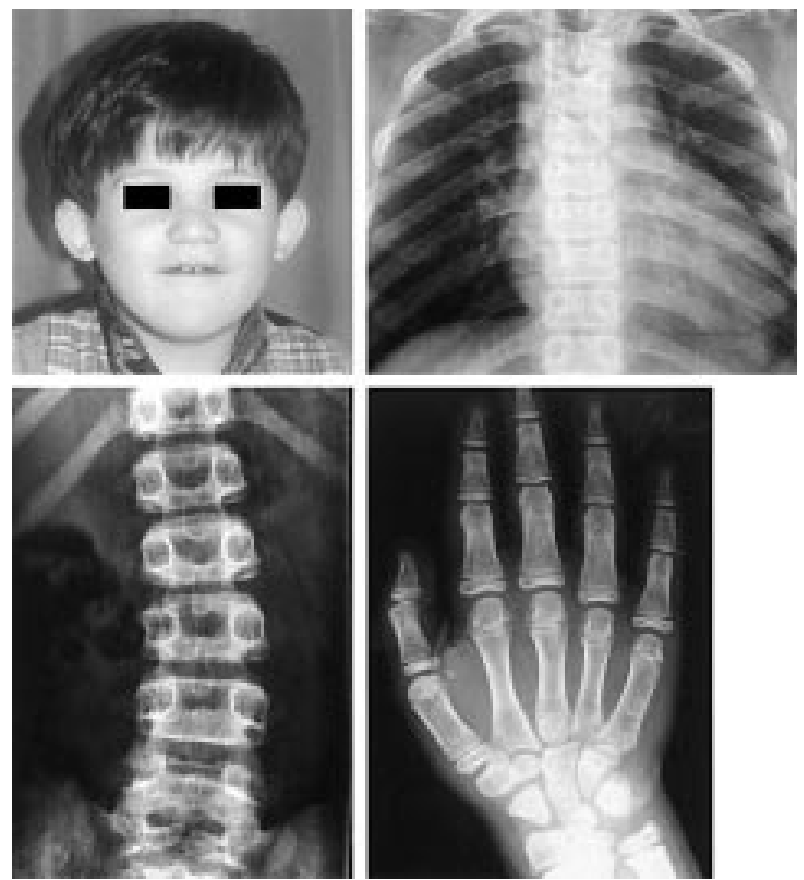

Figure 4 Patient 4. (A) Facial dysmorphism: short palpebral fissures, short philtrum, thin lips, and prominent mandible. (B) Broad ribs. (C) Large vertebral pedicles. (D) Brachydactyly.

observed with short palpebral fissures, short and broad nose, very short and marked philtrum, narrow mouth with thin lips, large, prognathic chin, and small, dysplastic, prominent ears. He had short hands with brachydactyly and short feet with slight II-III syndactyly. Osteotendinous reflexes were very weak. Psychomotor development was delayed and behaviour was abnormal with sleeping difficulties, frustration intolerance, hyperactivity, encopresis, and aggressiveness towards himself and others. Ophthalmological examination showed bilateral subcapsular cataract, which was surgically removed at the age of 6 years. Abdominal ultrasonographic scan 


\begin{tabular}{|c|c|c|c|c|c|c|c|c|c|c|c|c|}
\hline & \multicolumn{2}{|c|}{ Myhre et $a i^{1}$} & \multirow{2}{*}{$\begin{array}{l}\text { Soliak et af } \\
\text { Patient } 1\end{array}$} & \multicolumn{2}{|c|}{ Garcia-Cruz et $a^{\beta}$} & \multirow{2}{*}{$\begin{array}{l}\text { Whiteford et al } \\
\text { Patient } 1\end{array}$} & \multirow{2}{*}{$\begin{array}{l}\text { Titomanlio et }\left.a\right|^{5} \\
\text { Patient } 1\end{array}$} & \multicolumn{4}{|l|}{ This report } & \multirow{2}{*}{$\begin{array}{l}\text { Total or } \\
\text { mean* }\end{array}$} \\
\hline & Patient 1 & Patient 2 & & Patient 1 & Patient 2 & & & Patient 1 & Patient 2 & Patient 3 & Patient 4 & \\
\hline Paternal age at birth & 37 & 38 & 42 & 32 & 23 & 32 & 33 & 40 & 28 & 38 & 43 & $35^{\star}$ \\
\hline Sex & M & M & M & M & M & $M$ & M & M & M & M & M & $11 \mathrm{M}$ \\
\hline \multicolumn{13}{|l|}{ General } \\
\hline Birth weight (g) & 2100 & 2900 & 3200 & 2200 & 2100 & 2870 & 2110 & 2100 & 2130 & 2.350 & 2.500 & $2.4^{*}$ \\
\hline Birth height & $?$ & $?$ & $?$ & $?$ & $?$ & $?$ & $?$ & 44.5 & 42 & 44 & 47 & $44.4^{*}$ \\
\hline $\begin{array}{l}\text { Height in SD } \\
\text { (adult height) }\end{array}$ & $\begin{array}{l}-5.5 \\
(140 \mathrm{~cm})\end{array}$ & $\begin{array}{l}-4.5 \\
(146 \mathrm{~cm})\end{array}$ & $\begin{array}{l}-4.5 \\
(146 \mathrm{~cm})\end{array}$ & $\begin{array}{l}-6 \\
(139 \mathrm{~cm})\end{array}$ & -3 & $<-2$ & -4 & $\begin{array}{l}-2 \\
(154 \mathrm{~cm})\end{array}$ & -3.6 & -2 & -2 & $-2 /-6$ \\
\hline \multicolumn{3}{|l|}{ Craniofacial features } & 16 & 18 & 6 & 13 & 14 & 20 & 14 & 5 & 10 & $14.3^{*}$ \\
\hline OFC (SD) & -1 & -1.5 & $?$ & -1.5 & M & +1.5 & +1 & -1 & +0.5 & -1 & 0 & $-1 /+1.5$ \\
\hline Ptosis & $?$ & $?$ & $?$ & $?$ & - & - & $?$ & - & + & + & slight & \\
\hline Short palpebral fissures & + & + & + & + & + & + & + & + & + & + & + & $11 / 11$ \\
\hline Midface hypoplasia & + & + & + & - & + & + & $?$ & + & + & + & + & $9 / 10$ \\
\hline Short philtrum & + & + & + & + & + & + & + & + & + & + & + & $11 / 11$ \\
\hline Narrow mouth & + & + & + & + & + & + & + & + & + & + & + & $11 / 11$ \\
\hline Thin upper lip & + & + & + & + & + & + & + & + & + & + & + & $11 / 11$ \\
\hline Prognathism & + & + & + & $?$ & + & $?$ & + & + & + & + & + & $9 / 9$ \\
\hline Cleft lip & + & - & - & - & - & - & - & - & - & - & - & $1 / 11$ \\
\hline Small ears & $?$ & $?$ & $?$ & $?$ & + & $?$ & $?$ & + & + & + & + & $5 / 5$ \\
\hline \multicolumn{13}{|l|}{ Skeletal anomalies } \\
\hline Brachydactyly & + & + & + & + & + & + & + & + & + & + & + & $11 / 11$ \\
\hline Thick calvaria & + & + & + & + & + & + & + & - & + & $?$ & + & $9 / 11$ \\
\hline Joint limitations & + & + & + & + & + & + & + & + & + & + & + & $11 / 11$ \\
\hline Broad ribs & + & + & + & + & + & + & $?$ & - & + & ? & + & $8 / 9$ \\
\hline Narrow pelvis & + & + & + & + & + & + & + & + & + & ? & + & $10 / 10$ \\
\hline Thick femoral necks & - & - & + & + & - & + & $?$ & - & ? & ? & + & $4 / 8$ \\
\hline Large epiphyses & $?$ & $?$ & $?$ & $?$ & $?$ & $?$ & $?$ & + & + & ? & + & $3 / 3$ \\
\hline Mild platyspondyly & + & + & - & + & + & + & $?$ & + (regress) & + & + & + & $9 / 10$ \\
\hline Large pedicles & + & + & + & $?$ & $?$ & + & + & - & + & + & + & $8 / 9$ \\
\hline \multicolumn{13}{|l|}{ Neuromuscular } \\
\hline $\mathrm{IQ}$ & 45 & $35-50$ & 75 & Low & Low & Low & Low & Normal & Low & $50-60$ & $55-60$ & \\
\hline Behaviour & , & $?$ & 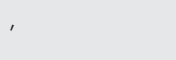 & $?$ & $?$ & $?$ & autistic & $\begin{array}{l}\text { Difficult } \\
\text { relationships }\end{array}$ & $?$ & $\begin{array}{l}\text { Repetitive/ stereotypic } \\
\text { behavior, Hyperactivity }\end{array}$ & Hyperactivity encopresis & \\
\hline Muscular hypertrophy & + & + & + & + & + & + & + & + & + & + & + & $11 / 11$ \\
\hline Muscle histology & $?$ & $?$ & Normal & Minor changes & $?$ & Normal & Minor changes & Normal & $?$ & ? & $?$ & \\
\hline EMG/muscle ultrasound & $?$ & $?$ & EMG myopathic & Normal & ? & $\begin{array}{l}\text { Myopathic US } \\
\text { changes }\end{array}$ & EMG neurogenic & EMGnNormal & ? & ? & ? & \\
\hline \multicolumn{13}{|l|}{ Miscellaneous } \\
\hline Very thick skin & $?$ & $?$ & + & + & $?$ & $?$ & + & + & + & + & + & $7 / 7$ \\
\hline Deafness & + & + & + & $-100 \mathrm{~dB}$ & - & + & Mild & + & + & + & - & $9 / 11$ \\
\hline Abnormal inner ear & $?$ & $?$ & $?$ & $?$ & $?$ & Ossicular fixation & $?$ & + & $?$ & $?$ & $?$ & \\
\hline $\begin{array}{l}\text { Ophthalmological } \\
\text { anomalies }\end{array}$ & Hyperm & Hyperm & Hyperm & $?$ & $?$ & Cataract & $?$ & Hyperm & Hyperm & Hyperm & Cataract & $8 / 8$ \\
\hline Heart malformation & + & ASD & - & - & - & PDA, PPS & $\begin{array}{l}\text { Left atrium mild } \\
\text { dilatation }\end{array}$ & - & - & - & $\begin{array}{l}\text { Aortic and pulmonar } \\
\text { valve stenosis }\end{array}$ & $5 / 11$ \\
\hline Kidney malformation & - & - & - & - & - & - & - & - & - & - & Right kidney agenesia & $1 / 11$ \\
\hline Hypertension & + & - & + & + & - & ? & - & + & - & - & - & $4 / 10$ \\
\hline Inguinal hernia & + & - & - & - & - & - & + & - & - & - & - & $2 / 11$ \\
\hline Puberty & $?$ & $?$ & Normal & Delayed & $?$ & ? & $?$ & Delayed & Precocious & & Precocious & \\
\hline Hypospadias & + & - & - & - & - & - & - & - & - & - & - & $1 / 11$ \\
\hline Cryptorchidism & + & + & - & $?$ & - & - & + & + & + & - & - & $5 / 10$ \\
\hline
\end{tabular}


Table 2 Differential diagnosis of Myhre syndrome

\begin{tabular}{|c|c|c|c|c|c|}
\hline & Myhre & LAPS & Geleophysic dysplasia & Acromicric dysplasia & Moore-Federman \\
\hline Short stature & + & + & + & + & + \\
\hline Brachydactyly & + & + & + & + & + \\
\hline Joint limitation & + & + & + & + & + \\
\hline Muscular hypertrophy & + & - & - & $+1-$ & - \\
\hline Mental retardation & Frequent & Learning difficulties & - & - & - \\
\hline Deafness & $+9 / 11$ & $+3 / 5$ & - & - & - \\
\hline Abnormal skin & + & + & + & - & + \\
\hline Laryngotracheal stenosis & - (too young ?) & + (severe adult onset) & + (childhood onset) & + (childhood onset) & - \\
\hline Hepatomegaly & - & - & + & - & + \\
\hline Cardiac disease & Congenital malformations & Pericarditis & Progressive cardiac valve disease & - & $+/-$ \\
\hline Transmission & $A D ? X$ linked? (1 1M/OF) & $A D ?(1 M / 4 F)$ & $A R$ & $A D$ & $A D$ \\
\hline
\end{tabular}

showed right kidney agenesis and cardiac ultrasonographic scan showed moderate aortic stenosis. Hearing was normal. Karyotype was normal 46,XY. Subsequently growth followed the -2 SD curve, behavioural difficulties persisted, but sleeping improved. Generalised muscular hypertrophy and "pugilistic" posture were more prominent. Progressive joint limitation was observed with enlargement of the big joints and limited extension of the elbows, knees, ankles, fingers, and limited pronosupination. At 10 years of age precocious central puberty occurred with advanced bone age. Cerebral MRI was normal (fig 4).

\section{DISCUSSION}

Myhre et al ${ }^{1}$ reported two unrelated males with mental retardation, facial dysmorphism (short palpebral fissures, maxillary hypoplasia, prognathism, short philtrum, small mouth), short stature, brachydactyly, muscle hypertrophy, decreased joint mobility, mixed hearing loss, and cleft lip and palate in one of them. $X$ rays showed a thickened calvarium, hypoplastic iliac wings, broad ribs, shortened tubular bones, and large, flattened vertebrae with large pedicles. Five further cases were reported. ${ }^{2-5}$ The four patients reported here fit a diagnosis of Myhre syndrome.

Clinical data on Myhre syndrome patients are presented in table 1. The most important features are low birth weight (mean $2415 \mathrm{~g}$ ), variable short stature, facial dysmorphism (midface hypoplasia, narrow palpebral fissures, short philtrum, and prognathism), short hands, muscular build, very peculiar thick skin, and joint limitation. Birth length was not previously reported but short stature was of prenatal onset in our four patients. Mental retardation is frequent but was absent in our patient 1 . However, this patient had behavioural disturbances with difficult relationships. Abnormal behaviour was noted in the patient reported by Titomanlio et al who was diagnosed as autistic. No standardised diagnosis of autism was available for our patient 3 but he had at least an "autisticlike condition". Further observations with a careful description of behaviour are needed in order to know if autistic or other behavioural disturbances are features of Myhre syndrome. Deafness is a frequently reported feature that seems constant in older patients, suggesting that hearing loss could be progressive. Hearing loss is mixed in most cases. One of our patients had cataracts, as did one previously reported patient. ${ }^{4}$ Agenesis of one kidney is reported for the first time and could be a rare feature like cleft lip that was reported in one case. Thickness of the skin is present in 6/11 patients and is a major feature of Myhre syndrome. In patient 3, thickness of the skin was noted as early as 3 years old. No skin biopsy was performed in our patients. Titomanlio et al $5^{5}$ reported dermis thickening with collagen infiltration in their patient. Four of 11 patients had hypertension. All were between 16 and 20 years old. This feature is possibly not present in younger children. Blood pressure had to be regularly measured in patients with Myhre syndrome. One hypothesis could be abnormal arterial stiffness but this remains to be confirmed by specific studies. Another clinical feature of interest is the abnormal onset of puberty observed in three of our cases, two showing early onset (before the age of 9 years) and another one showing delayed puberty with hypergonadotrophic hypogonadism. Although these phenotypic manifestations are discordant, they may point to a disturbance in the hypothalamohypophyso-gonadal axis that should be investigated in further cases.

Several syndromes were transiently considered in the differential diagnosis of our patients. OSMED syndrome shows megaepiphyses, irregular vertebral bodies, and deafness, but can be distinguished by a different facial dysmorphism (micrognathia), metaphyseal involvement, and progressive carpal fusion. ${ }^{6}$ Phenotypic similarities were noted between Myhre syndrome and GOMBO syndrome, ${ }^{78}$ but the latter has been shown to result from a cryptic translocation between chromosomes 3p and 22q. ${ }^{9}$ Telomeric FISH analyses performed in two of our patients detected no cryptic rearrangement. Moore-Federman syndrome, ${ }^{10}$ acromicric dysplasia, ${ }^{11}$ 12 geleophysic dysplasia, ${ }^{13}$ and LAPS syndrome $^{1516}$ are the main differential diagnoses of Myhre syndrome. Table 2 summarises the similarities and differences between these entities.

Acromicric dysplasia is characterised by short stature below 3 SD noted after the age of 2 years, short and stubby hands and feet, and mild dysmorphic signs, including narrow palpebral fissures, full cheeks, and a short and anteverted nose. Radiological anomalies include short metacarpals (especially 2-5) with an internal notch on the second one, short and broad proximal and medial phalanges, cone shaped epiphyses, internal notch on the femoral necks, and delayed bone maturation. Hoarse voice, generalised joint limitation, and muscular build have recently been added to the clinical picture of acromicric dysplasia. ${ }^{12}$ Microscopically, there is disorganised cartilage, abnormal organisation of collagen, and accumulation of glycogen in most chondrocytes. The distinction between acromicric dysplasia and the Moore-Federman syndrome, which are both dominantly inherited, is still a disputed issue, with both lumping and splitting suggested. ${ }^{12}{ }^{17}$ There is now convincing evidence to reject lumping with the recessively inherited geleophysic dysplasia as previously suggested. ${ }^{18}$ There are obvious similarities between acromicric dysplasia and Myhre syndrome. Nevertheless, Myhre syndrome can be distinguished on the basis of facial features, IUGR, mental retardation, and on the severity of muscular and cutaneous involvement. Geleophysic dysplasia ${ }^{13}$ is characterised by short stature with a "happy looking" facial appearance, short hands, joint contractures, thickened skin, hepatomegaly, and cardiac valve dysplasia. This is considered to be a storage disease with progressive worsening and a poor prognosis. Storage vacuoles are present in hepatocytes, chondrocytes, and fibroblasts. ${ }^{14}$ Myhre syndrome and geleophysic dysplasia share some features but hepatomegaly and 
cardiac valve dysplasia have never been reported in patients with Myhre syndrome even in older subjects. Facial dysmorphism is different with a short philtrum, small mouth, and frequent prognathism in Myhre syndrome. Additionally, short stature is postnatal in geleophysic dysplasia but was of prenatal onset in all our Myhre patients. Figuera ${ }^{19}$ suggested that the patient reported by Rosser et al as having geleophysic dysplasia had Myhre syndrome. Nevertheless, as pointed out by McGaughran and Donnai ${ }^{20}$ geleophysic dysplasia seems a more convincing diagnosis for this patient who had hepatomegaly, thickened mitral valve, and "geleophysic dysplasia facial dysmorphism".

Hopkin $e t$ a $l^{15}$ described three patients with a disorder characterised by short stature, joint limitation, and progressive adult onset laryngotracheal stenosis. Lindor $e t a l^{16}$ reported two further patients and coined the acronym LAPS syndrome for Laryngotracheal stenosis, Arthropathy, Prognathism, and Short stature. Short stature, brachydactyly, joint limitation, prognathism, small, round ears, short palpebral fissures, abnormal skin, thick calvaria, and deafness are observed in Myhre and LAPS syndromes. A disturbance in the hypothalamo-hypophyso-gonadal axis may be another common feature. Abnormal onset of puberty was observed in three Myhre patients; among LAPS patients, one had precocious puberty, three had irregular menses, and one secondary amenorrhoea. Progressive laryngotracheal stenosis apparently clearly distinguishes LAPS syndrome from Myhre syndrome, but this could perhaps be explained by insufficient follow up, as the older Myhre patient was only aged 24 whereas onset of obstructive symptoms was between 17 and 30 in LAPS cases. Despite these similarities, some major differences exist. The impressive muscular hypertrophy, which is a cardinal feature of Myhre syndrome, was never reported in LAPS patients. Finally, the sex ratio is strikingly dissimilar, 11 M:0 F in Myhre versus $1 \mathrm{M}: 4 \mathrm{~F}$ in LAPS. These two latter arguments make lumping of LAPS and Myhre hazardous at this point. Further reports and longer follow up of Myhre cases would probably help to solve this nosological issue in the future.

The pattern of inheritance of Myhre syndrome remains unknown. All reported patients were sporadic and paternal age was increased in half of the cases (7/11) suggesting dominant new mutations. However all cases have been males (11/ 11 ) and $X$ linked transmission cannot be excluded to date.

\section{Authors' affiliations}

L Burglen, Unité de Génétique Médicale, Service de Neuropédiatrie, Hôpital Trousseau, AP-HP, Paris, France

D Héron, A Moerman, Département de Génétique Médicale, Hôpital de la Pitié-Salpétrière, AP-HP, Paris, France

A Moerman, A Dieux-Coeslier, S Manouvrier, Département de Génétique Médicale, Hôpital Jeanne de Flandre, Lille, France J-P Bourguignon, University Department of Paediatrics, Liège University, Liege, Belgium

A Bachy, Department of Paediatrics, Clinique Notre Dame, Charleroi,
Belgium

J-C Carel, Service d'Endocrinologie Pédiatrique, Hôpital Saint Vincent de Paul, AP-HP, Paris, France

V Cormier-Daire, Département de Génétique Médicale, Hôpital Necker-Enfants Malades, AP-HP, Paris, France

A Verloes, Unité de Génétique Clinique, Hôpital Robert Debré, AP-HP \& INSERM E9935, Paris, France

Correspondence to: $\operatorname{Dr} A$ Verloes, Unité de Génétique Clinique, Hôpital Robert Debré \& INSERM E9935, Paris, France;

alain.verloes@rdb.ap-hop-paris.fr

\section{REFERENCES}

1 Myhre SA, Ruvalcaba HA, Graham CB. A new growth deficiency syndrome. Clin Genet 1981;20:1-5.

2 Soljak MA, Aftimos S, Gluckman PD. A new syndrome of short stature, joint limitation and muscle hypertrophy. Clin Genet 1983;23:441-6.

3 Garcia-Cruz D, Figuera LE, Feria-Velasco A, Sanchez-Corona J, Garcia-Cruz MO, Ramirez-Duenas RM, Hernandez-Cordova A, Ruiz MX Bitar-Alatorre MO, Cantù JM. The Myhre syndrome: report of two cases. Clin Genet 1993;44:203-7.

4 Whiteford ML, Doig WB, Raine PAM, Hollman AS, Tolmie JL. A new case of Myhre syndrome. Clin Dysmorphol 2001;10:135-40.

5 Titomanlio L, Marzano MG, Rossi E, D'Armiento M, De Brasi D, Vega GR, Andreucci MV, Orsini AVM, Santoro L and Sebastio G. 2001. Case of Myhre Syndrome with autism and peculiar skin histological findings. Am J Med Genet 2001;103:163-5.

6 Giedion A, Brandner M, Lecannellier J, Muhar U, Prader A, Sulzer J Zweymuller E. Oto-spondylo-megaepiphyseal dysplasia (OSMED). Helv Paediatr Acta 1982;37:361-80.

7 Verloes A, Delfortrie J, Lambotte C. GOMBO syndrome of growth retardation, ocular abnormalities, microcephaly, brachydactyly, and oligophrenia: a possible "new" recessively inherited MCA/MR syndrome. Am J Med Genet 1989:32:15-18.

8 Bottani A, Verloes A. Myhre-GOMBO syndrome: possible lumping of two "old" new syndromes. Am J Med Genet 1995;59:523-24.

9 Verloes A, Lesenfants S, Jamar M, Dideberg V, Herens C. GOMBO syndrome: another "pseudorecessive" disorder due to a cryptic translocation. Am J Med Genet 2000;95:185-6.

10 Moore WT, Federman DD. Familial dwarfism and "stiff joints": report of a kindred. Arch Intern Med 1965;1 15:398-404

11 Maroteaux P, Stanescu R, Stanescu V, Rappaport R. Acromicric dysplasia. Am J Med Genet 1986;24:447-59.

12 Faivre L, Le Merrer M, Baumann C, Polak M, Chatelain P, Sulmont V, Cousin J, Bost M, Cordier MP, Zackai E, Russell K, Finidori G, Pouliquen JC, Munnich A, Maroteaux P, Cormier-Daire V. Acromicric dysplasia: long term outcome and evidence of autosomal dominant inheritance. $J$ Med Genet 2001;38:745-9.

13 Spranger J, Gilbert EF, Arya S, Hoganson GMI, Opitz JM. Geleophysic dysplasia. Am J Med Genet 1984;19:501-6.

14 Pontz BF, Stoss H, Henschke F, Freisinger P, Karbowski A, Spranger J. Clinical and ultrastructural findings in three patients with geleophysic dysplasia. Am J Med Genet 1996;63:50-4.

15 Hopkin RJ, Cotton R, Langer LO, and Saal HM. Progressive laryngotracheal stenosis with short stature and arthropathy. Am J Med Genet 1998;80:241-6.

16 Lindor NM, Kasperbaver JL, Hoffman AD, Parisi JE, Wang H, Warman $M$. Confirmation of existence of a new syndrome: LAPS syndrome. Am J Med Genet 2002:109:93-9.

17 Winter RM, Patton MA, Challener J, Mueller RF, Baraitser M. Moore-Federman syndrome and acromicric dysplasia: are they the same entity? J Med Genet 1989;26:320-5

18 Hennekam RC, van Bever Y, Oorthuys JW. Acromicric dysplasia and geleophysic dysplasia: similarities and differences. Eur J Pediatr 1996;131:311-14.

19 Figuera LE. Geleophysic dysplasia vs Myhre syndrome. Am J Med Genet 1996;65:361.

20 McGaughran JM, Donnai D. Geleophysic dysplasia and Myhre syndrome. Am J Med Genet 1996;65:362. 